\title{
Effects of ovulation of aged follicles, pregnancy diagnosis by ultrasonography, and treatments during lactation on reproduction in ewes
}

\author{
Aimee Kathryn Wurst \\ West Virginia University
}

Follow this and additional works at: https://researchrepository.wvu.edu/etd

\section{Recommended Citation}

Wurst, Aimee Kathryn, "Effects of ovulation of aged follicles, pregnancy diagnosis by ultrasonography, and treatments during lactation on reproduction in ewes" (2007). Graduate Theses, Dissertations, and Problem Reports. 4350.

https://researchrepository.wvu.edu/etd/4350

This Dissertation is protected by copyright and/or related rights. It has been brought to you by the The Research Repository @ WVU with permission from the rights-holder(s). You are free to use this Dissertation in any way that is permitted by the copyright and related rights legislation that applies to your use. For other uses you must obtain permission from the rights-holder(s) directly, unless additional rights are indicated by a Creative Commons license in the record and/ or on the work itself. This Dissertation has been accepted for inclusion in WVU Graduate Theses, Dissertations, and Problem Reports collection by an authorized administrator of The Research Repository @ WVU.

For more information, please contact researchrepository@mail.wvu.edu. 
EFFECTS OF OVULATION OF AGED FOLLICLES, PREGNANCY DIAGNOSIS BY ULTRASONOGRAPHY, AND TREATMENTS DURING LACTATION ON REPRODUCTION IN EWES

\author{
Aimee Kathryn Wurst
}

Dissertation submitted to the Davis College of Agriculture, Forestry, and Consumer Sciences at West Virginia University in partial fulfillment of the requirements for the degree of

\author{
Doctor of Philosophy \\ in \\ Reproductive Physiology
}

E. Keith Inskeep, Ph.D., Chair

Robert A. Dailey, Ph.D.

Jorge A. Flores, Ph.D.

Paul Lewis, Ph.D.

William E. Vinson, Ph.D.

Faculty of Reproductive Physiology

Morgantown, WV

2007

Keywords: Pregnancy Loss, Ewe, Ovarian Follicle, Lactation, Ultrasonography 


\begin{abstract}
Effects of Ovulation of Aged Follicles, Pregnancy Diagnosis by Ultrasonography, and Treatments During Lactation on Reproduction in Ewes
\end{abstract}

Aimee K. Wurst

\begin{abstract}
Ewes are polyestrous and litter-bearing seasonal breeders. Although average ovulation rates are sufficient, many ovulations do not result in live offspring and ewes normally breed only once per year. As ovulation rate increases, so does the number of ovulations not represented by live births. When ultrasonographic analysis is limited to ovarian follicles that grow from 3 to $5 \mathrm{~mm}$, follicular waves can be identified in sheep. In most cases, ovulatory follicle(s) develop from the ultimate follicular wave; however, ovulatory follicles can be derived from penultimate or earlier follicular waves. The relationship between lifespan of large follicles and fertility is controversial in sheep. In experiment 1 , three approaches to create a model to compare fertility when ovulatory follicles developed from only the ultimate follicular wave or both ultimate and penultimate waves were tested. Ewes were treated on d 10 or 11 with $50 \mu g$ of $\mathrm{GnRH}$ i.m.,
\end{abstract} the largest follicle(s) $(\geq 4 \mathrm{~mm})$ on each ovary were electrocauterized, or ewes were treated with $50 \mu \mathrm{g}$ estradiol benzoate and $50 \mathrm{mg}$ progesterone or $100 \mu \mathrm{g}$ estradiol benzoate and $50 \mathrm{mg}$ progesterone in attempts to induce follicular regression or luteinization. Corpora lutea were counted by ultrasound 7 days following estrus in order to verify ovulation of follicles that disappeared post estrus. Pregnancy was determined and embryos were counted 20 to 30 days following estrus. Neither treatment with $\mathrm{GnRH}$ nor estradiol and progesterone consistently caused regression or luteinization of ovulatory-sized follicles. Follicular ablation was successful in increasing the proportion of ovulations originating from the ultimate follicular wave in Dorset/Suffolk cross ewes, but did not alter the proportions of ovulations fom different waves in Polypay ewes. Average age of the ovulatory follicle was affected only in Dorset/Suffolk cross ewes. Due to lack of treatment effects, ovulatory follicles were evaluated regardless of treatment for effects on embryonic or fetal losses. Although loss tended to differ among follicular age combinations and wave sources of ovulatory follicles within ewes, older follicles did not have worse outcomes than younger follicles.

Lactating ewes have not responded to treatments for the induction of estrus that are effective in dry ewes during the anestrous season. In experiment 2, lactating anestrous ewes 26 to 71 days postpartum were treated with either 25 or $50 \mathrm{mg}$ progesterone/day for five days before ram introduction (RI). Twelve hours after RI, lambs were removed from half of the ewes in each group for 72 hours. Estrous response was recorded and ewes were scanned by transrectal ultrasonography on days 8 and 35 to 45 to determine ovulation rate, and pregnancy rate and number of embryos/fetuses, respectively. Number of lambs born was recorded at lambing. No effect of lamb removal was found for any variable examined. However, the lower dosage of progesterone reduced the mean time to estrus, increased the proportion of ewes ovulating, and decreased 
pregnancy loss. Overall, temporary lamb removal did not improve the response of lactating ewes to induction of estrus in the anestrous season.

Whether ultrasonography itself causes embryonic or fetal loss was addressed in experiment 3 . Ten flocks bred in either the estrous or anestrous season were randomized into control or examined groups within flock. Examined ewes were placed in a tilting squeeze chute and scanned for pregnancy by transrectal ultrasonography once between days 25 and 100 post-breeding. Control ewes were not subjected to handling in the squeeze chute or pregnancy diagnosis. Lambing rate and numbers of lambs born were recorded for all ewes. Examined ewes had similar pregnancy and lambing rates to control ewes and slightly greater prolificacy in the same flocks. Based on these data, the combination of transrectal ultrasonography with restraint is safe for pregnancy diagnosis in ewes. Cumulatively, these experiments help to address the question of what factors are associated with embryonic and fetal losses in ewes and how sheep producers may increase the number of lambs born per ewe by increasing either ovulation rate or the number of pregnancies per ewe per year. 


\section{ACKNOWLEDGEMENTS}

Many people were involved in making this work possible. First and foremost, I would like to thank my mentor, Dr. E. Keith Inskeep, for his patient guidance and example. His excellence in research combined with integrity and an incredible work ethic has truly been an inspiration to me over the past five years. I would like to thank Dr. Robert Dailey for his help and advice on matters of science, teaching, ethics, and life. His words of wisdom have always been appreciated and will not be forgotten. Special thanks to Drs. Jorge Flores, Paul Lewis, William Vinson, and Marlon Knights for their assistance and input on my graduate committee. Also, thanks to Dr. Vasantha Padmanabhan for including me in her exciting research at the University of Michigan.

Many others have helped me in various aspects of my life and work in West Virginia. I would like to thank Dr. Robert Pitts for his help on issues concerning animal care and for his advice on graduate school. I would like to thank Karie Hardy, who spent many hours helping me to treat sick animals, but more importantly, for her unwavering friendship. Thanks to Dr. Eugene Felton and Jianbo Yao for their assistance in my research and their help on job applications. Thanks to Dr. Fred Stormshak who has remained a mentor and friend even after I left Oregon State University and was the reason why I came to West Virginia. His advice and support over the years have been invaluable.

Thanks to Brad Smith who volunteered to assist me in my research at the U.S. Sheep Experiment Station. Also, thanks to Drs. Greg Lewis and Shiquan Wang for allowing me to use sheep at the U.S. Sheep Experiment Station on my studies and helping me to set up experiments. Thanks to John Stellflug for his help and for allowing me to stay with his family while I was in Idaho. Thanks to the farm crews at Reymann Memorial Farm and the WVU Morgantown Farm, especially to Vernon Wilkons, for their assistance in animal management.

These experiments would not have been possible without the sheep producers I have had the opportunity to work with along the way who graciously gave of their time, labor, and animals for experiments. Special thanks go to the families of Mark Teets, Jeff Lawson, Marvin Warner, Jim Dean, Jeff Harsh, and Danny Teter for allowing use of their animals on our experiments and for feeding us many great meals along the way.

I have had the pleasure of working with many great graduate students over the years. Special thanks to Mindy Washko, Jamie Wentz, Matthew Dean, Ida Holaskova, Fredrick Othiambo, Justin Rhinehart, Pam Sutton, Daniel Poole, Brandon Lingenfelter, Ezra Devonish, Nancy Kerr, Fernando Perea, Melanie Starbuck, Alison Dixon, Tina Dow, Laura Pfeifer, and Jamie Kinsey for their assistance and friendship. Many undergraduate workers and volunteers have also helped me along the way. Thanks to Amy Anderson, Gail Nesselrod, Bud Nesselrod, Jonathan Taylor, Ben Wilfong, Julie Dawson, Kevin White, Stacey Hamric, Stevie Braun, and many others. I could not have done my research without them and thank them for the many days and nights of hard work.

Last, but not least, I would like to thank my parents, David and Taube Wurst, and my sister, Megan, for their love and support. I would not have had the courage to accomplish what I have without their advice and encouragement. 


\section{TABLE OF CONTENTS}

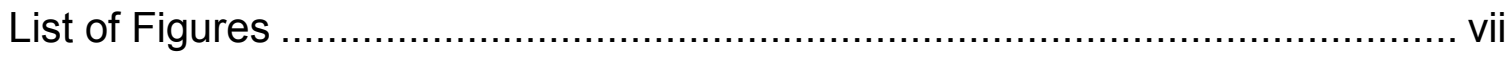

List of Tables ...................................................................................... vii

CHAPTER 1: EFFECTS OF AGED FOLLICLES ON FERTILITY IN EWES .........1

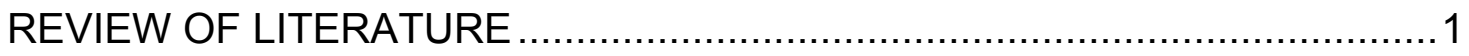

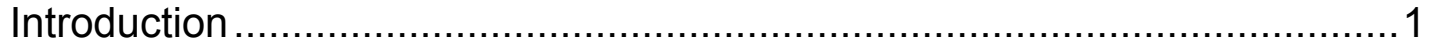

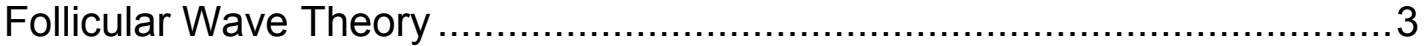

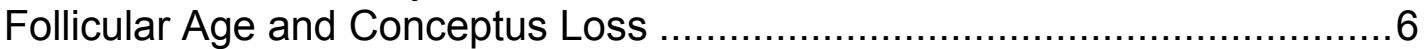

Hormonal Factors Influencing Follicular Dynamics ................................... 8

Manipulation of Follicular Growth......................................................22

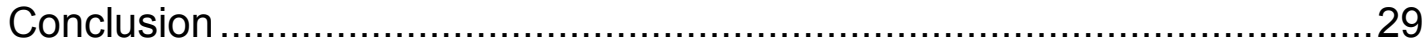

STATEMENT OF THE PROBLEM ............................................................

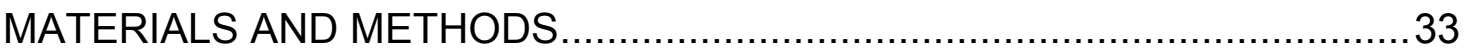

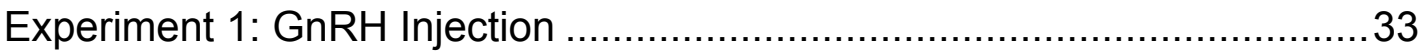

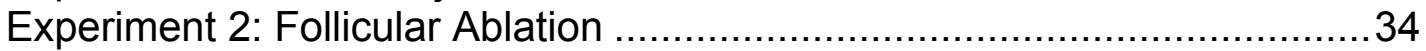

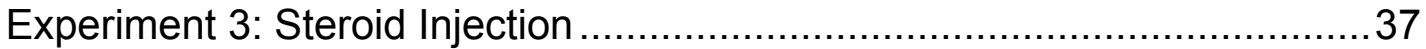

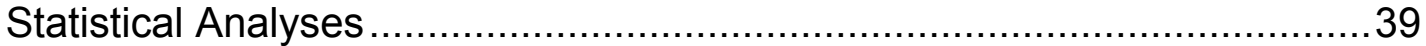

Analyses of Ovulation Data Across Experiments ......................................40

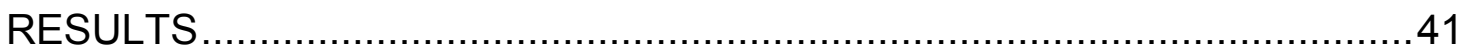

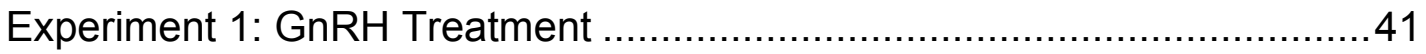

Experiment 2: Follicular Ablation by Surgery …….............................43

Experiment 3: Steroid Treatment ..................................................4 44

Analyses of Ovulation Data Across Experiments .....................................45

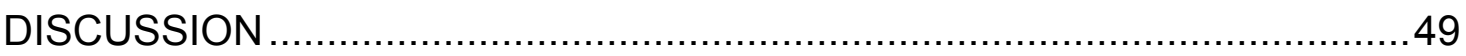

CHAPTER 2: EFFECTS OF EXOGENOUS PROGESTERONE AND LAMB REMOVAL ON ESTROUS RESPONSE AND FERTILIITY IN LACTATING

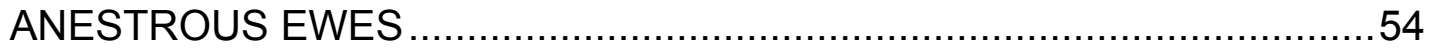

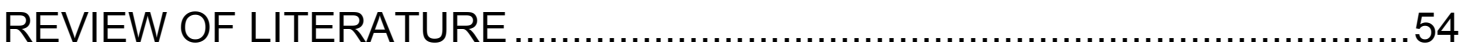

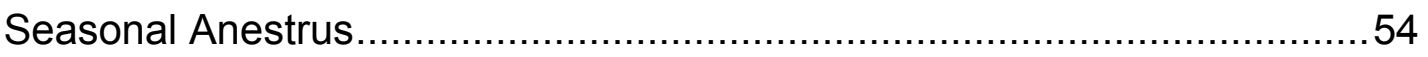

Postpartum Anestrus .................................................................. 56

Methods of Estrous Synchronization in Lactating Anestrous Ewes .............60

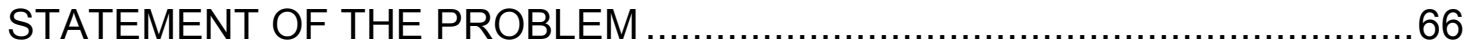

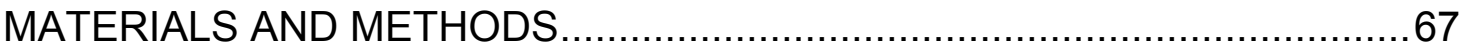

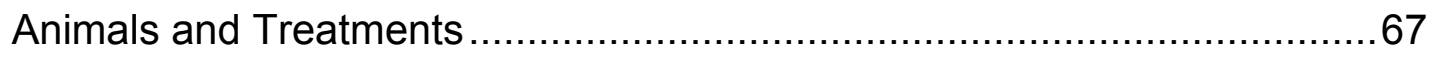

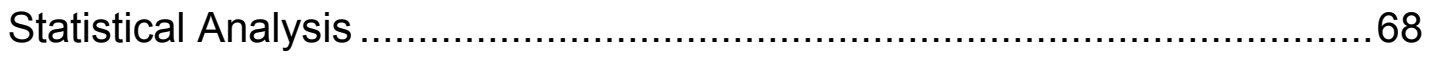

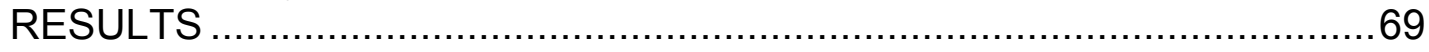

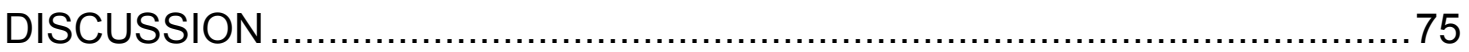




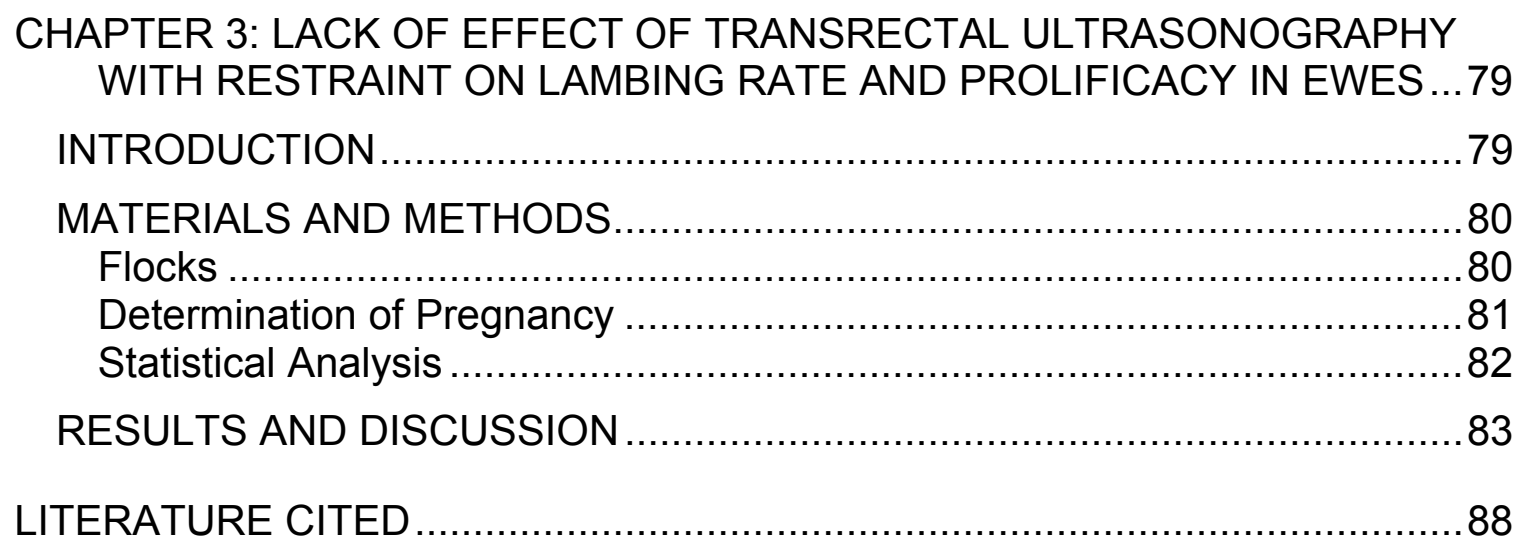




\section{LIST OF FIGURES}

Figure 1: Potential factors affecting late embryonic or fetal survival in ewes. ......2

Figure 2: Effect of GnRH on follicular atresia. Treatment with $50 \mu \mathrm{g}$ of $\mathrm{GnRH}$ did not alter proportion of penultimiate follicles $\geq 4 \mathrm{~mm}$ that became atretic within two days of treatment.

Figure 3: Effect of treatment on percentages of ovulations from different wave sources. Treatment with $50 \mu \mathrm{g}$ of $\mathrm{GnRH}$ did not affect the source of ovulatory follicles. 


\section{LIST OF TABLES}

Table 1: Follicular age categories based on days mapped on the ovary from $\geq 2$ mm until ovulation by location............................................................46

Table 2: Association of embryonic or fetal loss by ewes with age category of ovulatory follicle(s) $(\mathrm{P}>0.10)$.

Table 3: Association of embryonic or fetal loss by ewes with specific age categories of combinations of ovulatory follicle(s) $(P=0.07)$.

Table 4: Percent of ovulations from follicular wave sources (ultimate $(U)$ and/or penultimate or earlier $(P))$ for ewes scanned by transrectal ultrasonography by location

Table 5: Association of categories of ovulations from follicular wave sources (ultimate $(U)$ and/or penultimate or earlier $(P)$ ) for ewes scanned by transrectal ultrasonography with embryonic or fetal loss.

Table 6: Variables affecting estrous response from progesterone treatment and ram introduction $(\mathrm{RI})$ in lactating anestrous ewes.

Table 7: Variables affecting proportion of ewes with $C L$ at seven days following ram introduction

Table 8: Variables affecting proportion of ewes pregnant at pregnancy diagnosis between days 20 to 30 after estrus.

Table 9: Variables affecting the proportion of ewes losing pregnancy of ewes diagnosed pregnant and the proportion of ewes lambing of ewes treated...74

Table 10: Summary of values and means within flocks for examined ewes (E; undergoing restraint and transrectal ultrasonography) and control ewes (C). 


\section{CHAPTER 1: EFFECTS OF AGED FOLLICLES ON FERTILITY IN EWES}

\section{REVIEW OF LITERATURE}

\section{Introduction}

Embryonic and fetal mortality are large sources of economic loss in the livestock industry. Although average ovulation rates are sufficient, a significant economic loss results from a large percentage of those oocytes not resulting in live offspring. As reviewed by Dixon (2003), quality of semen, quality of ova and uterine environment, and the embryo itself play roles in embryonic and fetal loss in the ewe. Other environmental factors, both internal, such as uterine physiology and hormonal secretions, and external, such as ambient temperature, nutrition, and disease, can influence late embryonic or fetal survival (see Fig. 1).

Embryonic and fetal losses were estimated to be approximately $30 \%$ when number of offspring born was compared to number of corpora lutea (Bolet, 1986). Fertilization failure tends to be very low, accounting for 5 to $10 \%$ of total potential offspring (Quinlivan et al., 1966; Restall and Griffiths, 1976; Long and Williams, 1980; Armstrong et al., 1983). In early work, the greatest amount of loss in the ewe occurred before day 18 of gestation and accounted for the majority of total loss (Hulet et al., 1956; Moore and Rowson, 1960; Quinlivan et al., 1966). However, Dixon et al. (2007) found via ultrasonographic imaging that embryonic/fetal losses in the ewe were relatively linear throughout gestation with approximately 3 to $4 \%$ of potential offspring lost for each 20 -day period of pregnancy beyond day 25. Further, partial pregnancy losses (individual embryos or fetuses lost without loss of the pregnancy) were more frequent than complete 
losses, which means that lambing rates were usually lower than ovulation rates in ewes.

As ovulation rate increased, so did the number of ovulations not represented by live offspring at lambing (Rhind et al., 1980a, b; Meyer, 1985; Bradford et al., 1986; Dixon et al., 2007). Rhind et al. (1980a) found that the proportion of ovulations represented by viable fetuses on day 60 or 145 of gestation was inversely related to ovulation rate. This was found also when ovulation rate was increased by the use of gonadotropins (Robinson, 1951; Bindon et al., 1971; Knights et al., 2003). In very prolific breeds of sheep, litter size peaked at approximately five ovulations (Hanrahan, 1976; Rhind et al., 1980a, b; Piper and Bindon, 1981).

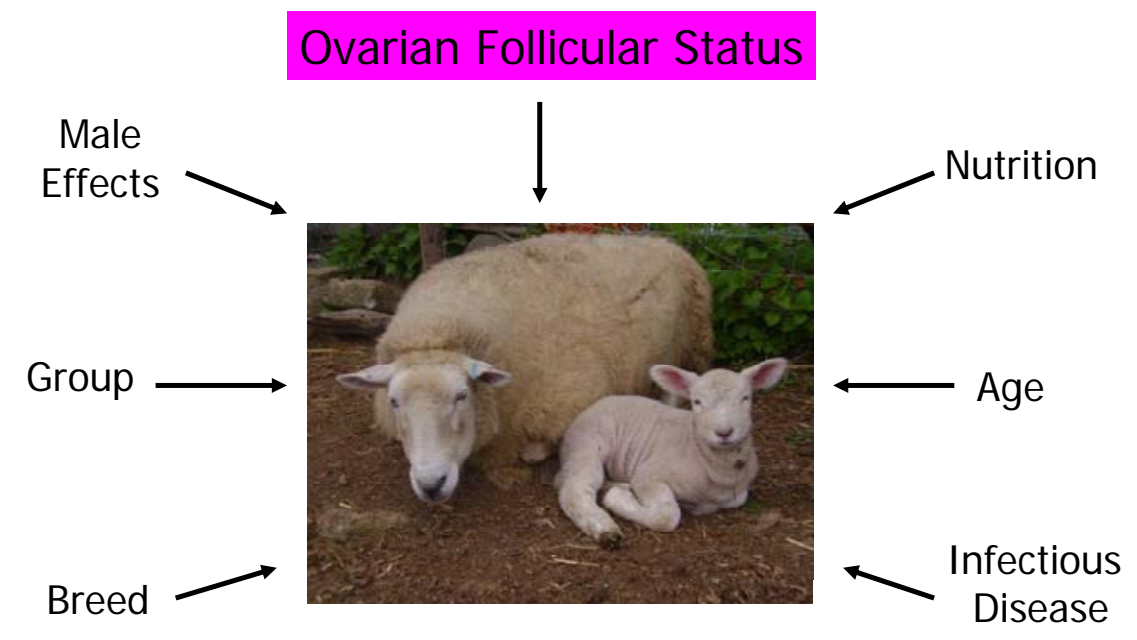

Figure 1: Potential factors affecting late embryonic or fetal survival in ewes. 
This review will examine relationships between follicular development and embryonic and fetal losses in ewes, with particular attention to age of follicle on the ovary. The relationship of embryonic loss to age of follicle has been wellcharacterized in the cow. Thus, references to the cow will be utilized to establish similarities and differences in follicular development, ovulation, and embryonic and fetal losses between sheep and cattle, to help characterize what is occurring in the ewe.

\section{Follicular Wave Theory}

Cole (1933) studied serial sections from ovaries of ewes and cows and found no signs of cyclical variations in follicular growth, maturity, or atresia. Kammlade et al. (1952) noted that although there appeared to be no relation between the number of follicles and the stage in the cycle of ewes, the regression of mean follicular diameter on day of cycle was highly significant. In 1960, Rajakoski began using the term "follicle wave" in order to describe the uneven pattern of distribution of medium to large follicles on the ovaries of heifers collected at slaughter. He noted that numbers of follicles $\geq 5 \mathrm{~mm}$ in diameter were organized into two distinct growth periods, which he termed "waves" of growth. Using daily ultrasonography on the same animals, Pierson and Ginther (1988), Savio et al. (1988), and Sirois and Fortune (1988) verified the wave-like pattern of follicular growth in cattle.

Schrick et al. (1993) and Lopez-Sebastian et al. (1997), using transrectal ultrasonography, noted that patterns of growth and regression of individual follicles indicated a relatively constant number of follicles available for ovulation 
in each ewe. Ginther et al. (1995) found that follicles in cyclic Polypay ewes that reached only 3 or $4 \mathrm{~mm}$ in diameter did not exhibit an organized pattern of growth and demise. However, some $3 \mathrm{~mm}$ follicles began to grow to $\geq 5 \mathrm{~mm}$ approximately every five days during the interovulatory interval. A follicular wave is considered to consist of the initial synchronous growth of a cohort of follicles (emergence), followed by one or more that continue(s) growing (the "dominant" follicle(s)) while others regress (subordinate follicles; Evans, 2003). When only follicles that reached $\geq 5 \mathrm{~mm}$ in diameter were considered, apparent waves of follicular growth were demonstrated in sheep. In ewes, a follicular wave generally consists of one to three follicles growing from 2 to $3 \mathrm{~mm}$ to a maximum size of usually 4 to $7 \mathrm{~mm}$ in diameter before regression or ovulation (Duggavathi et al., 2003), with follicular emergence generally restricted to a 24 - to 48 -hour period. In different breeds of sheep that showed waves of follicular growth, two to four waves per cycle were detected (reviewed by Duggavathi et al., 2003). Finn and Western white-faced (Bartlewski et al., 1999) and Polypay (Ginther et al., 1995) ewes typically had four waves of large antral follicular growth, while Suffolk ewes had two or three waves (Noel et al., 1993; Ravindra et al., 1994). In Polypay ewes, sequential follicular waves emerged on mean days $0,5,9$, and 14 of the estrous cycle (Ginther et al., 1995). "Western white-faced" ewes had waves that emerged on mean days $0,5,9$, and 12 of the estrous cycle, while Finn sheep had wave emergence on days 1, 6, 10, and 13 (Bartlewski et al., 1999). As the duration of the ovine estrous cycle in the breeding season is normally $17 \pm 1$ days and there is little effect of breed and age (Hafez, 1952), 
these mean days of waves of follicular emergence should be similar in most breeds when consideration is limited to follicles reaching $\geq 5 \mathrm{~mm}$.

\section{Source of Ovulatory Follicles}

Most ovulatory follicles develop from the last follicular wave. However, ovulatory follicles also can come from the penultimate follicular wave (Bartlewski et al., 1999; Gibbons et al., 1999), giving rise to a situation in which follicles of different ages ovulate during a single estrus.

Driancourt et al. (1986) found no association between ovulation rate and the overall number of antral follicles available in prolific breeds of sheep (Romanov, Finn, and Booroola Romanov crosses). However, decreased atresia and a prolonged recruitment phase were common mechanisms among these breeds. Thus, some ovulatory follicles might have been recruited from the penultimate or earlier waves of follicular growth, which means that increased ovulation rate could be due to a wider window of time for follicular recruitment or during which follicles were responsive to an LH surge (Driancourt et al., 1986; Scaramuzzi et al., 1993).

The proportion of ovulatory follicles from the penultimate wave in Finn sheep was $50 \%$, and when combined with follicles from the ultimate wave, gave a higher ovulation rate compared with Western white-faced ewes that did not have ovulatory follicles from the penultimate wave (Bartlewski et al, 1999). In Finn sheep, the ovulatory follicles originating from the penultimate wave emerged approximately 48 hours later than non-ovulatory follicles in the same wave 
(Bartlewski et al., 1999). Those authors proposed that regression of those follicles was prevented by the next increase in serum concentrations of FSH.

\section{Follicular Age and Conceptus Loss}

The relationship between follicular lifespan and fertility has been well documented for cattle. Breuel et al. (1993) found that cows with larger (presumably older) dominant follicles five days before the surge of LH had greater preovulatory concentrations of estradiol and a lower conception rate $(36 \%)$ than cows with smaller follicles at that time (91\% conception). When follicular dominance was prolonged more than eight days in cows, a reduction in follicular and oocyte health occurred (Mihm et al., 1994; Ahmad et al., 1995). Although ovulatory and fertilization capabilities were maintained, the ability of embryos to reach the 16-cell stage was compromised and early embryonic death occurred (Wishart, 1977; Ahmad et al., 1995; Mihm et al., 1999). Conception rate to first service was reduced in dairy cows that ovulated from the second $(63 \%)$ versus the third $(81 \%)$ wave of follicular development; the dominant follicle from the second wave was approximately 1.5 days older (Townson et al., 2002). Further, Bleach et al. (2004) found an inverse relationship between interval from ovulatory follicle emergence to estrus and proportion of dairy cows diagnosed pregnant from artificial insemination. Mean interval from ovulatory follicle emergence to estrus was one day shorter in cows diagnosed pregnant compared to those diagnosed non-pregnant.

A 48-hour delay in ovulation decreased implantation rate, retarded embryonic growth, and increased embryonic death in rats (Butcher and Pope, 
1979). Most experimental results from the delayed ovulation of rats indicated that retention of the oocyte in a developing follicle past its normal time of ovulation produced a variety of deleterious effects, which might be manifested at any time from ovulation to the birth of an abnormal offspring (Butcher, 1972). Similarly, Dixon (2007) found that embryos and fetuses were lost throughout pregnancy in the ewe, especially partial losses of multiple pregnancies, which leads one to suggest that similar causes of loss may exist in sheep.

\section{Oocyte Quality}

Among oocytes collected from small to medium sized follicles in cattle, sheep, or goat ovaries at an abbatoir, more than $90 \%$ reached metaphase II of meiosis after in vitro maturation (IVM), and more than $70 \%$ were fertilized, but only one-third developed to the morula-blastocyst stage after in vitro development (reviewed in Mermillod et al.,1999). As developmental competence of oocytes increases during folliculogenesis, oocytes collected from a heterogeneous follicular population displayed differential abilities to become normal embryos due to differences in their acquired development. In many species, when follicles were dissected and classified by size, oocytes from larger follicles provided better developmental results than those from smaller follicles (e.g. Cognié et al., 1998).

In vivo, the follicular environment could regulate cytoplasmic maturation. Moor et al. (1996) showed that the first 6 hours spent by the oocyte inside the LH-stimulated follicle in sheep are important for its developmental competence. Follicular fluid used as a supplement in maturation medium is a potent activator 
of oocyte maturation. Although this effect seems to be independent of follicular size, it is influenced by the stage of atresia in both sheep and cattle (Cognié et al., 1995; Carolan et al., 1996).

Although some of the events related to oocyte capacitation and maturation are known, little is known about markers of the completion of developmental competence of the oocyte except for actually tracking their progression into normal embryos. Morphological evaluation of the cumulus-oocyte complex may indicate improper maturation, but this is not sufficient to predict developmental potential (reviewed in Mermillod et al., 1999). Further, maturation past the prime stage for development is possible, so there is a possibility for an oocyte to be either too mature or too immature (reviewed by Inskeep, 2004). Thus, the idea of oocyte quality is important but, currently, is only an indirectly measurable component of reproductive success.

\section{Hormonal Factors Influencing Follicular Dynamics}

\section{FSH}

In addition to the peak of $\mathrm{FSH}$ secretion coincident with the preovulatory surge of LH and a secondary surge commencing 18 to 24 hours later, fluctuating concentrations of $\mathrm{FSH}$ in plasma have been measured during the ovine estrous cycle (see Findlay, 1994). Measurements of the metabolic clearance rate of FSH in sheep (Akbar et al., 1974; Findlay and Cumming, 1976) supported the notion that these changes in the peripheral concentrations of $\mathrm{FSH}$ were due to changes in pituitary secretion and not removal of FSH from the blood. Although failing to show a consistent relationship between ovulation rate and circulating 
concentrations of FSH (Findlay and Cumming, 1976), these early studies proved that follicles on the ovary could be stimulated by FSH secretion.

During growth of a cohort of follicles, FSH begins to decline and reaches nadir near the time of deviation (one follicle continues to grow while others regress) in horses and cattle (Gastal et al., 1997; Ginther et al., 1998). This decrease in $\mathrm{FSH}$ concentration has been identified as a key component of the selection process, because administration of FSH during the common growth phase of the wave in cattle (Mihm et al., 1997) and horses (Rosas et al., 1998) prevented deviation and allowed development of multiple dominant follicles. The high spontaneous co-dominance and multiple ovulation rate observed in lactating dairy cows provided an opportunity to evaluate the hormonal profiles associated with follicular selection, because co-dominance represents a natural aberration in the follicular deviation process (Lopez et al., 2005). Heifers and cows with double or triple dominant follicles tended to have greater circulating FSH before deviation and no difference or lower circulating FSH after deviation than cows with only one dominant follicle (Kulick et al., 2001; Lopez et al., 2005). Interestingly, Lopez et al. (2005) found that cows displaying three dominant follicles had even greater concentrations of FSH than those with co-dominant follicles for the 24 hours before deviation.

In different breeds of sheep, each follicular wave was preceded by a transient increase in serum concentrations of FSH (Duggavathi et al., 2003). However, Scaramuzzi and Radford (1983) found no difference in FSH concentration between Booroola and Merino ewes with single versus twin ovulations on days 2, 9, and 16 of the estrous cycle. Further, plasma 
concentrations of FSH during the preovulatory period in the less prolific Galway sheep were greater than in more prolific Finnish Landrace ewes (Adams et al., 1988). Possibly, follicular responsiveness to the gonadotropins is increased in ewes carrying the Booroola mutation (reviewed by Montgomery et al., 1992).

Duggavathi et al. (2005) studied the effect of giving exogenous FSH either at the time of expected FSH peaks or at the time of expected nadirs between two peaks. Doubling the FSH peak amplitude at the time of a peak had no effect on follicular dynamics. Increasing the frequency of FSH peaks stimulated the emergence of additional follicular waves, but did not alter the endogenous occurrence of FSH peaks and follicular wave emergence. Therefore, the authors speculated that although follicular growth was dependent on FSH secretion, endogenous FSH was not regulated by follicular growth. These results were in agreement with the study of Barrett et al. (2006) that showed that even after truncation of follicular wave emergence by estradiol implants, treatment with exogenous FSH could reinitiate follicular wave emergence.

\section{LH}

It has been reported that $\mathrm{LH}$ has a role in the growth and function of the largest follicles after the beginning of follicle deviation (Ginther et al., 2001b). Both cattle (Ginther et al., 2001b; Bergfelt et al., 2000; Lopez et al., 2005) and horses (Gastal et al., 1997) showed a transient increase in LH concentrations surrounding the time of deviation. It has been postulated that this increase in $\mathrm{LH}$ might be involved in deviation, because LH is known to stimulate the production of estradiol and insulin-like growth factor-I (Ginther et al., 2001a, b). Luteinizing 
hormone pulse frequency during this period is reduced by an increased concentration of circulating progesterone (Adams et al., 1992).

At ovulation, a slight delay in the occurrence of the LH surge has been described in prolific breeds of sheep such as the Romanov (Land et al., 1973). Bindon et al. (1979) observed a positive relationship between the number of corpora lutea and the time from luteolysis to the LH rise in prolific ewes. In cattle, when the LH surge was delayed by approximately 12 to 15 hours, ovulation rate and embryo recovery were increased. Therefore, it was suggested that some preovulatory follicles did not have adequate time to complete normal maturation prior to the LH surge (reviewed in D'Occhio et al., 1999). In ewes superovulated with purified $\mathrm{FSH}$, the rate of embryo recovery was lower in those ewes with earlier preovulatory LH peaks when compared to ewes showing a longer interval between estrus and the LH peak (Gonzalez-Bulnes et al., 2002).

When superovulated heifers were given a $\mathrm{GnRH}$ antagonist to delay the LH surge, number of transferable embryos was decreased (Madill et al., 1994). In contrast, Oussaid, Lonergan and Mermillod (unpublished data, reviewed in Mermillod et al., 1999) used a similar approach on superovulated heifers and retrieved oocytes from all follicles $>5 \mathrm{~mm}$ present on the ovarian surface 24,36 , or 60 hours after the last FSH injection. Maintenance of preovulatory follicles for more than 24 hours was detrimental to follicular health (indicated by markers of atresia); however, developmental potential of the oocytes and quality of the resulting embryos were not affected.

In ewes, the interval from estrus to the LH surge varies between and within breeds, and is generally shorter in ewes with one ovulation than in those 
with two (Thimonier and Pelletier, 1971). Suppression of LH pulses using a $\mathrm{GnRH}$ antagonist one day before ovulation decreased plasma concentrations of estradiol and caused inferior embryonic development (Oussaid et al., 1999). In comparing fertility measures of the Belclare and Suffolk ewe breeds, Fair et al. (2006) found no effect of ewe breed on cleavage rate of oocytes matured and fertilized in vitro or in vivo, or on percentage of cleaved embryos developing to the blastocyst stage for in vitro or in vivo matured and fertilized oocytes. They speculated that because the interval from pessary removal to the LH surge was significantly shorter (by an average of 3.4 hours; Fair et al., published in 2007) in Suffolk than in Belclare ewes, decreased fertilization rate and embryonic development in Suffolk ewes following cervical Al could be due to differences in oocyte quality (Fair et al., 2005). However, in another study (Fair et al., 2006), they found no effect of ewe breed on cleavage rate of oocytes matured and fertilized in vitro or in vivo, or on percentage of cleaved embryos developing to the blastocyst stage for in vitro or in vivo matured and fertilized embryos. Therefore, it was concluded that effects of differences in timing of the LH surge did not explain differences in fertility.

\section{Progesterone}

Estrous cycle length and age of the ovulatory follicle are determined via the relationship of LH pulse frequency with concentration of progesterone (reviewed in Inskeep and Dailey, 2005). When concentrations of progesterone were low, high frequency pulses of LH stimulated continued growth of the lead follicle (Taft et al., 1996). Ulberg et al. (1951) recognized the larger size of 
follicles in animals completing treatment with low dosages of progesterone.

Prolonged use (14 to 21 days) of progesterone/progestogens to synchronize estrus reduced fertility at the subsequent estrus in cattle (Pierson and Ginther, 1988). However, shorter intervals of progestogen treatment (8 to 10 days) combined with induced luteolysis at the end of treatment have allowed a fertile estrus (Macmillan and Peterson, 1993; Macmillan and Thatcher, 1991).

Progestogen treatment for seven days (in the absence of a functional $\mathrm{CL}$ ) allowed development of a persistent follicle, and in one study, persistent follicles that developed after a progesterone-impregnated controlled internal drug releasing insert for cattle (CIDR-B®) was in place for nine days, resulted in poor pregnancy rates (Ginther et al., 1989). Further, the feeding of melangestrol acetate (MGA®) for 14 to 17 days effectively synchronized estrus, but lowered fertility (reviewed by Odde, 1990). Feeding MGA for shorter periods (i.e. seven days) restored fertility when feeding was started early in the estrous cycle, but not when MGA was started late in the cycle (Beal et al., 1988). This was probably due to the development of persistent dominant follicles after luteal regression (Custer et al., 1994; Kojima et al., 1995); such follicles are associated with reduced fertility (Patterson et al., 1989; Custer et al., 1994; Ahmad et al., 1995).

Concentrations of progesterone during the luteal phase influenced the persistence of a follicle and the number of follicular waves during an estrous cycle (Richards et al., 1990; Sanchez et al., 1993, 1995; Smith and Stevenson, 1995). The length of the luteal phase appears to be the primary determinant of number of waves, unless very low progesterone leads to persistence of a dominant follicle (discussed in Inskeep, 2004). Oocytes from persistent follicles 
were likely to be at a more advanced stage of maturation than those from follicles of normal age and size (Revah and Butler, 1996; Mihm et al., 1999).

Fertility was reduced when progesterone was low during the natural estrous cycle before breeding (Folman et al., 1973; Meisterling and Dailey, 1987). The ovulatory follicle in cows with two waves of follicular development was older by 1.5 days and larger by $1.2 \mathrm{~mm}$ than the ovulatory follicle in cows with three waves, and progesterone concentrations were significantly lower during days 16 to 20 of the cycle in cows with two waves, probably due to the earlier regression of the CL in these cows (Ahmad et al., 1997). As discussed earlier, conception rate to first service was reduced in dairy cows that ovulated from the second $(63 \%)$ versus the third $(81 \%)$ wave of follicular development during the estrous cycle before insemination, indicating that progesterone concentrations may be related to both age of the ovulatory follicle and conception rate (Townson et al., 2002). Thus, lower progesterone concentrations at the time of growth of the ovulatory follicle are associated with the ovulation of older follicles and decreased fertility.

Taft (1999) reduced circulating progesterone on day 6 of the estrous cycle in cattle and obtained evidence that changes in oocyte maturation began within 48 hours of lowered progesterone (day 8). Those characteristics included advancement of stage of maturity, irregularity of the nuclear membrane, degeneration of cumulus cell processes, and changes in shape and clumping of the mitochondria. Under normal progesterone concentrations, similar changes in oocytes in dominant follicles of the first follicular wave become apparent one day after emergence of the lead follicles of the second wave (day 10). Thus, changes 
characteristic of prematuration were seen during early stages of atresia, and although the oocytes from persistent follicles were fertilized, development from the resulting zygote was retarded and early embryonic death usually occurred before the 16-cell stage (Wishart, 1977; Ahmad et al., 1995).

A high percentage of ewes showed estrus after long-term (12- to 14-day) progestogen treatment, but fertility was lower than after a natural estrus (Robinson et al., 1970). Sub-luteal progesterone concentrations increased the size of the largest follicles and the age of the oldest ovulatory follicles (Dutt and Casida, 1948; Johnson et al., 1996, Viñoles et al., 1999, Flynn et al., 2000). Treatment of non-prolific Western white-faced ewes with $\mathrm{PGF}_{2 \alpha}$ on approximately day 8 of the estrous cycle and a 6-day intravaginal medroxyprogesterone acetate (MAP)-impregnated sponge changed follicular dynamics and increased ovulation rate by approximately $50 \%$ (Bartlewski et al., 2003). Treatment caused $70 \%$ of ewes to ovulate one or more follicles from the penultimate wave as opposed to only $21 \%$ in the control group. Mean ovulation rate was 3.1 in treated ewes as opposed to 2.0 in control ewes (Bartlewski et al., 2003).

In the absence of luteal progesterone, Flynn et al. (2000) found that ewe lambs synchronized with a single progestogen-containing sponge for 14 days had a higher LH pulse frequency and ovulated older follicles of larger diameter than ewe lambs in which sponges were replaced every five days over a 14-day period or controls. The authors reported a 12.1-day lifespan for follicles in ewe lambs treated with the long-duration sponges as opposed to a 5.1-day lifespan for those with the short-duration sponges and a 6.3-day lifespan for control lambs with normal CL. 
Johnson et al. (1996) utilized treatments with subcutaneous implantation of progesterone contained in packets of Silastic sheeting or the injection of progesterone in corn oil subcutaneously into prostaglandin-treated ewes during the estrous cycle. Follicles were older at ovulation and conception rates were lower in ewes with low progesterone concentrations from days 7 to 15 of the estrous cycle ( $<1 \mathrm{ng} / \mathrm{ml} ; 7.9$ days) than in control ewes (progesterone $>1 \mathrm{ng} / \mathrm{ml}$; no prostaglandin treatment; 5.8 days). However, the reduction in fertility was manifested on a ewe basis. Thus, detrimental effects were not localized to the oocyte and the resulting embryo from the older ovulatory follicle, but instead influenced either the fertilization rate or the survival of all embryos.

Viñoles et al. (2001) studied the effect of duration of treatment with MAP (60 mg in an intravaginal sponge) on follicular dynamics, estrous synchronization, and pregnancy rate in Polwarth ewes. Duration of progestogen treatment affected follicular dynamics and determined the age of the follicles that ovulated, and pregnancy rate was related inversely to age of the ovulatory follicles. The ovulatory follicle averaged approximately two days older in the longterm treated group (12 days) versus the short-term treated group ( 6 days). Thus, the authors concluded that the lower pregnancy rate observed after long-term progestogen treatment was related to a slower follicular turnover that promoted the ovulation of persistent follicles.

Conversely, Hogue et al. (1962) found no negative effects on conception after natural mating of ewes fed $60 \mathrm{mg}$ of MAP once daily for 20 days. In fact, conception rate of treated ewes $(61 \%)$ was greater than in ewes bred at normal estrus $(50 \%)$, and treated ewes had a greater lambing rate from first breeding 
than controls. In a similar study, Evans et al. (1962) treated ewes for 14 days with oral MAP and found that $63 \%$ of ewes lambed after breeding at the first post-treatment estrus, which demonstrated that progestogen-treated ewes can have relatively good fertility. Using similar techniques as Viñoles et al. (2001), Evans et al. (2001) found that ewes treated with a single progestogen sponge from days 6 to 20 post-luteolysis ovulated aged follicles (avg. age of 8.7 days) compared to ewes that had sponges replaced on days 11 and 16 and removed on day 20 (average age of 4.5 days). However, fertilization rate, embryo quality, or number of full-term lambs did not differ between groups.

\section{Estrogen}

Spontaneously prolonged cycles are common in aged animals such as the rat and human (reviewed in Butcher, 1972), and are associated with greater embryonic abnormalities and loss. As previously mentioned, in an attempt to mimic the longer estrous cycle of the aged rat, Butcher and Pope (1979) treated rats with normal 4-day estrous cycles with pentobarbital to delay ovulation for 48 hours. A subgroup of these rats was treated with antisera to estradiol on days 1 and 2 of the subsequent estrous cycle, and another group was treated with estradiol antisera and diethylstilbestrol (a synthetic estrogen).

A 48-hour delay in ovulation resulted in decreased implantation, retarded growth, and increased embryonic death. All of the detrimental effects of delayed ovulation were reversed by antisera to estrogen, while diethylstilbestrol reinitiated these effects in estrogen antisera-treated rats. Thus, increased embryonic abnormalities and failures of implantation in the aged rat have been clearly 
shown to be due to extended exposure to high concentrations of estradiol, which altered the follicular and uterine environments of the oocytes (Butcher, 1972; Butcher and Pope, 1979). However, Butcher (1972) suggested that preimplantation stages of rat embryos may show some deviations from normal and still result in apparently normal offspring, because the number of blastocysts classified as normal was sometimes fewer than the number of normal term fetuses (Fugo and Butcher, 1966).

Page and Butcher (1982) showed that increased estrous cycle length in aged rats was associated with an early increase in intrafollicular and plasma concentrations of estrogen in relation to the time of ovulation. This increase in estrous cycle length also resulted in decreased implantation rate and percentage of normal embryos observed on day 11 of pregnancy (Page et al., 1983).

In cattle, when progesterone concentrations are low, a high frequency of LH pulses stimulates continued growth of the ovulatory-sized follicle (Taft et al., 1996) which secretes more estradiol-17 $\beta$. High estrogen to progesterone ratios on days 3 to 6 were associated with abnormally-developed embryos (Maurer and Echternkamp, 1982). Decreases in conception rates in cattle were associated linearly with increased concentrations of estrogen around days 14 to17 after ovulation (Pritchard et al., 1994). Thatcher et al. (1989) found that elevated estrogen concentrations in ovarian follicles during this same time period might be detrimental to pregnancy. Similarly, Johnson et al. (1996) found that ewes treated with low progesterone produced increased amounts of estradiol. Increased estradiol, presumably from the older ovulatory follicle, could have been the factor detrimental to fertility; a greater proportion of ewes with high 
concentrations of estradiol before mating failed to conceive than ewes with low concentrations of estradiol.

\section{Inhibin}

Lopez et al. (2005) showed that cows with three dominant follicles had lower concentrations of immunoreactive (ir)-inhibin than cows with either one or two dominant follicles for 48 hours before deviation. Cows with two dominant follicles had lower ir-inhibin concentrations than those with a single dominant follicle at 30,24 , and 12 hours before deviation. However, the assay used by Lopez et al. (2005) measured only the a subunit of inhibin. Reduction of circulating inhibin by treatment with an inhibin antiserum increased plasma concentrations of FSH and ovulation rate in heifers (Glencross et al., 1994), cows (Akagi et al., 1997), sheep (Kusina et al., 1995), goats (Medan et al., 2003 a; b), and mares (Nambo et al., 1998).

Administration of inhibin, either in the form of steroid-free bovine follicular fluid or in a purified form, to intact or ovariectomized heifers suppressed circulating FSH and, in intact heifers, inhibited follicular growth beyond $5 \mathrm{~mm}$ in diameter (Beard et al., 1990; Kastelic et al., 1990; Wood et al., 1993). A similar situation was found in pituitary stalk-transected and control ewes given bovine charcoal-extracted follicular fluid (bFF) and ovine FSH (Larson et al., 1991). The number of follicles $\geq 2 \mathrm{~mm}$ was reduced by stalk transection and bFF. Although FSH restored follicular development in stalk-transected ewes, it did not overcome inhibition by bFF. Intra-ovarian effects of inhibin are controversial (Ying et al., 1986; Campbell and Baird, 2001). It has been suggested that perhaps inhibin 
metabolism is elevated in high-producing animals as has been previously shown for the metabolism of estradiol and progesterone. Such elevated metabolism would lead to the lower concentrations seen in cows with multiple dominant follicles (Lopez et al., 2005).

A similar situation may occur in sheep with multiple ovulations. Inhibin concentrations were lower in the cytosolic fraction of homogenates of whole ovaries from Booroola ewes than from Merino ewes, indicating a lower content of inhibin in the ovary of the more prolific Booroola ewes (Cummins et al., 1983). Further, Merino ewes immunized against a purified preparation of bovine follicular inhibin had increased ovulation rates (O'Shea et al., 1982). However, Souza et al. (1997) found no difference in the secretion of inhibin A throughout the follicular or luteal phases in ewes with or without the Booroola gene.

\section{Intra-Ovarian Growth Factors}

As reviewed by McNatty et al. $(2003,2007)$, point mutations have been identified in genes from the transforming growth factor $\beta$ (TGF $\beta$ ) superfamily or their receptors in many breeds known for increased ovulation rates (i.e.

Inverdale, Booroola, Garole, etc.). In Inverdale ewes, separate point mutations were identified in the bone morphogenic protein 15 (BMP15) gene corresponding to sites in the mature peptide coding region of the BMP15 growth factor (also known as GDF9; Galloway et al., 2000). This mutation probably results in a marked reduction in BMP15 bioactivity in these ewes. Ewes that are homozygous for this mutation are sterile; however, heterozygous ewes have greater than normal ovulation rates and litter sizes (Davis et al., 2001). 
In Booroola and Garole ewes, a point mutation was identified in the highly conserved intracellular serine threonine kinase signaling domain of the BMP-IB receptor (BMPR-IB; Davis et al., 2002). This represents a non-conservative change in a type 1 BMP receptor. Females that had one copy of the mutation had an ovulation rate of one or two more oocytes than non-carriers, and those with two copies ovulated three to ten more oocytes than non-carriers (McNatty et al., 2001; Davis et al., 2002).

Exactly how the identified mutations elicit increased ovulation rate is not understood. The current hypothesis is that both follicular growth and ovulation rate are influenced by concentration of BMP15 or GDF9 delivered to the somatic cells of the follicle in animals with a low ovulation rate phenotype. Once follicular growth has been initiated, both BMP15 and GDF9 are critical for ongoing development to ovulation (McNatty et al., 2003, 2007). This critical role most likely includes regulation of proliferative and differential functions of adjacent follicular cells. Animals with a high ovulation rate phenotype are relatively insensitive to changes in the concentration of BMP15, but have an absolute requirement for GDF9. Thus, ovulation rate and follicular dynamics may be influenced by oocyte-derived growth factors that are released differentially or recognized based on genetic pre-disposition to these factors.

Rates of development of oocytes from a given follicular class are superior in ewes heterozygous for the Booroola gene when compared to females of wildtype genotype (Cognié et al., 1998). Even in preantral follicles, oocytes from ewes bearing the Booroola gene are larger than oocytes from wild-type animals at the same follicular stage, indicating that oocyte developmental competence is 
acquired much earlier with this genetic mutation (reviewed in Mermillod et al., 1999).

In cattle, blastocyst development was correlated to follicular fluid concentrations of estradiol (Van de Leemput et al., 1998). Also, follicles with increased aromatase activity were more likely to contain oocytes capable of developing to the blastocyst stage (Driancourt et al., 1998).

\section{Manipulation of Follicular Growth}

Enhanced precision of timing of estrus depends on controlling the corpus luteum and follicular development (Fogwell et al., 1986). In order to synchronize estrus in cattle, development of the dominant follicle must be controlled. For example, synchrony of the LH surge depends on the homogeneity of the population of large follicles among animals at the time of treatment with $\mathrm{PGF}_{2 \alpha}$ (Sirois and Fortune, 1990). Different methods have been used to induce emergence of a new follicular wave. Selected hormonal and physical treatments will be discussed in some detail.

\section{GnRH}

$\mathrm{GnRH}$ analogs have been used to synchronize follicular wave emergence and ovulation in cattle (Martinez et al., 1999; Roche et al., 1997; Sirois and Fortune, 1988; Twagiramungu et al., 1992; Schmitt et al., 1996; and Wiltbank, 1997). Treatment with $\mathrm{GnRH}$ caused emergence of a new wave within an average of two days (Martinez et al., 1999; Roche et al., 1997; Sirois and Fortune, 1988; Twagiramungu et al., 1992; and Wiltbank, 1997). 
In a study by Roche et al. (1997), 18 of 20 randomly cycling, lactating dairy cows and 13 of 24 dairy heifers ovulated after $\mathrm{GnRH}$ treatment, and it was presumed that a new follicular wave emerged at that time. In another study, a new follicular wave emerged, on average, two days after $\mathrm{GnRH}$ treatment in 53 of 53 cows and in 18 of 24 heifers (Wiltbank, 1997). In an experiment in which $\mathrm{GnRH}$ or LH was administered at various phases of the first follicular wave, ovulation of the dominant follicle was induced in 56 or $78 \%$ of heifers, respectively (Martinez et al., 1999). Heifers that failed to ovulate following the second $\mathrm{GnRH}$ treatment in an Ovsynch protocol were reported to be in metestrus or early diestrus at the first GnRH treatment (Pursley et al., 1995).

Controlling the time of emergence of the dominant follicle has been facilitated by administration of $\mathrm{GnRH}$ or an estrogen in conjunction with a progestin. Emergence of a new follicular wave occurred about 1.5 days after $\mathrm{GnRH}$ administration (Bentley et al., 1998). A single injection of $\mathrm{GnRH}$ analog in the mid-luteal phase did not change total number of follicles, but the percentage of cloudy (authors assumed probably atretic or luteinized) follicles increased acutely, and a greater proportion of cows treated with $\mathrm{GnRH}$ analog subsequently ovulated a newly recruited follicle (Macmillan and Thatcher, 1991).

In mid-luteal phase cows, GnRH analogs disrupted normal follicular dynamics by decreasing the number of large ovulatory-sized follicles through luteinization and/or atresia (Macmillan et al., 1985; Thatcher et al., 1989). In cows, in response to $\mathrm{GnRH}$ treatment, the large follicle either ovulated or continued its regression by atresia depending on its stage of development (Twagiramungu et al., 1995). Treatment with a GnRH agonist synchronized 
emergence of a new follicular wave and selection of a large follicle within three to four days after PGF-induced luteolysis. Twagiramungu et al. (1994) reported that a new wave emerged regardless of the luteal status at the time of $\mathrm{GnRH}$ treatment and regardless of whether ovulation was induced by $\mathrm{GnRH}$.

Martinez et al. (2000) treated beef heifers $(N=16)$ at random stages of the estrous cycle with $100 \mu \mathrm{g} \mathrm{GRH}$ i.m., inserted a (CIDR-B) intravaginally for six days, and then treated with PGF (5 mg i.m. of Prostavet $($ ) at CIDR removal and 12 hours later. Eight of 16 heifers ovulated following treatment, but this did not alter the timing of the mean wave emergence, which was 1.5 days after CIDR removal (Martinez et al., 2000). Variability of the interval to wave emergence was less in those heifers that responded to $\mathrm{GnRH}$ by ovulation at the time of injection than in those that did not ovulate (Martinez et al., 2000). Administration of GnRH during the late growing or early static phase of dominant follicle development caused ovulation with synchronous emergence of a new wave in a high percentage of heifers (Martinez et al., 1999). However, when GnRH was given at other stages of dominant follicle development, ovulation was much less likely to occur and wave emergence occurred spontaneously (either synchronously by chance or asynchronously; Martinez et al., 2000).

When $\mathrm{GnRH}$ treatment was compared to similar treatment with estradiol $17 \beta$ and progesterone $(E / P)$ or with follicular ablation $(F A)$ via transvaginal ultrasound-guided aspiration of all follicles $\geq 5 \mathrm{~mm}$ in diameter, Martinez et al. (2000) found that synchrony of wave emergence was significantly less variable in groups treated with E/P or FA than in the $\mathrm{GnRH}$-treated group. However, the 
interval from PGF treatment to estrus was very synchronous in all groups (Martinez et al., 2000).

\section{Surgical Ablation}

In cattle, when the dominant follicle was eliminated by cautery, plasma concentrations of $\mathrm{FSH}$ rose and a new follicular wave emerged in approximately two days (Bergfelt et al., 1994). The same effect was seen with ultrasoundguided follicular ablation (Bo et al., 1995a). Follicular ablation via transvaginal ultrasound-guided aspiration of all follicles $\geq 5 \mathrm{~mm}$ in diameter followed by insertion of a CIDR-B for five days caused wave emergence to occur approximately one day (range 0 to 2 days) after follicle aspiration (Martinez et al., 2000). However, estrus and ovulation appeared to occur later in this group of heifers than in groups treated with $\mathrm{E} / \mathrm{P}$ or $\mathrm{GnRH}$, which may have been due to the smaller size of the dominant follicle at the time of progesterone withdrawal (Martinez et al., 2000).

Removal of the largest follicle in ewes on day 4.5 of the estrous cycle by cautery gave similar results to experiments in cattle, in which the removal of the dominant or largest follicle delayed regression of the second largest follicle (Evans et al., 2002). However, contrary to findings with cattle, new wave emergence occurred at a similar time in treated ewes and control ewes (day 7.2 vs. 6.8, respectively). Evans et al. (2002) speculated that, because circulating concentrations of estradiol were decreasing and FSH concentrations were increasing at the time of surgery, a new wave was already in the process of emergence in all groups. Follicular ablation increased FSH concentrations and 
stimulated growth of more small follicles than in control ewes (Evans et al., 2002).

\section{Estradiol and Progesterone}

Estrogens effectively synchronized follicular wave emergence in cattle (Bo et al., 1995b, 1996; Caccia and Bo, 1998; Bridges et al., 1999). The administration of estradiol valerate $(E V)$ caused regression of antral follicles (CRRP, 1996). However, the long half-life of EV led to poor synchrony of wave emergence (Bo et al., 1995b). Estradiol-17 $\beta$ induced follicular regression as well as synchronizing emergence of a new follicular wave (Bo et al., 1993). Intramuscular administration of estradiol benzoate (EB) more effectively synchronized follicular wave emergence than intravaginal administration of an estradiol benzoate capsule (Bo et al., 1996).

Because estradiol treatment alone in animals with low endogenous plasma concentrations of progesterone caused a surge in plasma $\mathrm{LH}$ and decreased synchrony of follicular wave emergence (Bo et al., 1994), progesterone has been included in synchronization schemes to suppress estradiol-induced release of LH (Bo et al., 1996). Addition of progesterone may improve the efficacy of estradiol in inducing regression of larger antral follicles (Anderson and Day, 1994, 1998; McDowell et al., 1998; Bridges et al., 1999). In progestogen-treated heifers given $5 \mathrm{mg}$ estradiol-17 $\beta$, a new follicular wave emerged in an average of 4.3 days, regardless of the stage of development of the dominant follicle at the time of treatment (Bo et al., 1993, 1994). As previously mentioned, Martinez et al. (2000) found that heifers treated with $5 \mathrm{mg}$ 
of estradiol-17 $\beta$ and $100 \mathrm{mg}$ of progesterone, a CIDR-B for eight days, and PGF at CIDR removal and 12 hours later, had shorter and more consistent intervals from PGF treatment to both estrus and ovulation than heifers treated with $\mathrm{GnRH}$ (range 1.5 days). A new follicular wave emerged between three and four days after treatment (Martinez et al., 2000).

Engelhardt et al. (1989) administered $10 \mathrm{mg} \mathrm{EV}$ to nonlactating Holstein cows on day 16 of the estrous cycle and caused ovulation in 7 of 8 cows. The timing of luteolysis and the LH surge post-treatment was variable, but in the normal range for the 7 animals (range 16 to 136 hours post-treatment). At slaughter 14 days post-treatment, each of these cows had an ovulatory-sized follicle on their ovaries and basal progesterone concentrations, indicating that they had not ovulated again post-treatment. A second group of animals was treated with EV as before or not injected and was ovariectomized on day 17, $18.5,20$, or 21.5 . Histologically, the largest follicle in the treated animals was atretic both before and after luteolysis, while controls had a largest follicle that was atretic before but not after luteolysis. These authors suggested that EV prevented ovulation by inducing atresia of the potential preovulatory follicle which was then replaced within 14 days post-treatment. In a similar experiment (Rajamahendran and Walton,1990), atresia of the preovulatory follicle occurred prior to the $\mathrm{E} 2$-induced $\mathrm{LH}$ release. This means that $\mathrm{EV}$ was able to induce atresia of the dominant follicle before 40 to 65 hours post-treatment.

Bo et al. (1991) treated cows at unknown times in their cycle with SyncroMate $\mathrm{B}(\mathrm{SMB}$ ) implants (day 0 ) and then gave $5 \mathrm{mg} \mathrm{EV}$ either on day $0,2,7$, or 9 (day 9 was time of superstimulation with $\mathrm{FSH}$ ). There was a dramatic reduction in 
diameters of the largest and second largest follicles following EV treatment in all cows. However, even when this dose of EV was given as early as day 2 after implant, there were still no follicles greater than $8 \mathrm{~mm}$ in diameter present in this group at the time of superstimulation on day 9. A typical population of dominant large follicles existed in cows not treated with EV at these same times.

Colazo et al. (2005) gave Holstein cows at random stages of the estrous cycle two SMB implants (day 0) and randomly assigned animals to receive $5 \mathrm{mg}$ EV and $3 \mathrm{mg}$ norgestomet on day 0 or $5 \mathrm{mg}$ estradiol- $17 \beta$ and $100 \mathrm{mg}$ progesterone on day 1 . Treatment with $5 \mathrm{mg} \mathrm{EV}$ resulted in a longer and more variable interval to follicular wave emergence than treatment with $5 \mathrm{mg}$ estradiol$17 \beta$. Additionally, $5 \mathrm{mg}$ EV appeared to induce luteolysis in heifers, reducing the interval to ovulation following norgestomet removal. In the same study, Colazo et al. (2005) compared the effect of dosage of EV on ovarian follicular and luteal growth profiles and synchrony of estrus and ovulation. Cows at random stages of the estrous cycle received a CIDR and no further treatment, or an injection of 1 , 2, or $5 \mathrm{mg}$ i.m. of EV. On day 7, CIDRs were removed and cows received PGF. Follicular wave emergence occurred within seven days in 7 of 10 control cows and 31 of 32 EV-treated cows. In cows that responded, interval from treatment to follicular wave emergence was longer in those treated with $5 \mathrm{mg} \mathrm{EV} \mathrm{(4.8} \mathrm{days)}$ than in those treated with 1 (3.2 days) or 2 (3.4 days) mg EV, while intervals were intermediate in control cows (3.8 days). Thus, reduced dosages of EV may be more useful for the synchronization of follicular wave emergence in progestogen-treated animals. 
It may be inferred from the data that superstimulation treatments utilizing the SMB implant will yield results similar to those using the $C L$ of the cycle (Bo et al., 1991). Similar effects of estrogen and progesterone treatment should be seen in other ruminant species such as sheep. Although combinations of estrogen and progesterone normally have not been used to cause atresia of large follicles in sheep, studies have been done to determine the luteolytic effects of estrogen treatment at different times of the cycle.

Hawk and Bolt (1970) observed significantly reduced luteal weights by day 14 with estradiol treatments of either 250 or $750 \mu \mathrm{g}$ on day 9 and 10. Additionally, they treated five ewes with $100 \mu \mathrm{g}$ of estradiol per day and found that two of those ewes had CL that regressed in size due to treatment. Similarly, Ford et al. (1975) treated cyclic ewes on days 4 and 5 or 9 and 10 with $0.5 \mathrm{mg}$ estradiol-17ß and excised and weighed CL 18 hours following the last injection. Neither treatment had an effect on CL weight or progesterone secretion. However, ewes treated on day 11 had greater concentrations of PGF, and it was assumed that if $\mathrm{CL}$ had been removed a little later, premature regression of the $C L$ would have been detected.

\section{Conclusion}

From these studies, it appears that in some situations there may be a difference in oocyte competence and subsequent fertility resulting from different follicular ages or steroid exposures. These differences may help to explain the high rate of embryonic and fetal mortality found in sheep, although the specific connection has yet to be elucidated. Treatments with $\mathrm{GnRH}, \mathrm{LH}$, and ovarian 
steroids, as well as physical ablation show promise as means to alter follicular growth and reduce age of the ovulatory follicle(s) in the ewe. It appears that such approaches can be used to prevent ovulation of follicles in the penultimate wave. 


\section{STATEMENT OF THE PROBLEM}

A main goal of sheep producers is to increase the number of lambs produced per ewe by increasing pregnancy rates and prolificacy. Although average ovulation rates of most breeds are sufficient, a significant economic loss results from the fact that a large percentage of those ovulations do not result in live offspring. Fertilization rate in ruminants is generally high (90 to $95 \%$ ); however, only approximately 60 to $80 \%$ (or less) of ovulations result in live births. This means that 10 to $30 \%$ of losses of potential offspring result from embryonic or fetal deaths. More than $30 \%$ of ewes that retain pregnancy lose part of the number of embryos or fetuses that they carry before birth. As ovulation rate increases, so does the number of ovulations not represented by live births. Therefore, not only open ewes, but ewes with low prolificacy can be a source of economic loss.

In cattle and rats, greater embryonic losses are associated with the ovulation of aged follicles (those that have been on the ovary for a longer than optimal time). Sheep may increase ovulation rate by ovulating more follicles that have been on the ovary for longer periods of time. This extension in follicular recruitment might result in multiple follicles of different ages ovulating at the same time. Based on the literature reviewed, as ovulation rate increases in ewes, decreases in oocyte competence and subsequent fertility may result. These differences might help to explain the high rates of embryonic and fetal mortality found in sheep. 
Therefore, to determine if there is a positive relationship between follicular age and competence of oocytes and how this might be related to wave source or steroid concentration, three methods of follicular manipulation were utilized to prevent ovulation of follicles from the penultimate wave in ewes. The hypothesis was that changes in the age of the ovulatory follicle(s) produced by ablation or hormone-induced atresia of potentially ovulatory follicles of the penultimate wave would affect fertility or embryonic and fetal mortality in ewes. Specific aims for this study were:

1) to compare conception rates, embryonic mortality, and prolificacy in ewes ovulating follicles from only the ultimate wave (younger) or those ovulating follicles from both the penultimate and ultimate waves (older and younger),

2) to measure patterns of progesterone and estradiol in peripheral blood to categorize ewes into low or high progesterone groups (and low or high estradiol groups), and to determine if follicular age or competence of the ovulatory follicle(s) are related to concentrations of these hormones,

3) to determine if follicular wave source (penultimate vs. ultimate), as determined by retrospective mapping of follicular growth, or follicular age has an effect on oocyte competence as reflected by embryonic and fetal mortality. 


\section{MATERIALS AND METHODS}

Three approaches to ablate or cause regression of potentially ovulatory follicles from the penultimate follicular wave were tested in ewes. The aim was to create a model in which ewes with ovulatory follicles developed only from the ultimate follicular wave could be compared to control animals ovulating from both ultimate and penultimate waves.

\section{Experiment 1: GnRH Injection}

\section{Rationale}

As little as $1.25 \mu \mathrm{g}$ i.v. of $\mathrm{GnRH}$ increased LH secretion in sheep (Wheaton et al., 1982). A $100 \mu \mathrm{g}$ dose of $\mathrm{GnRH}$ (i.m. or i.v.) is used in the Ovsynch protocol in cattle to cause either luteinization or atresia of the dominant follicle. A dosage of $50 \mu \mathrm{g}$ was just as effective (Fricke et al., 1998). Because the ewe is a much smaller animal than a cow, it was speculated that $50 \mu \mathrm{g}$ of $\mathrm{GnRH}$ should cause luteinization or atresia of follicles. The objectives of this study were to ascertain whether $\mathrm{GnRH}$ caused ovulation or atresia of potentially ovulatory follicles of the penultimate follicular wave in ewes, and to determine if treatment with $\mathrm{GnRH}$ changed estrous cycle length, follicular wave dynamics, ovulation rate, fertility, and number of embryos during early pregnancy in ewes.

\section{Animals and Treatment}

In Fall of 2003, mature crossbred Suffolk and Dorset ewes from the West Virginia University research flock $(N=26)$ observed to have had at least one normal estrous cycle (14 to18 days in length) prior to the experiment were 
studied. Ewes were given two injections of 5 mg PGF $2 \alpha$ (Lutalyse, Pfizer Animal Health, New York, NY) 3 hours apart to synchronize estrus. Ewes were scanned by transrectal ultrasonography using the method of Schrick and Inskeep (1993) daily from day 7 of the synchronized estrous cycle (day $0=$ observed estrus using raddled vasectomized rams) until ovulation at post-treatment estrus. Ovarian maps were used to record all significant structures, identified by ultrasonography, on the ovaries of each ewe (follicles $\geq 2 \mathrm{~mm}$ and $\mathrm{CL}$ ). Ewes were assigned randomly to control $(n=13)$ or $\mathrm{GnRH}$-treated $(n=13)$ groups. Treated ewes were injected with $50 \mu \mathrm{g}$ of $\mathrm{GnRH}$ (2 ml Cystorelin, Merial Ltd.; i.m.) on day 11 in an attempt to cause ovulation, luteinization, or regression of ovulatory-sized follicle(s). Control ewes were given no treatment.

One treated ewe was removed from the study after having an abnormally long estrous cycle (> 25 days). Ewes were exposed to two rams of known fertility from day 12 of the synchronized cycle for nine days. Corpora lutea were counted by ultrasonography approximately seven days following post-treatment estrus in order to verify ovulation. Pregnancy was determined 23 to 28 days following ovulation and embryos (if present) were counted. Pregnant ewes were given two injections of 5 mg PGF $2 \alpha$ (Lutalyse, Pfizer Animal Health, New York, NY) 3 hours apart on approximately day 30 to 35 of gestation to terminate pregnancies.

\section{Experiment 2: Follicular Ablation}

\section{Rationale}

Due to the fact that treatment with GnRH did not alter follicular growth, the proven method of follicular ablation at surgery was utilized to remove largest 
follicles of the penultimate wave $(\geq 4 \mathrm{~mm}$ ) from the ovary. Although not practical from a management standpoint, this method would insure removal of the targeted large follicles.

\section{Morgantown Study (Replicate 1)}

A preliminary study was conducted in fall of 2004 with crossbred Suffolk and Dorset ewes from the West Virginia University research flock $(N=29)$. These ewes were known to have had at least one normal estrous cycle (14 to 18 days in length) prior to the experiment and were observed daily for natural estrus using raddled vasectomized rams. Daily ultrasonography began on day 9 of the estrous cycle using the same protocol as in Exp. 1. For surgery, ewes were initially anesthetized by $0.3 \mathrm{mg} / \mathrm{kg}$ diazepam and $7 \mathrm{mg} / \mathrm{kg}$ ketamine, and then placed on a mixture of halothane and nitrous oxide gases until midventral laparotomy was completed. The largest and second largest follicle(s) $(\geq 4 \mathrm{~mm}$, two of second largest in case of a tie) on each ovary were electrocauterized on day 11 in treated ewes $(n=15)$. In control ewes $(n=14)$, sham surgery included cautery of a portion of ovarian stroma not containing follicles.

Ewes were exposed to two rams of known fertility beginning on day 12 after pre-treatment estrus and observed for estrus for up to nine days. Corpora lutea were counted by transrectal ultrasonography approximately seven days following post-treatment estrus. Pregnancy was determined and embryos (if present) were counted 23 to 28 days following estrus. Pregnant ewes were given two injections of 5 mg PGF $_{2 \alpha}$ (Lutalyse, Pfizer Animal Health, New York, NY) 3 hours apart on approximately day 30 to 35 of gestation to terminate pregnancies. 


\section{Idaho Study (Replicate 2)}

In fall of 2005 , four groups of mature multiparous Polypay ewes $(n=$ approximately 50 per group; $N=198$ ) located at the U.S. Sheep Experiment Station in Dubois, Idaho were given 20 mg PGF $2 \alpha$ (Lutalyse, Pfizer Animal Health, New York, NY) once on four consecutive days (once per group). Eleven days following expected synchronized estrus in the first group, a subset of ewes $(n=30)$ was chosen randomly to undergo daily ultrasonography as described for replicate 1. Four ewes from the group followed by ultrasonography were dropped from study due to abnormal uterine physiology or estrous cycle length.

Ewes determined to be healthy $(N=191)$ were anesthetized with pentobarbital (65 mg/mL i.v., 6 to $12 \mathrm{~mL}$, to effect) and underwent midventral laparotomy 13 days following synchronization (estimated to be day 11 of the estrous cycle). Ewes were assigned to treatment randomly within age. Treated ewes $(n=96)$ and control ewes $(n=92)$ were treated as described in replicate 1 except that all large follicles ( $\geq 4 \mathrm{~mm}$ ) on each ovary were cauterized in treated ewes (not just the largest two).

Raddled intact rams (approximately one ram for every ten ewes) were introduced approximately one day after surgery into all groups. Marks by rams (indicating estrus) were recorded for all ewes daily for ten days after ram introduction. Number of ovulations was determined for each ewe by counting $\mathrm{CL}$ by transrectal ultrasonography approximately seven days after mean day of estrus for all groups. Pregnancy diagnosis was performed approximately 25 days after mean day of estrus in all groups. Pregnancy was diagnosed again at approximately 60 days after mean estrus in all groups and fetuses were counted. 
Lambing data were collected from all ewes. Thirteen ewes died from unknown causes from the time of surgery until lambing and were removed from analyses.

\section{Experiment 3: Steroid Injection}

\section{Rationale}

Follicular ablation by surgery is not practical from a management standpoint. Having created a situation in which all follicles originated from the ultimate wave using follicular ablation in replicate 1 of Experiment 2, it was desired to find a less-invasive means of treatment in order to create a more practical application method. Based on the literature reviewed, a single treatment of no more than $100 \mu \mathrm{g}$ estradiol benzoate (EB) should be sufficient to cause the regression, luteinization, or ovulation of ovulatory-sized follicles in the ewe. Further, as Martinez et al. (2004) had success using as little as $1 \mathrm{mg}$ estradiol valerate $(\mathrm{EV})$ in combination with only $50 \mathrm{mg}$ progesterone in cattle, a single dose of 25 or $50 \mathrm{mg}$ of progesterone was estimated to be sufficient to reduce $\mathrm{LH}$ support and allow atresia rather than ovulation of largest follicles in ewes.

\section{Preliminary Study}

Suffolk ewes located at the WVU Livestock Farm in Morgantown, West Virginia were utilized in the anestrous season to test dosages of EB and progesterone. All ewes had their ovaries scanned by ultrasonography from two days prior to treatment to at least two days post-treatment. Ewes that had at least one ovulatory-sized follicle ( $\geq 4 \mathrm{~mm}$ ) that grew (and was not regressing) over the first two days were utilized. Ewes were not treated (controls, $n=5$ ), or treated 
with $50 / 25,100 / 25,50 / 50$, or $100 / 50$ ( $\mu$ g EB to $\mathrm{mg}$ progesterone in corn oil, $n=5$, 5,3 , and 6 , respectively). Ovarian maps were analyzed retrospectively to determine if treatment was followed by follicular regression within two days. Only 2 of 5 animals in the control group had regression of ovulatory-sized follicles within two days after treatment day. Ewes in the 50/25 and 100/25 $\mu \mathrm{g}$ EB to mg progesterone groups were not different from control ewes ( 1 of 5 and 3 of 5 ewes had follicles that regressed within two days, respectively). The 50/50 and 100/50 $\mu \mathrm{g}$ EB to mg progesterone groups had apparently better results with follicular regression occurring in 3 of 3 and 5 of 6 ewes, respectively. Thus, it was decided that both the 50/50 $\mu \mathrm{g}$ EB to mg progesterone (steroid-50) and 100/50 $\mu \mathrm{g}$ EB to mg progesterone (steroid-100) dosages would be used in the main study.

\section{Wardensville Study}

In May of 2006, Katahdin, Suffolk, and Dorset crossbred ewes and yearling lambs $(\mathrm{N}=110)$ at WVU's Reymann Memorial Farms in Wardensville, West Virginia were given progesterone (25 mg, i.m.; Sigma Chemical Co., St. Louis, Missouri) at ram introduction ( $\mathrm{n}=10 \mathrm{rams}$ ) to induce ovulation out of season. Fourteen days following ram introduction, 20 mg PGF $2 \alpha$ (Lutalyse, Pfizer Animal Health, New York, NY) was given i.m. to all ewes to synchronize estrus. Raddled vasectomized rams $(n=5)$ were used to determine day of estrus in all ewes. Ninety two ewes that showed estrus were randomized, within face color and \% Katahdin, into one of three groups: control (C), treated with 50/50 $\mu \mathrm{g}$ EB to $\mathrm{mg}$ progesterone (steroid-50), or treated with 100/50 ug EB / mg progesterone 
(steroid-100). Treatments were given on day 10 of the estrous cycle (estrus $=$ day 0$)$. Intact raddled rams $(n=7)$ were introduced at treatment.

A subset of 21 ewes (seven from each group) was scanned by transrectal ultrasonography as previously described in Experiments 1 and 2. Two of these ewes were dropped from the study due to unusually long estrous cycles ( $\geq 21$ days, one control and one steroid-50). Approximately seven days following posttreatment estrus, all ewes were scanned by transrectal ultrasonography to determine the number of ovulations represented by $C L$ on both ovaries. Pregnancy was determined by ultrasonography between days 25 and 30 after first estrus post-treatment. Embryos were counted at pregnancy diagnosis, and fetuses, if present, were counted on days 100 to 110 . Lambing data were collected from all ewes.

\section{Statistical Analyses}

Percentage of ovulations from each wave and categorical age of ovulatory follicles in ewes with ultrasonographic data were compared by the Chi-square procedure of SAS (SAS Institute, Cary, NC), except that Fisher's exact test was used if there were fewer than five ewes per cell. Average age of ovulatory follicles was compared by a Student's T-test. Effects of treatment on proportions of ewes pregnant, lambing, number of $\mathrm{CL}$ not represented by embryos, fetuses, or lambs born, and embryos not represented by fetuses were tested by Chisquare or Fisher's exact test. Number of lambs born was compared by ANOVA. 


\section{Analyses of Ovulation Data Across Experiments}

Due to the fact that treatments with $\mathrm{GnRH}$, electrocautery, and steroids did not alter the average age of the ovulatory follicle, follicular data from ewes scanned daily by transrectal ultrasonography were reorganized to determine effects of age of follicle on embryonic or fetal loss. Ninety four ewes with ovulations $(\mathrm{N}=180)$ for which the follicle was present on the ovary (from $\leq 2 \mathrm{~mm}$ in diameter) for a known number of days and pregnancy data were studied. Data were analyzed retrospectively from follicle maps created by daily ultrasonographic scanning and ovulation, embryo, and lambing records when available. Only ovulations from the Idaho and Wardensville experiments had lambing data included in loss. Ewes were categorized by the age of ovulatory follicle(s) they ovulated (young, $25 \%$ of ovulations; medium, $50 \%$ of ovulations; or old, $25 \%$ of ovulations, within location) or by the follicular wave(s) from which they ovulated (ultimate and/or penultimate or earlier). Overall loss of embryos (and fetuses, when available) per ewe was calculated and related to age of follicle or follicular wave of origin. 


\section{RESULTS}

\section{Experiment 1: GnRH Treatment}

Treatment with GnRH was followed by early return to estrus and ovulation in 3 of

12 treated ewes and one treated ewe did not ovulate; these ewes were not included in the analysis. Excluding these four ewes, length of the estrous cycle did not differ between control and treated ewes (mean $17 \pm 0.3$ days). Ovulation rate did not differ between groups and averaged $2.1 \pm 0.1$ ovulations per ewe. However, treatment with $\mathrm{GnRH}$ did not produce atresia of more of the 3 largest penultimate follicles $\geq 4 \mathrm{~mm}$ ( 25 of 37 ) than was seen in controls (19 of 29 ; Fig. 2). Likewise, treatment with $\mathrm{GnRH}$ did not alter the follicular wave from which the ovulatory follicle(s) originated (ultimate versus penultimate or earlier; Fig. 3), or the age of the ovulatory follicle ( $5.6 \pm 0.6$ versus $6.2 \pm 0.5$ days, in control and treated, respectively). Pregnancy rates did not differ with treatment; only one treated ewe was diagnosed not pregnant. Five ewes, two (of 13) control and three (of 9) treated, had fewer embryos than CL at ultrasonography on day 23 to 28. 


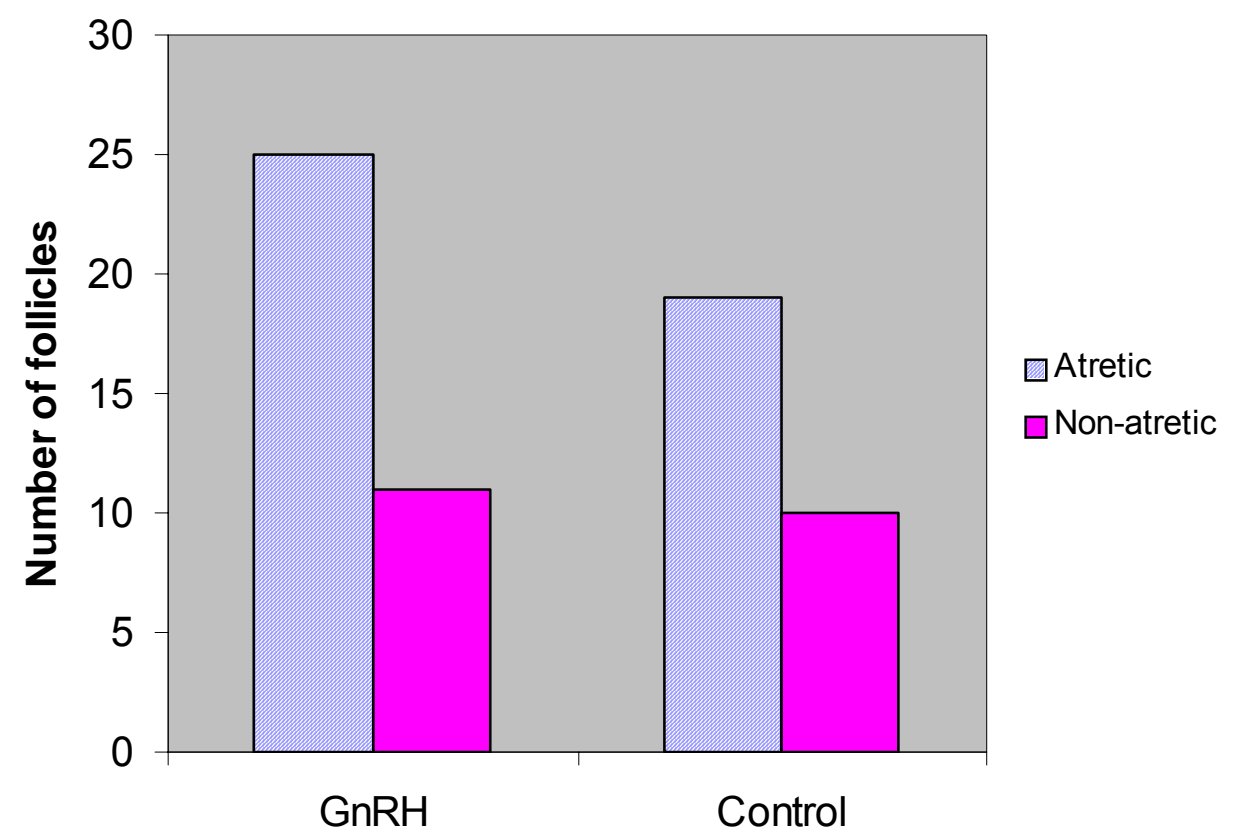

Figure 2: Effect of $\mathrm{GnRH}$ on follicular atresia. Treatment with $50 \mu \mathrm{g}$ of $\mathrm{GnRH}$ did not alter proportion of penultimiate follicles $\geq 4 \mathrm{~mm}$ that became atretic within two days of treatment. 


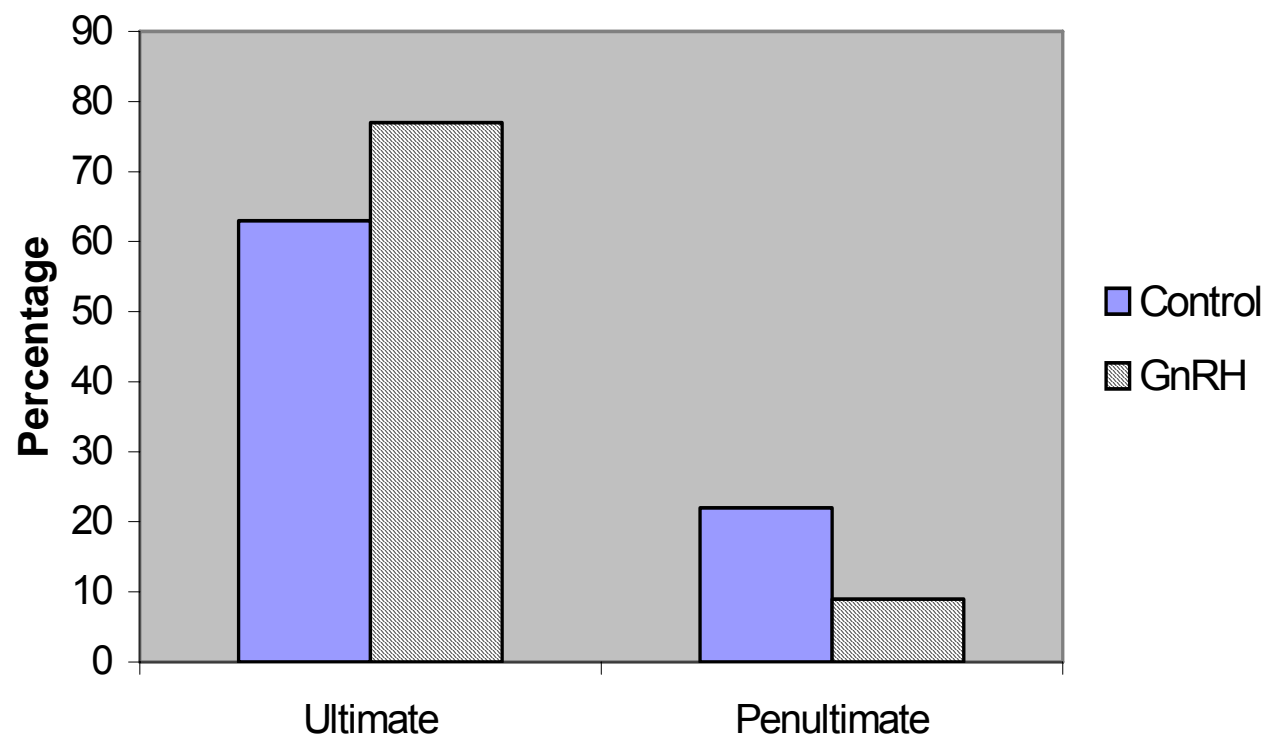

Figure 3: Effect of treatment on percentages of ovulations from different wave sources. Treatment with $50 \mu \mathrm{g}$ of $\mathrm{GnRH}$ did not affect the source of ovulatory follicles.

\section{Experiment 2: Follicular Ablation by Surgery}

\section{Morgantown Study (Rep. 1)}

After follicular ablation, $100 \%$ of ovulations in treated ewes were from the ultimate follicular wave vs. $64 \%$ in control ewes $(P<0.05)$. Average age (days from detection at $2 \mathrm{~mm}$ ) of the ovulatory follicle was $5.1 \pm 0.3$ days in both control and treated ewes. However, the average age of ovulatory follicles of control ewes was a composite of a binomial distribution; follicles from the penultimate wave were $7.4 \pm 0.5$ days old versus $4.3 \pm 0.3$ days for follicles from the ultimate wave. Estrous cycle length did not differ between groups (17.1 \pm 0.4 days). Pregnancy rate was high for both control and treated ewes, with only one ewe from each 
group losing a pregnancy confirmed by ultrasonographic visualization of uterine fluid with no viable embryo(s). Six (of 15) treated and four (of 14) control ewes had CL not represented by embryos on days 23 to 28 .

\section{Idaho Study (Rep. 2)}

Follicular ablation did not alter the average age of the ovulatory follicles tracked by ultrasonography (average age detected on the ovary $\geq 2 \mathrm{~mm} 4.4 \pm 0.2$ days). Likewise, proportions of follicles from different waves did not differ with treatment (overall mean, $91 \%$ ultimate).

Treatment increased the interval from treatment to estrus from $5.4 \pm 0.2$ days in control ewes to $6.2 \pm 0.3$ days in treated ewes $(P<0.05)$. Neither number of $C L$ seven days post-estrus $(2.5 \pm 0.9)$ nor pregnancy rates $(87 \%)$ differed between treated and control ewes. Finally, number of lambs born per ewe lambing $(2.2 \pm 0.1)$ and number of $C L$ not represented by lambs born (mean $0.7 \pm 0.9)$ did not differ with treatment.

\section{Experiment 3: Steroid Treatment}

Treatment with two different dosages of EB and progesterone did not increase regression or luteinization of the largest penultimate follicles $(\geq 4 \mathrm{~mm})$ in treated Katahdin cross ewes (atresia of 17 of 34 follicles) compared to controls (atresia of 8 of 14 follicles). Regression of ovulatory-sized follicles did not differ with dosage of estrogen ( 8 of 16 follicles for steroid-50 versus 9 of 18 follicles for steroid-100). Treatment did not alter the average age of the ovulatory follicle (mean $5.9 \pm 0.3$ days) or the proportion of ovulations from the ultimate versus the 
penultimate or earlier waves ( $79 \%$ ultimate verus $21 \%$ earlier than ultimate).

Treatment with steroid-50 decreased days from treatment to estrus compared to steroid-100 and control ewes $(6.0 \pm 0.3$ versus $6.8 \pm 0.1$ and $6.6 \pm 0.2$ days; $P<$ 0.05). Proportion of ewes with CL seven days post-estrus did not differ with treatment (mean 94\%), nor did number of CL per ewe ovulating (mean $1.6 \pm 0.1$ ). Neither proportions of ewes diagnosed pregnant between days 20 and $30(84 \%)$, nor lambing from first service (75\%), nor number of lambs born per ewe lambing $(1.4 \pm 0.5$ lambs $)$ differed with treatment. Dosage of estrogen did not alter number of $\mathrm{CL}$ not represented by embryos or fetuses, number of embryos not represented by fetuses, or proportion of ewes losing partial or total pregnancies. When results from the steroid-treated groups were combined, treatment tended to increase number of $C L$ not represented by embryos per ewe diagnosed pregnant $(16 \%$ versus $32 \%$, control versus treated; $P=0.08)$. No effects of treatment on follicular wave source, fetal loss, loss from CL count to lambing, or type of loss (total or partial) were found.

\section{Analyses of Ovulation Data Across Experiments}

More ewes with multiple ovulations had CL not represented by embryos or fetuses (loss) than those with single ovulations ( $45 \%$ multiple versus $8 \%$ single; $P<0.05)$. Loss tended to vary by experimental location. Fifty five percent of Polypay ewes in Idaho and 30 and $25 \%$ of the less prolific Suffolk/Dorset and Katahdin cross ewes in Morgantown and Wardensville, respectively, had CL not represented by embryos or fetuses $(P=0.08)$. 
When only data for ewes with ultrasonographic characterization of follicles were considered, there was no association of loss with any particular age category of follicles (young, medium, old; Table 2). Loss tended to differ among follicular age combinations ( $P=0.07$; Table 3 ); however, older follicles did not have worse outcomes than others. Category of follicular wave source(s) (ultimate and/or penultmate) differed by experimental location $(P<0.05$; Table 4$)$, and loss differed by category of wave source(s) $(P<0.05$; Table 5$)$.

Table 1: Follicular age categories based on days mapped on the ovary from $\geq 2$ $\mathrm{mm}$ until ovulation by location.

\begin{tabular}{lccc}
\hline & \multicolumn{3}{c}{ Days on ovary from $\geq 2 \mathrm{~mm}$ to ovulation by location } \\
\cline { 2 - 4 } $\begin{array}{l}\text { Age Category } \\
\text { by location }\end{array}$ & Morgantown, WV & Wardensville, WV & Dubois, Idaho \\
\hline & $2-3$ & $2-4$ & $2-3$ \\
Young (bottom 25\%) & $4-6$ & $5-7$ & $4-5$ \\
Medium (middle 50\%) & $\geq 7$ & $\geq 8$ & $\geq 6$ \\
Old (top 25\%) & & & \\
\hline \hline
\end{tabular}


Table 2: Association of embryonic or fetal loss by ewes with age category of ovulatory follicle(s) $(\mathrm{P}>0.10)$.

\begin{tabular}{llc}
$\begin{array}{l}\text { Category of ovulation(s) } \\
\text { by ewe }\end{array}$ & $\mathrm{n}$ & Loss (\%) \\
\hline Had Young Follicles & 25 & 32 \\
No Young Follicles & 69 & 35 \\
Had Medium-Aged Follicles & 68 & 37 \\
No Medium-Aged Follicles & 26 & 27 \\
Had Old Follicles & 34 & 29 \\
No Old Follicles & 60 & 37 \\
\hline \hline
\end{tabular}

Table 3: Association of embryonic or fetal loss by ewes with specific age categories of combinations of ovulatory follicle(s) $(P=0.07)$.

\begin{tabular}{lcc}
\hline $\begin{array}{l}\text { Category of ovulation(s) } \\
\text { by ewe }\end{array}$ & $\mathrm{n}$ & Loss (\%) \\
\hline Single Young & 4 & 0 \\
Single Medium-Aged & 15 & 7 \\
Single Old & 6 & 17 \\
Multiple Young & 5 & 40 \\
Young/Medium-Aged & 11 & 36 \\
Young/Old & 5 & 40 \\
Multiple Medium-Aged & 25 & 56 \\
Medium-Aged/Old & 17 & 35 \\
Multiple Old & 6 & 33 \\
\hline \hline
\end{tabular}


Table 4: Percent of ovulations from follicular wave sources (ultimate $(U)$ and/or penultimate or earlier $(P))$ for ewes scanned by transrectal ultrasonography by location.

\section{Location}

\section{Morgantown, WV Wardensville, WV Dubois, Idaho}

\begin{tabular}{|c|c|c|c|c|c|c|}
\hline Wave Source & $\underline{\mathrm{n}}$ & $\underline{\%}$ & $\underline{\mathrm{n}}$ & \% & $\underline{\mathrm{n}}$ & $\underline{\%}$ \\
\hline Single Ultimate & 14 & 26 & 7 & 37 & 2 & 9 \\
\hline Single Penultimate & 1 & 2 & 1 & 5 & 0 & 0 \\
\hline Multiple Ultimate & 22 & 42 & 6 & 32 & 17 & 77 \\
\hline $\begin{array}{l}\text { MultipleUltimate/ } \\
\text { Penultimate }\end{array}$ & 16 & 30 & 5 & 26 & 2 & 9 \\
\hline Multiple Penultimate & 0 & 0 & 0 & 0 & 1 & 5 \\
\hline
\end{tabular}

Table 5: Association of categories of ovulations from follicular wave sources (ultimate $(U)$ and/or penultimate or earlier $(P)$ ) for ewes scanned by transrectal ultrasonography with embryonic or fetal loss.

Category of ovulation(s)

by ewe

Loss (\%)

Single Ultimate

$\begin{array}{lc}n & \text { Loss }(\%)\end{array}$

Single Penultimate

250

Multiple Ultimate

45

49

Multiple Ultimate/

Penultimate

Multiple Penultimate

10




\section{DISCUSSION}

In the main experiments, neither treatment with $\mathrm{GnRH}$, surgical ablation, nor steroids altered the average duration of the ovulatory follicle on the ovary at $\geq$ $2 \mathrm{~mm}$ or the proportion of ovulations originating from the ultimate or earlier follicular waves.

Although ovulation or atresia of follicles after $\mathrm{GnRH}$ treatment in cattle was associated with the synchronous development of a new follicular wave (Martinez et al., 1999), the three ewes that ovulated early after $\mathrm{GnRH}$ treatment displayed estrus and conceived. Ewes that did not ovulate early after treatment did not have greater regression of ovulatory-sized follicles, nor was the average age of the ovulatory follicle altered.

Little is known about the effects of $\mathrm{GnRH}$ treatment on follicular dynamics other than its use to hasten ovulation in protocols for synchronization of estrus and ovulation in ewes. Effects of $\mathrm{GnRH}$ treatment on anestrous ewes have been highly variable. Some of this variablility may be due to differences in dosage. Although Restall and Radford (1974) found that $50 \mu \mathrm{g} \mathrm{GnRH}$ released sufficient $\mathrm{LH}$ to cause ovulation in 50 to $70 \%$ of lactating ewes, Lopez-Sebastian et al. (1984) did not show an additional effect of $50 \mu \mathrm{g} \mathrm{GnRH}$ to ram introduction in anestrous ewes. Crighton et al. (1973) induced an LH surge and ovulation in most ewes treated with $150 \mu \mathrm{g} \mathrm{GnRH}$ in the anestrous season. Due to the fact that treatment caused ovulation in $25 \%$ of ewes treated ( 3 of 12), and that a 100 $\mu \mathrm{g}$ dosage of $\mathrm{GnRH}$ has been shown to be effective in the cow, it is unlikely that the dosage of $\mathrm{GnRH}$ was too small. It is more likely that $\mathrm{GnRH}$ treatment was 
either given at the wrong time in relationship to the follicular wave in individual ewes, or was simply unable to cause luteinization or atresia of ovulatory-sized follicles on day 11 without causing estrus and ovulation.

Coleman and Dailey (1983) found that it took three to four days after the removal of the preovulatory follicle(s) for another follicle to grow and ovulate in ewes. Ablation of follicles $\geq 4 \mathrm{~mm}$ by electrocautery in this study was not successful in altering the age of the ovulatory follicles. This may be due to the fact that ovulatory follicles in ewes can be recruited from a wide range of sizes. Follicles capable of ovulating can be selected from those $\geq 2 \mathrm{~mm}$ in diameter at luteolysis (Tsonis et al., 1984). Further, true follicular dominance does not seem to exist in the ewe because administration of exogenous $\mathrm{FSH}$ at natural nadirs stimulated additional waves of follicular growth, but did not alter timing of endogenous surges of FSH (Duggavathi et al., 2005).

Results in this study agree with Evans et al. (2002); although removal of the largest follicle in ewes delayed regression of the second largest follicle, new wave emergence occurred at a similar time in treated ewes and control ewes. Time of treatment (day 11) may have corresponded with increasing FSH concentrations and the inititation of a new follicular wave. Ginther et al. (1995) found that in cyclic Polypay ewes, sequential follicular waves emerged, on average, on days $0,5,9$, and 14 of the estrous cycle; however, marked variability in number of waves of follicular growth and days of emergence have been characterized between breeds, and marked within-breed variation was seen in this study. 
Regardless of follicular wave dynamics, follicular ablation may have simply decreased inhibitory factors, such as estrogen and inhibin, or increased stimulatory factors, such as FSH, to promote the growth of follicles $<4 \mathrm{~mm}$ to replace those ablated. In this situation, follicles that normally might be inhibited by presence of larger, ovulatory-sized follicles might be "saved" from atresia and enter into the preovulatory follicular pool.

Treatment with steroids did not alter the mean age or the follicular wave source of the ovulatory follicle. Similar to $\mathrm{GnRH}$, the use of EB and progesterone for altering follicular dynamics has not been well-characterized in the ewe. Preliminary results with the steroid-50 and steroid- 100 treatments showed increased regression of ovulatory-sized follicles in anestrous Suffolk ewes. It may be that anestrous ewes or the Suffolk breed are more sensitive to the effects of EB and progesterone than were the Katahdin cross ewes during the transition between anestrous and the breeding season.

These treatments did not alter pregnancy rate or the total of fertilization failure and embryonic and fetal loss. When the data were reanalyzed by relative age of ovulations without regard to treatment, no association with loss was found for follicles categorized as old, medium, or young in age or follicles originating from the penultimate follicular wave. Thus, embryonic or fetal losses were not associated with ovulation of relatively older follicles in these ewes. Further, based on these analyses, losses were not associated with presence or absence of follicles in any of the categories.

The fact that loss of embryos relative to the number of $\mathrm{CL}$ tended to increase with steroid treatment fits with the observations that increased exposure 
to estrogen increased pregnancy wastage and embryonic abnormalities in the rat (Butcher and Pope, 1979) and loss of pregnancy in the cow (Maurer and Echternkamp, 1982; Pritchard et al., 1994; Thatcher et al., 1989). These observations also fit well into a theory of follicle selection termed "The Lacker Hypothesis" (Lacker et al., 1987): a mathematical model of follicular selection wtih multiple ovulations and anovulatory states similar to those seen in ewes. The model used circulating concentrations of estrogen and gonadotropins to explain growth and atresia of ovulatory-sized follicles; as circulating concentrations of estradiol rise, atresia of more mature follicles increases. Further, for any given stage of follicular maturity, there existed a sufficiently high concentration of estradiol that would cause atresia. This hypothesis might explain situations in which more mature follicles might ovulate even when younger or smaller follicles are growing. It may also explain how estrogen exposure would not necessarily be associated with follicular age, but would vary within biological systems.

Similar to observations in the literature cited, there was significant variation of follicular dynamics within and among breeds (confounded by location). Contrary to our preliminary data in crossbred ewes, the more-prolific Polypay breed did not retain older follicles in order to increase ovulation rate. Instead, results from this experiment show increased recruitment of follicles only days before ovulation in Polypay ewes, so that destruction of what were expected to be penultimate follicles did not alter the age of the ovulatory follicles. This was in direct opposition to the Suffolk and Dorset cross ewes studied in the $\mathrm{GnRH}$ and preliminary follicle cautery experiments. In these experiments, Suffolk and Dorset 
cross ewes tended to have at least one older follicle ovulating as ovulation rate increased. Results seen in the Polypay are in agreement with studies in the pig (Coleman et al., 1984) in which ovarian compensation occurred by an increase in recruitment of growing follicles before ovulation rather than a decrease in atresia. In agreement with other studies, higher loss was associated with multiple rather than single ovulators (Quinlivan et al., 1966; Meyer, 1985; Knights et al., 2003; Dixon et al., 2007). Thirty-eight percent of ewes with multiple ovulations in this study lost partial or total pregnancies compared to $8 \%$ of ewes ovulating singles. There was no association between relative age of follicle or follicular wave source with overall loss or loss type (partial, total). There was an effect of location which was confounded by breed. Unlike findings by Knights et al. (2003) and Dixon et al. (2007), Polypay ewes, which are white-faced, lost more embryos and fetuses than black-faced ewes at Morgantown and Wardensville. This is probably due to the fact that Polypays are known for their superior ovulation rate, and increased ovulation rate is associated with increased loss.

In conclusion, treatment with $\mathrm{GnRH}$, surgical ablation, and steroid treatment on day 10 or 11 did not alter mean age of ovulatory follicle. Older follicles within the age range studied were not detrimental to fertility in ewes. Further, the more prolific Polypay ewes in this study increased ovulation rate by growing more follicles during the last follicular wave rather than retaining older follicles on the ovary. Embryonic loss tended to be greater in association with treatment with estrogen. Cumulatively, one could conclude that estrogen exposure, and not follicular age, may be detrimental to embryonic and fetal survival in the ewe. 


\section{CHAPTER 2: EFFECTS OF EXOGENOUS PROGESTERONE AND LAMB REMOVAL ON ESTROUS RESPONSE AND FERTILIITY IN LACTATING ANESTROUS EWES}

\section{REVIEW OF LITERATURE}

\section{Seasonal Anestrus}

Ewes are seasonally polyestrous. Maximum sexual activity generally occurs in the autumn and early winter months irrespective of the hemisphere, associated with the fact that this timing coincides with the breeding season of wild counterparts of the ewe (reviewed in Hafez, 1952). The incidence of estrus is related inversely to the length of daylight; the peak of estrous cyclic activity coincides with the shortest days (reviewed in Ortavant et al., 1988). Thus, the percentage of ewes displaying estrus is higher during the late summer, fall, and early winter months (McKenzie and Terrill, 1947; Hafez, 1952; Dermody et al., 1970; Mallampati et al., 1971). At the equator, where there is no seasonal fluctuation in the hours of daylight, seasonal sexual activity may be influenced by other factors such as rainfall and nutrition.

Seasonal changes in estrous activity are a consequence of changes in secretion of GnRH (Barrel et al., 1992) and LH (Goodman et al., 1982). A decrease in the frequency of pulsatile secretion of both $\mathrm{GnRH}$ and $\mathrm{LH}$ is thought to be caused by an increase in the sensitivity to negative feedback of estradiol on the hypothalamic-hypophyseal axis (Legan et al., 1977; Legan and Karsch, 1980). The exact mechanism by which increased or decreased sensitivity to estradiol is controlled is unknown, but is likely due in part to changes in the phenotype and activation of specific GnRH afferents (Nunemaker et al., 2002). 
Four main environmental cues are involved with this communication, including changes in nutrition, presence of stressors, photoperiod, and pheromones, all of which help to control when estrous cycles occur. Photoperiodic signals are known to be transduced through duration of pineal secretion of melatonin (reviewed by Goodman and Inskeep, 2006).

Seasonal anestrus is characterized by changes in both estrous activity and occurance of ovulation (reviewed by Knights, 2001). Ovulation rate at estrus follows a similar pattern as estrous cyclic activity, being highest during the breeding season, lowest when estrus is induced during anestrus, and intermediate during transitional periods (Dermody et al., 1970; Mallampati et al., 1971; Hulet et al., 1974; Hall et al., 1986).

As a general rule, fine-wooled breeds and hair sheep tend to be polyestrous throughout most of the year, whereas coarse-wooled breeds are seasonally polyestrous (Asdell, 1946). This is probably due to the environments in which they were developed. Breeds originating from the tropics and Mediterranean region and those with a large percentage of Merino generally have longer breeding seasons than breeds from more temperate latitudes (Whisnant and Inskeep, 1992).

The specific environmental cues and biological and endocrine responses for transition into anestrus have been reviewed (Whisnant and Inskeep, 1992; Knights, 2001; Goodman and Inskeep, 2006). Historically, lactating ewes have not responded to treatments for the induction of estrus that are effective in dry ewes during the anestrous season or in lactating ewes in the estrous season. This review will focus particularly on the lactating ewe in the anestrous season. 


\section{Postpartum Anestrus}

The duration of postpartum anestrus varies with the season of lambing, breed, and presence or absence of lactation and a suckling lamb (reviewed by Mauleon and Flamant, 1975). The duration of postpartum anestrus in the ewe is shortest in those ewes that lamb early rather than late in the breeding season (Hafez, 1952; Mauleon and Dauzier, 1965). Ewes lambing later in the breeding season are faced with the onset of seasonal anestrus. Fertility is particularly low when lactating ewes are bred at induced estrus during anestrus (Cogniè et al., 1975). Whereas $70 \%$ of ewes lambing in fall bred by 44 days postpartum, only $23 \%$ of spring lambing ewes bred with a mean interval to estrus of 66 days postpartum (Whiteman et al., 1972).

\section{Lactation}

Lactation had little or no inhibitory effect on the ability of lle-de-France ewes to exhibit estrous cycles during the breeding season (Mauleon and Dauzier, 1965). Warren et al. (1989) also found no effect of lactational status on conception or fertilization of ewes mated at induced estrus at 30 to 50 days postpartum during the anestrous season.

Yet, the postpartum anestrous interval may be 30 to 40 days in milking ewes and 60 to 80 days among similar ewes that are nursing lambs (Kann and Martinet, 1975). Also, increases in the number of lambs suckling decreased fertilization rate at FGA-PMSG-induced estrus in spring, but the effect was much less during the breeding season (Cognié et al., 1975). Autumn-lambing ewes in 
the normal breeding season returned to estrus, with or without hormonal intervention, and conceived quite readily with 2-month old lambs still nursing (Gordon, 1958, 1975). However, those same sheep had decreased conception rates when nursing lambs in the spring.

Lactation suppressed release of $\mathrm{LH}$ and ovulation in response to ram introduction in anestrous ewes treated with progestogen (Lewis et al., 1974). However, $85 \%$ of ewes showed estrus in response to treatment. LopezSebastian and Inskeep (1988) found that ewes from which lambs were weaned 18 days prior to 12-day progesterone treatment, ram introduction, or both, achieved higher pregnancy rates to first service than ewes weaned on either day 0 or 12 of the treatment period. Knights et al. (2002) found that lactating ewes had lower estrous and conception rates than weaned ewes when progesterone was delivered by used CIDR devices for five days combined with ram introduction in July.

Suppression of lactation immediately after lambing improved fertility more in ewes having born only one lamb than in those with two lambs (Cognié et al., 1974). Further, even after weaning, ewes that raised two lambs had lower conception rates at induced estrus than those that had raised one lamb. When lambs were removed at birth from Dorset-Merino cross ewes, $90 \%$ showed behavioral estrus with ovulation at means of 17 and 34 days postpartum (Restall, 1971). In comparison, only $40 \%$ of ewes with their lambs showed estrus randomly 11 days or later postpartum. Thus, the mean time of ovulation was later in suckling ewes. Similarly, postpartum anestrus averaged longer in duration regardless of time of year for ewes suckling lambs for 42 days compared to ewes 
suckling for one day (Mallampati et al., 1971). Prolonged postpartum anestrus was observed for ewes lambing during the months of seasonal anestrus; however, interaction of suckling and season was not significant in that study. In another experiment, ewes were dried off one or two days after parturition and lambs were reared artificially. This treatment increased fertility at estrus induced 52 days postpartum to $15 \%$ in lle-de-France ewes, but not in the Prealpes du Sud breed (Thimonier et al., 1977), even during seasonal anestrus. Thus, breeds might differ in the importance of inhibition of estrus by the suckling stimulus.

\section{Secretion of Gonadotropins}

Non-suckled ewes had more FSH in their pituitary glands at 21 days postpartum than those that were suckled (Mallampati et al., 1971). However, concentrations of LH did not differ significantly between suckled and non-suckled ewes at this same time period. Suckling reduced $\mathrm{GnRH}$-induced release of $\mathrm{LH}$, but not of $\mathrm{FSH}$, when given at day-25 postpartum (Lewis and Bolt, 1987). The primary mechanism by which suckling and the presence of offspring delays estrus is through a low serum concentration of LH caused by a low frequency of pulsatile secretion of LH (Short et al., 1972, 1990; Williams, 1990). The preovulatory discharge of estrogens and the plasma concentrations of progesterone 10 to 14 days after an induced estrus were lower in nursing ewes than in dry ewes (Cognié et al., 1975). 


\section{Follicular Growth}

Early observers reported that ovaries in anestrous ewes contained follicles with an average diameter as great as that found in breeding ewes (Kammlade et al., 1952). However, Mallampati et al. (1971) found that average diameters of largest follicles in non-suckled ewes were always larger than in suckled ewes, regardless of season. Further, the average diameter of these follicles was significantly smaller in the anestrous season. Oocytes from larger follicles provided better developmental results than those from smaller follicles (e.g. Cognié et al., 1998), so smaller-sized follicles may indicate that lactating ewes in the anestrous season may be induced to ovulate more immature oocytes.

\section{Oocyte Quality}

During anestrus, FGA-PMSG-treated ewes first ovulated 62 hours after progestogen removal regardless of physiological status of the females. However, lactating ewes had more frequent late ovulations than dry ewes (Cognié and Pelletier, 1976). Recovery of segmented eggs upon flushing of oviducts two days after ovulation was decreased significantly in nursing compared to dry ewes, which led Cognié et al. (1975) to suggest that ovum transport may be a problem in the nursing ewe.

Hawk and Conley (1975) showed partial inhibition of sperm transport into the cervix of the ewe and disturbed transport of sperm into the oviducts after progestogen treatment. Warren et al. (1989) found that surgical deposition of semen at the ampullary-isthmus junction significantly improved fertility in day-32 postpartum ewes. However, even though treatment with $\mathrm{PGF}_{2 \alpha}$ in day-32 
postpartum ewes increased uterine contractions toward the oviducts, it did not improve fertility (Kiesling et al., 2000). Therefore, it was speculated that something other than reduced sperm transport limited fertility in early postpartum ewes.

The quality of eggs obtained from nursing ewes was implicated as a primary cause of the decrease in fertility (reviewed in Cognié et al., 1975). The rate of fecundation of eggs was lower in nursing ewes, in association with the spread in time of ovulation and the conditions of sperm transport. Further, a greater number of eggs at day-7 post-ovulation showed a delay in development when placed in vivo into a ligatured oviduct.

Higher embryonic mortality occurred during days 18 to 50 of gestation when eggs from dry ewes were transferred to nursing ewes than when transferred to other dry ewes (Cognié et al., 1975). Foote et al. (1967) found that uterine involution was complete by 23 days postpartum and did not differ between suckled and non-suckled ewes. However, Choffardet (1971) found that the elimination of cellular debris and return to normal uterine weight took place later in spring ( 45 days postpartum) than in autumn ( 30 days). Thus, the quality of the uterine environment may be decreased in lactating ewes in the anestrous season.

\section{Methods of Estrous Synchronization in Lactating Anestrous Ewes Ram Effect}

During the postpartum period, suckling delayed the recovery of cyclic ovarian activity and overt estrous behavior. That delay was reduced when 
suckled ewes were associated with rams (Mauleon and Dauzier, 1965). The induction of ovulation following the association of anovulatory ewes with rams is known as the "ram effect." Underwood et al. (1944) first drew attention to the ram effect when they reported that the anestrous period in Australian Merino ewes was interrupted by ram introduction. It was later demonstrated that introduction of rams could induce ovulation within six days (Schinckel, 1954a). The discontinuous presence of the male prolonged duration of estrous cyclic activity at the end of the breeding season (Riches and Watson, 1954). It is generally accepted that pheromones dependent on androgen stimulation mediate the ram effect in ewes; however, factors other than the absolute amount of androgen are involved, including visual and tactile cues (Watson and Radford, 1960; Signoret, 1976; reviewed in Pearce and Oldham, 1984).

In general, ewes must be anovulatory and have been isolated from rams for a period before they will ovulate in response to ram introduction (Underwood et al., 1944). The precise requirements of isolation have not been quantified, but isolation from the sight and smell of rams for one month is a general recommendation (Oldham, 1980). However, it has been shown that introduction of novel rams to ewes that are already in contact with rams will induce a high proportion of anovulatory ewes to ovulate (Pearce and Oldham, 1988; Cushwa et al., 1992).

Response of ewes to ram introduction, both between and within breeds, is highly variable (Knight, 1983; Martin, 1984). This variability has been equated to the "depth of anestrus" of ewes, which appears to relate to both sensitivity to the negative feedback of steroids and direct effects of photoperiod (Karsch, 1984; 
Thomas et al., 1984). Lindsay and Signoret (1980) found a positive correlation between the proportion of ewes that ovulated spontaneously in the flock (indicating depth of estrus) and the responsiveness of anovulatory ewes in the same flock to ram introduction. The response to the male is influenced further by such factors as breed (Tervit et al., 1977), serving capacity and aggressiveness (Perkins and Fitzgerald, 1994), the immediacy of the contact (Walden-Brown et al., 1993a), and the body condition of the male (Walkden-Brown et al., 1993b).

Although originally thought to directly cause the LH surge, it is now known that ram introduction first increases tonic secretion of LH (Martin and Scaramuzzi, 1983). This increase in tonic LH presumably is a response to increased frequency of secretion of $\mathrm{GnRH}$, and may increase follicular development and subsequent secretion of estradiol to trigger the $\mathrm{LH}$ surge (Atkinson and Williamson, 1985; Goodman and Inskeep, 2006).

Some have reported that the process leading to ovulation is accelerated by 6 to 8 hours in the presence of a male at estrus (Lindsay et al., 1975); however, others (Parsons et al., 1967) found that although the estrus period was shorter when the ram was continuously present, ovulation occurred a mean of six hours later than in ewes that were teased every four hours. The male's presence hastened LH release (Signoret, 1975), but did not influence the interval from LH release to ovulation (Cahill et al., 1974). Most ewes have a preovulatory surge of LH within 48 hours of ram introduction (reviewed by Pearce and Oldham, 1984). Ram introduction should have at least 72 hours of duration for maximum ewe response (Oldham and Pearce, 1983). The first ovulation induced by the introduction of rams is not usually accompanied by estrus (Schinckel, 1954b). 
The corpora lutea $(\mathrm{CL})$ from ovulations induced by ram introduction either persist for a period equivalent to a normal estrous cycle or, more often, regress prematurely (Oldham and Martin, 1978; Knight et al., 1981; Pearce et al. 1985). Ewes with normal CL display estrus about 18 to 19 days after ram introduction. Short-lifespan CL regress after five to six days and ewes have a second ovulation without estrus. The lifespan of $\mathrm{CL}$ following the second silent ovulation is usually normal, so these ewes display estrus approximately 24 days after ram introduction (reviewed by Pearce and Oldham, 1984). However, not all anovulatory ewes were induced to ovulate and some ewes induced to ovulate became anovulatory again before ever displaying estrus (Oldham and Cognié, 1980; Oldham et al., 1985).

\section{Treatment with Progesterone}

A single injection of $20 \mathrm{mg}$ progesterone given up to five days before ram introduction (Lindsay et al., 1984) caused all resulting CL to persist for a normal length of time. In early work, treatment with progesterone did not affect the proportions of anestrous ewes that ovulated, displayed estrus, or ovulated once and then became anovulatory (reviewed in Pearce and Oldham, 1984). However, Knights et al. (2001) found that treatment of anestrous ewes with a progesteronereleasing intravaginal device for either 5 or 12 days in combination with ram introduction was more effective than ram introduction alone to induce estrus and ovulation, and to yield pregnancies. Progesterone impregnated intravaginal sponges or implants were effective to increase response to ram introduction in anovulatory ewes when inserted for as little as five or six days (Pearce and 
Oldham, 1984; Knights et al., 2001) or for the more conventional 12 to 16 days (Hunter et al., 1971; Oldham et al., 1980; Pearce et al., 1984).

$\mathrm{GnRH}$ activity in the hypothalamus was $30 \%$ lower than starting values at the end of a progestogen treatment given to lactating females (Pelletier and Thimonier, 1972), and interval from onset of estrus to $\mathrm{GnRH}$ discharge was increased (Shevah et al., 1974). In the non-breeding season, lactating ewes treated with FGA-PMSG (Pelletier and Thimonier, 1973) or FGA-putrescine (an FSH-releaser; Lewis et al., 1974) had a decreased LH surge compared to dry ewes. The total $\mathrm{LH}$ release in lactating ewes was only $65 \%$ of that in dry ewes. If PMSG was given 12 hours after sponge removal, the LH discharge was improved to $83 \%$ of that of dry ewes (Pelletier and Thimonier, 1975). Similarly, when estrous cycles were blocked by progestogen treatment, a higher proportion of ewes were mated at the end of the treatment when a ram was present during the synchronizing treatment (Hunter, 1968).

\section{Temporary Lamb Removal}

In cattle, short-term calf removal increased conception in synchronized lactating females (Smith et al., 1979; Kiser et al., 1980; Yelich et al., 1995). Similar to early weaning, short-term calf removal decreased the postpartum interval in beef cows and increased mean serum LH concentrations. The use of short-term calf removal in combination with Syncro-Mate-B treatment increased the number of cows detected in estrus and becoming pregnant. Timing of calf removal relative to implant removal did not affect the number of cows showing estrus or conceiving. 
However, the effect of temporary calf removal on the duration of anestrus is variable (Wright et al., 1987; Rivera et al., 1994). Body-condition score (Alberio et al., 1984), duration of calf removal (Shively and Williams, 1989), and interval from calving to calf removal (Bonavera et al., 1990) all may combine to influence the outcome from this treatment. Further, the benefits of calf removal may be age-related, being more beneficial for 3 to 4 -year-old cows than first-calf heifers or older cows (Geary et al., 2001).

The effects of temporary lamb-removal have not been well characterized. D.R. Notter and H.B. Vanimisetti (personal communication) treated lactating ewes in the anestrous season with progesterone followed by ram introduction. They found no difference between ewes with lambs removed for 72 hours at ram introduction and those with no lamb removal in estrous behavior or conception rates. However, 70 to $80 \%$ of the ewes were exhibiting spontaneous estrous cycles based on circulating concentrations of progesterone, and conception rates were high ( $80 \%$ versus $75 \%$, lamb separation versus no separation, respectively) in both groups. 


\section{STATEMENT OF THE PROBLEM}

Improving the number of lambs weaned per ewe is an important source of increased profitability for sheep producers. An increase in lamb numbers can be accomplished in two ways: 1) by increasing the number of lambs born per ewe lambing as described in the previous experiment on aged follicles, or 2) by increasing the number of pregnancies and resulting lambs born per ewe per year. This latter option can be achieved by breeding ewes more than once per year; however, because the ewe is a seasonal breeder, this presents challenges when trying to breed in the anestrous season.

Further, in order to breed and lamb twice in a year or even three times in two years, it may be necessary to rebreed postpartum ewes while they are still nursing lambs. Lactating ewes have not responded to treatments for the induction of estrus that are effective in dry ewes during the anestrous season or in lactating ewes in the fall. Postpartum females have conceived more readily when their lambs were weaned early than when they were lactating. However, early weaning is a labor-intensive practice that is not practical for many farmers.

Temporary calf removal for 48 hours or more increased estrous behavior and conception rates in synchronized lactating cows. It was hypothesized that temporary lamb removal would lead to greater estrous and conception rates in lactating anestrous ewes treated with progesterone and ram introduction. 


\section{MATERIALS AND METHODS}

\section{Animals and Treatments}

Studies were conducted in April and May of 2003 and 2005. Lactating

ewes 26 to 71 days postpartum from two university farms $(N=139)$ were randomized within face color, days in milk, ewe age, and number of lambs suckled into four treatment groups in a $2 \times 2$ factorial arrangement. Farm 1 had crossbred Suffolk and Dorset ewes housed in a barn and fed a corn silage, haylage, and grain mixture. Ewes from Farm 2 were primarily Khatadin, Dorset, and Suffolk crossbreds housed on pasture and supplemented with grain. Both farms were located in West Virginia, USA. Body condition scores (1 to 5) of all ewes were determined by a single person and recorded at the beginning of the experiment. Ewes received $25 \mathrm{mg}$ progesterone either once or twice daily s.c. for five days in April or May of 2003 or 2005. Raddled intact rams were introduced at last progesterone injection with a ewe to ram ratio of 10 or fewer. Lambs were removed from half of the ewes in each group and taken to another barn for 72 hours beginning 12 hours after ram introduction. Grain mixture, hay, and water were provided ad libitum to the lambs during the 72 hours; then they were reintroduced to ewes. Four ewes were removed from experiment due to development of mastitis (not associated with treatment).

Jugular blood samples $(6 \mathrm{ml})$ were collected from all ewes before first progesterone treatment. Blood was kept on ice for transport to the laboratory, allowed to clot at room temperature, and centrifuged for 15 minutes at $1,500 \times \mathrm{g}$. Serum was collected and kept at $-20^{\circ} \mathrm{C}$ until radioimmunoassay for progesterone (Sheffel et al., 1982). Ewes were observed for estrus daily, their ovaries were 
scanned by transrectal ultrasonography approximately eight days after ram introduction for presence and number of CL (Schrick and Inskeep, 1993), and ewes were examined for pregnancy between days 35 and 45 after estrus. Lambing date and number of lambs born were recorded.

\section{Statistical Analysis}

Data were examined for effects of dosage of progesterone (25 or $50 \mathrm{mg}$ ), lamb removal (yes or no) and their interaction, as well as body condition score (BCS; $\leq 2$ or $\geq 2.5$ on a 5 point scale), face color (black, white, or mottled), farm (1 or 2), year (2003 or 2005), days in milk ( $\leq 43$ days or $\geq 44$ days), number of lambs suckled $(1,2$, or 3$)$, and ewe age $(1,2,3$, or $\geq 4)$ by analysis of variance. The GLM procedure of SAS (SAS Institute, Cary, NC) was used to conduct the analysis. Analysis of variance was followed by Duncan's multiple range test when appropriate. Variables examined were number of ewes marked by rams, days from ram introduction to marking, presence of $C L$, number of $C L$ present, pregnancy (diagnosed at ultrasonography), embryonic or fetal loss from pregnancy, ewes lambing, and number of lambs born. 


\section{RESULTS}

All ewes were classified as anestrous prior to ram introduction (progesterone concentrations $<1.0 \mathrm{ng} / \mathrm{ml}$ ). Ninety-two of the 135 ewes treated were marked by rams, but there was no effect of progesterone or lamb removal. The proportion of ewes marked varied with farm, year, and age of ewe $(\mathrm{P}<$ 0.05). Farm 1 had $89 \%$ of ewes marked by rams while Farm 2 had only $45 \%$ ( $P<$ 0.05). In $2003,62 \%$ of ewes were marked by rams, compared to $75 \%$ of ewes in $2005(P<0.05)$. Ewes one year of age had significantly fewer ewes marked by rams $(48 \% ; P<0.05)$ than ewes three $(83 \%)$ or $\geq$ four $(72 \%)$ years old. Occurrence of estrus in ewes two years of age (64\%) was intermediate between the younger and older ewes.

Days from ram introduction to marking tended to differ with dosage of progesterone $(P=0.07)$. Ewes treated with $25 \mathrm{mg}$ progesterone averaged $4.3 \pm$ 0.3 days from ram introduction to marking, while those treated with $50 \mathrm{mg}$ progesterone averaged $5.2 \pm 0.5$ days.

The presence of $C L$ eight days after ram introduction varied significantly with dosage of progesterone, year, and age of the ewe. A greater proportion of ewes treated with $25 \mathrm{mg}$ progesterone had $\mathrm{CL}$ than of ewes treated with $50 \mathrm{mg}$ progesterone $(67 \%$ versus $42 \%$; $P<0.05)$. A greater proportion of ewes had $C L$ in 2005 (60\%) than in 2003 (47\%; P). A lower proportion of one-year-old ewes had CL on day $8(32 \%)$ than of three $(61 \%)$ or $\geq$ four-year-olds $(67 \%)$. Two-year olds (43\%) differed from one and four-year olds and more 3-year-olds had CL than 1-year-olds $(P<0.05)$. The presence of $C L$ tended to be lower $(47 \%)$ in ewes with low body condition score (BCS; $\leq 2)$ than in ewes with high $(\geq 2.5)$ 
BCS $(65 \% ; P=0.06)$. The number of $C L$ per ewe with $C L(1.5 \pm 0.7)$ did not vary with any variable studied.

Pregnancy, as diagnosed between days 35 and 45, varied significantly with face color and days in milk (DIM; P < 0.05), and tended to differ with BCS and number of lambs suckled $(P=0.08,0.05$; respectively). White-faced ewes had more pregnancies (44\%) than mottled-faced ewes (18\%), while black-faced ewes were intermediate (26\%). Ewes less than 44 DIM had significantly fewer pregnancies $(16 \%)$ than ewes 44 DIM or greater $(46 \%$; $P<0.05)$. Ewes with $\geq$ $2.5 \mathrm{BCS}$ tended to have a greater proportion diagnosed pregnant (44\%) than ewes $\leq 2$ BCS $(24 \% ; P=0.08)$. None of the three ewes suckling three lambs were pregnant, while $36 \%$ of 69 ewes suckling one lamb and $29 \%$ of 63 ewes suckling two lambs were diagnosed pregnant $(P=0.05)$.

The proportion of ewes lambing per treated ewe varied with face color and with number of lambs suckled $(P<0.05)$, and tended to differ with location $(P=$ 0.09). A greater proportion of white-faced ewes (33\%) than of mottled-faced ewes $(4 \%, P<0.05)$ lambed, with black-faced ewes being intermediate $(17 \%)$. Twenty six percent of ewes suckling one lamb and $16 \%$ of ewes suckling two lambs lambed to first or second service $(P<0.05)$. Location tended to affect proportion of ewes lambing, $26 \%$ of ewes from Farm 1 and 15\% from Farm 2 ( $P$ $=0.09)$. The number of lambs born per ewe $(1.4 \pm 0.1)$ did not vary with any variable measured. Twenty-three ewes lambed from first service and six lambed from second service.

Total loss of pregnancy from day 35 to 45 to term varied with number of lambs suckled $(P<0.05)$ and tended to vary between dosages of progesterone 
$(P=0.06)$. Of ewes diagnosed pregnant, $38 \%$ of those suckling twins lost pregnancy before lambing, compared to $20 \%$ of ewes suckling singles $(P<0.05)$. Treatment with $50 \mathrm{mg}$ progesterone tended to be associated with greater loss of diagnosed pregnancies $(50 \%)$ than treatment with $25 \mathrm{mg}$ progesterone $(14 \% ; \mathrm{P}=$ 0.06).

Table 6: Variables affecting estrous response from progesterone treatment and ram introduction (RI) in lactating anestrous ewes.

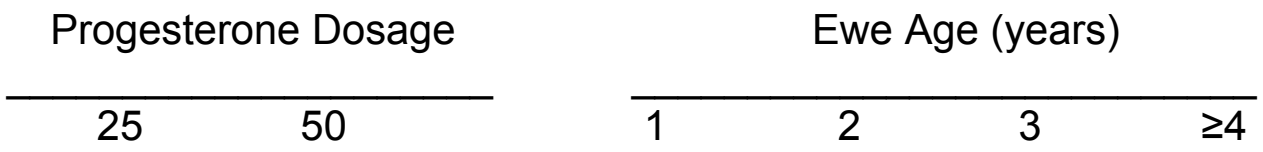

d from Rl to marking

$4.3 \pm 0.3^{a} \quad 5.2 \pm 0.5^{b}$

$5.7 \pm 0.6 \quad 4.6 \pm 0.5 \quad 3.8 \pm 0.3 \quad 5.3 \pm 0.4$

$\%$ marked

by rams

73

65

$48^{\mathrm{c}}$

$64^{\mathrm{c}, \mathrm{d}}$

$83^{d}$

$72^{\mathrm{d}}$

${ }^{a, b}$ Values in a row with different superscripts within variable differ $(P=0.07)$.

${ }^{c, d}$ Values in a row with different superscripts within variable differ $(P<0.05)$. 
Table 7: Variables affecting proportion of ewes with $\mathrm{CL}$ at seven days following ram introduction.

\section{Progesterone Dosage / day}

$25 \mathrm{mg} \quad 50 \mathrm{mg}$

\section{Ewe Age (years)}

\begin{tabular}{llll}
\hline 1 & 2 & 3 & $\geq 4$
\end{tabular}

Body Condition Score (of 5) $\operatorname{low}(\leq 2) \quad \operatorname{high}(\geq 2.5)$

\begin{tabular}{|c|c|c|c|c|c|c|c|c|}
\hline $\begin{array}{l}\% \text { of ewes } \\
\text { with } C L\end{array}$ & $67^{a}$ & $42^{b}$ & $32^{c}$ & $43^{c, d}$ & $61^{\mathrm{d}, \mathrm{e}}$ & $67^{\mathrm{e}}$ & 47 & 65 \\
\hline
\end{tabular}

${ }^{a, b}$ Values in a row with different superscripts within variable differ $(P<0.05)$.

$c, d, e$ Values in a row with different superscripts within variable differ $(P<0.05)$.

$f, g$ Values in a row with different superscripts within variable differ $(P=0.06)$. 
Table 8: Variables affecting proportion of ewes pregnant at pregnancy diagnosis between days 20 to 30 after estrus.

\begin{tabular}{|c|c|c|c|c|c|c|c|c|c|}
\hline \multicolumn{3}{|c|}{ \# Lambs Suckled ${ }^{a}$} & \multicolumn{2}{|c|}{ Days in Milk } & \multicolumn{3}{|c|}{ Face Color } & \multicolumn{2}{|c|}{ Body Condition Score (of 5) } \\
\hline 1 & 2 & 3 & $\leq 43$ & $\geq 44$ & Black & White & Mottled & $\operatorname{low}(\leq 2)$ & high ( $\geq 2.5)$ \\
\hline 36 & 29 & 0 & $16^{b}$ & $46^{c}$ & $26^{\mathrm{d}, \mathrm{e}}$ & $44^{d}$ & $18^{e}$ & $24^{f}$ & $44^{g}$ \\
\hline
\end{tabular}

$\%$ of ewes

pregnant

${ }^{a}$ Values in a row within variable differ $(P=0.05)$

${ }^{b, c}$ Values in a row with different superscripts within variable differ $(P<0.05)$.

d,e Values in a row with different superscripts within variable differ $(P<0.05)$.

$f, g$ Values in a row with different superscripts within variable differ $(P=0.08)$ 
Table 9: Variables affecting the proportion of ewes losing pregnancy of ewes diagnosed pregnant and the proportion of ewes lambing of ewes treated.

$$
\text { Pregnancy loss Ewes lambing of ewes treated }
$$

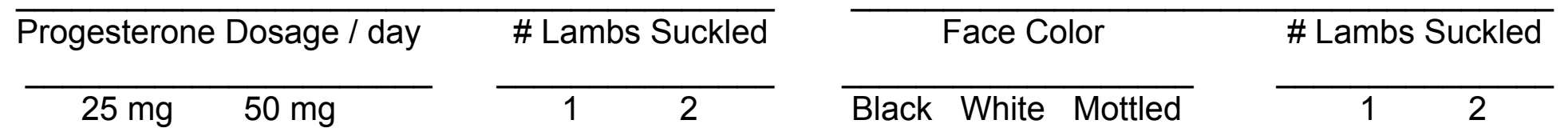

\begin{tabular}{lllllllll}
\hline of ewes $\quad 14^{\mathrm{a}}$ & $50^{\mathrm{b}}$ & $20^{\mathrm{c}}$ & $38^{\mathrm{d}}$ & $17^{\mathrm{e}, \mathrm{f}}$ & $33^{\mathrm{e}}$ & $4^{\mathrm{f}}$ & $26^{\mathrm{g}}$ & $16^{\mathrm{h}}$ \\
\hline
\end{tabular}

${ }^{a, b}$ Values in a row with different superscripts within variable differ $(P=0.06)$

$c, d, e, f, g, h$ Values in a row with different superscripts within variable differ $(P<0.05)$. 


\section{DISCUSSION}

No effect of lamb removal was found on any variable examined. This is in agreement with a study by D.R. Notter and H.B. Vanimisetti (personal communication); however, the current study had significantly lower pregnancy rates than those reported by Notter and Vanimisetti. One reason for the high pregnancy rates seen in their study could have been that 70 to $79 \%$ of the control and treated ewes were already cycling based on circulating progesterone concentrations $>1.0 \mathrm{ng} / \mathrm{ml}$ a few weeks before the study. Their study was done in a flock selected to breed in May. Regardless of cyclicity, lamb removal for 72 hours did not seem to be a viable method of improving any of the variables studied.

Ewes in this study lambed in the months of January and February, which are associated with long intervals from parturition to postpartum estrus of 100 days or more (Hafez, 1952; Barker and Wiggins, 1964; Mauleon and Dauzier, 1965). Further, postpartum anestrus averaged longer in duration regardless of time of year for ewes suckling lambs for 42 days compared to ewes suckling for one day (Mallampati et al., 1971). Therefore, because ewes in this study were 26 to 71 days in milk (DIM), it is not surprising that pregnancy varied by DIM and that overall pregnancy rates were variable and relatively low.

That days from ram introduction to marking, proportion of ewes having $C L$ (indicating ovulation), and proportion of ewes losing pregnancy differed by progesterone dosage is not surprising; however, the fact that the lower dosage of progesterone (25 mg/day) gave more favorable results for all three variables is surprising. Improved sperm transport (Hawk and Conley, 1975) and synchrony of 
estrus onset and the LH surge (Lewis et al., 1974; Ven Cleeff et al., 1998) were associated with higher dosages of progesterone in earlier studies in estrous cycling ewes. Lower It may be that the $50 \mathrm{mg}$ dosage of progesterone places too great of an inhibitory effect on $\mathrm{LH}$ at ram introduction and lamb removal when compared to the $25 \mathrm{mg}$ dosage in lactaging ewes.

Mean time from ram introduction until marking was significantly longer in this study ( 4.3 days versus one to two days) than was reported by Robinson and Smith (1967), Robinson et al. (1968), and Knights et al. (2001). These authors reported average intervals from ram introduction to marking between 24 and 50 hours in anestrous ewes. Further, peak estrous response was observed on day 2 after progesterone withdrawal, while day 4 was the day of peak estrous response in this study.

Lactation suppressed release of LH and ovulation in response to ram introduction (Oldham et al., 1980) or treatment with progestogen and ram introduction (Lewis et al., 1974). Lactation may have delayed and/or inhibited the LH surge in ewes in this study. Inhibition of LH by progesterone may also explain why the ewes treated with the higher dosage of progesterone were marked by rams later ( 0.9 days) than those on the lower dosage.

Response of ewes to ram introduction, both between and within breeds, is highly variable (Knight, 1983; Martin, 1984). This variability has been equated to the "depth of anestrus" of ewes, which appears to relate to both sensitivity to the negative feedback of steroids and direct effects of photoperiod (Karsch, 1984; Thomas et al., 1984). Further, many effects varied by location and year, indicating a high degree of variability within most outcomes studied. Some of this 
variability may stem from the fact that location is confounded by breed differences. Ewes on Farm 2 had some Katahdin influence, while ewes on Farm 1 were only wooled breeds of primarily Suffolk and Dorset descent.

It is well known that fine-wooled breeds and hair sheep tend to be polyestrous throughout most of the year, whereas coarse-wooled breeds are seasonally polyestrous (Asdell, 1946). However, proportion of ewes pregnant was lower in the hair-sheep crossbred ewes at Farm 2, meaning that something other than depth of anestrous limited percent of ewes pregnant. As previously mentioned, some breed effects have been noted in the response to lamb removal. It may be that hair sheep have a stronger negative feedback on LH from suckling or presence of lambs than wooled sheep.

Younger ewes had fewer marks by a ram and a lower proportion of ewes with $\mathrm{CL}$ at ultrasonographic scanning. Ewe lambs have a shorter breeding season than mature ewes (Cole and Miller, 1935; Hafez, 1952); thus, they may be "deeper" into anestrous than older ewes and more difficult to stimulate to cycle.

High pregnancy losses were observed in this study. Loss was linearly related to number of lambs suckling. More lambs suckling increased loss of pregnancy. This may be due to a greater suppression of circulating progesterone in ewes eating more to support greater milk production, as has been shown in dairy cows (Sangsritavong et al., 2002). Lower progesterone is known to increase pregnancy loss in ewes (Dixon et al., 2007). Ewes that raised two lambs had lower conception rates at induced estrus than those that had raised one lamb (Cognié et al., 1974). That may indicate either inhibition of the endocrine 
axis or a problem with follicular dynamics, which in turn could be related to concentration of progesterone.

Overall, results from this study showed no differences among treatment groups in estrous response, occurrence of ovulation or ovulation rate, proportion of ewes pregnant or lambing, or number of lambs born per ewe. Due to the intensity of management and handling required for temporary lamb removal, a major improvement would be needed to make it a good option for producers trying to breed their lactating ewes out-of-season. Lamb removal did not affect any variable studied and did not improve any variable above treatment with progesterone alone. Further, contrary to earlier reports (Lewis et al., 1974; Hawk and Conley, 1975; Van Cleeff et al., 1998) greater dosages of progesterone did not increase, and in some cases decreased the response of lactating anestrous ewes to out-of-season breeding. Further research will need to be done in order to find treatments that can facilitate breeding lactating ewes out-of-season. 


\section{CHAPTER 3: LACK OF EFFECT OF TRANSRECTAL ULTRASONOGRAPHY WITH RESTRAINT ON LAMBING RATE AND PROLIFICACY IN EWES}

\section{INTRODUCTION}

The widespread adoption of transrectal real-time ultrasonography as a means of pregnancy detection has led to greater understanding of embryonic/fetal growth and developmental anatomy (Tainturier et al., 1983; Curran et al., 1986a, b). Transabdominal "B" mode real-time ultrasonography has been used in sheep since the early 1980s (Tainturier et al., 1983). The transrectal route allows earlier determination of both pregnancy and number of embryos present than does transabdominal ultrasonography (Kähn et al., 1993).

Hulet (1972) described a rectal abdominal palpation technique using a plastic rod (diameter $1.5 \mathrm{~cm}$, length $50 \mathrm{~cm}$ ) for pregnancy diagnosis, which was easy and inexpensive. However, some abortions and ewe deaths, apparently resulting from rectal damage and subsequent infection, were reported (Morcan, 1973; Plant and Tyrell, 1974; Turner and Hindson, 1975; Trapp and Slyter, 1983). Transrectal ultrasonography of ewes has been used to determine pregnancy losses (Buckrell et al., 1986; Buckrell, 1988; Gearheart et al., 1988; Schrick and Inskeep, 1993; Dixon et al., 2007). The amount of pressure applied to the rectal wall is less for transrectal ultrasonography than for the rectal abdominal palpation technique; however, the typical probe with the transducer is shaped much like Hulet's plastic rod. Therefore, the objective of this study was to determine if transrectal ultrasonography and restraint of ewes for that purpose caused embryonic or fetal death or loss of pregnancy. 


\section{MATERIALS AND METHODS}

\section{Flocks}

Ten production flocks containing both mature ewes and pubertal ewe lambs or yearlings in West Virginia and Virginia were used. A total of 873 ewes (range 27 to 150 per flock) with complete records were retained in these flocks until the end of the study. Data were not available on 44 ewes (20 of which were sold from one flock) due to death, sale before lambing, or incomplete lambing records; however, numbers of incomplete records did not differ among treatments or flocks, and no deaths caused by complications due to treatment were reported. Six flocks were of mixed breeding with primarily hair-sheep descent (mostly Katahdin and Dorper crossbred ewes). Four flocks were wooled sheep, one of purebred polled Dorsets, and three of mixed breeding, primarily Suffolk and Dorset.

Five flocks were bred from May to July (anestrous season), and five flocks were bred during September and October (estrous season). In three flocks bred during the anestrous season, estrus was induced and synchronized by an injection (i.m.) of $25 \mathrm{mg}$ of progesterone in corn oil at ram introduction followed $14 \mathrm{~d}$ later by two injections (i.m.) of $5 \mathrm{mg}$ prostaglandin $\mathrm{F}_{2 \alpha}$ (Lutalyse, Pfizer Animal Health, New York, NY) $3 \mathrm{~h}$ apart. In one anestrous flock, half of the ewes were treated with $25 \mathrm{mg}$ progesterone (i.m.; Sigma Chemical Co., St. Louis Missouri) in corn oil at ram introduction. One anestrous flock was treated by only ram introduction. In two of the five flocks bred during the estrous season, estrus was synchronized by a single injection of $20 \mathrm{mg}$ prostaglandin $F_{2 \alpha} 4 \mathrm{~d}$ after ram 
introduction. Estrus was not synchronized in the other three flocks. Ewes were randomized into control (C, non-examined) and examined $(E)$ groups within flock at the time of diagnosis of pregnancy. Ewes in Flock 2 were assigned at a 2:1 examined to control ratio.

\section{Determination of Pregnancy}

Three ultrasonographers, who had trained together, determined pregnancy: Operator 1 in two anestrous and four estrous flocks; Operator 2 in three anestrous flocks; and Operator 3 in one estrous flock. Operators 1 and 2 counted embryos and fetuses in six flocks. The West Virginia University Animal Care and Use Committee approved all procedures under protocol \#04-0405.

Examined ewes in nine flocks were scanned for pregnancy once between approximately days 25 and 100 post-breeding (day $0=$ ram introduction) by transrectal ultrasonography (Schrick and Inskeep, 1993), and ewes in one flock were scanned twice on approximately days 40 and 60 . Briefly, ewes were placed in dorsal recumbancy in a tilting squeeze chute (Midwest Plan Service, 1982) and a $7.5 \mathrm{MHz}$ transducer designed for human prostate exams (diameter $1.6 \mathrm{~cm}$, length $35.1 \mathrm{~cm}$; Corometrics Medical Systems, Inc., Wallingford, CT) was coated with a carboxymethyl cellulose lubricant and inserted into the rectum. The reproductive tract was visualized using an Aloka 500 ultrasound console (Corometrics Medical Systems, Inc., Wallingford, CT). Pregnancy status was determined by visualization of the embryonic or fetal heartbeat(s) and numbers of embryos or fetuses (in six flocks) were recorded as 1, 2, or 3 or more. Control ewes were run through the handling facilities but were not subjected to rotation in 
the tilting squeeze chute or to pregnancy diagnosis. At lambing, owners/managers of the respective flocks recorded the ewe number, lambing date, and number of lambs born. These records were returned to the authors for analysis.

\section{Statistical Analysis}

Paired group means ( $E$ and $C)$ for percent ewes lambing, lambing rate (number of lambs born per ewe exposed), and prolificacy (number of lambs born per ewe lambing) on a per flock basis were examined by the paired TTEST procedure of SAS (SAS Institute, Cary, NC). The GLM procedure of SAS was used to test for effects of examination, season, and their interaction by analysis of variance. The effects of operator were examined separately because of confounding with season.

The ANOVA procedure of SAS was used to determine differences among operators in E group means for percent ewes lambing, lambing rate, and prolificacy. The MEANS procedure of SAS was used to determine effects of flock on differences between the percentages of $E$ and $C$ ewes lambing within flocks. The GLM procedure of SAS, followed by Duncan's multiple range test when appropriate, was used to test differences in the number of embryos/fetuses lost per $E$ ewe due to flock, operator (1 or 2), or season. Differences were considered significant when $\mathrm{P} \leq 0.05$. 


\section{RESULTS AND DISCUSSION}

Data for percent ewes lambing, lambing rate, and prolificacy for each flock are presented in Table 10. There were no differences between examined $(E)$ and control (C) ewes on a per flock basis for percent of ewes lambing or lambing rate. Prolificacy was slightly greater for the $E$ group $(P=0.05$; overall mean 1.53 versus $1.60, \mathrm{C}$ and $\mathrm{E}$, respectively). Differences in percent lambing between $\mathrm{E}$ and $\mathrm{C}$ ewes did not vary among flocks. These data showed no reduction in any of the factors studied due to examination by ultrasonography.

In sheep, little information is available on the effect of ultrasonography on pregnancy or embryonic loss. The use of transabdominal ultrasonic instruments has been shown to involve less handling and stress for both the animal and the operator than rectal abdominal palpation techniques (Trapp and Slyter, 1983). However, Schrick and Inskeep (1993) noted that daily transrectal ultrasonography using a $7.5 \mathrm{MHz}$ human prostate transducer caused slight rectal bleeding during the first 2 to $3 \mathrm{~d}$ in some ewes, and edema in the rectal wall in all ewes on the second day.

A rectal abdominal palpation technique described by Hulet (1972) using a plastic rod for pregnancy diagnosis with the ewe in either a sloping position $\left(45^{\circ}\right.$ angle, head down) or a horizontal position in a laparotomy cradle was reported to cause some abortions and death of some ewes (Morcan, 1973; Plant and Tyrell, 1974; Turner and Hindson, 1975; Trapp and Slyter, 1983). In one experiment, about half of 511 ewes suffered some form of rectal damage (Tyrell and Plant, 1979). Turner and Hindson (1975) concluded that this method of pregnancy diagnosis was neither safe nor accurate enough to justify any savings dependent 
on more efficient feeding. However, Plant (1980), using a similar technique on 1823 ewes, found no evidence of ewe mortality or abortion. Operator experience reduced the number of perforated recta (Tyrell and Plant, 1979), which may have been a major reason for safety in Plant's (1980) study. Transrectal ultrasonography requires an inflexible shaft similar to the probes used in other pregnancy determination techniques (Hulet, 1972), and some sheep producers have been reluctant to use the technique. However, no observed rectal damage and no ewe deaths were associated with the technique in this or similar studies (Romano et al., 1998; Dixon et al., 2007).

Transrectal pregnancy diagnosis, whether by ultrasound or palpation, often is done with the ewe in dorsal recumbency in a tilting squeeze chute (Lindahl, 1971, 1972; Morcan, 1973; Schrick and Inskeep, 1993) or a laparotomy cradle (Lamond and Urquhart, 1961; Trapp and Slyter, 1983; Romano et al., 1998). No pregnancy or embryonic/fetal loss has been associated specifically with the use of such restraints; however, even after sedation, non-pregnant ewes had elevated plasma concentrations of cortisol for 90 min after being restrained in a cradle for 5 min (Stafford et al., 2006). Bretzlaff (1993) reported that increased incidence of hydrometra in a ewe flock may have been due to the stress of handling during two examinations of pregnancy by ultrasonography, although the authors considered that this may have been a circumstance unique to this particular flock.

Eighty-five percent of exposed ewes lambed in the estrous season, while only $62 \%$ of ewes lambed in the anestrous season $(P<0.05)$. Consequently, the overall lambing rate was 1.28 in the estrous season and 0.98 in the anestrous 
season $(P=0.05)$. There was no difference between seasons in overall prolificacy (1.60 versus 1.53$)$, and no season by treatment interaction for any variable tested. In ewes carrying multiple offspring, individual embryos or fetuses can be lost without loss of the pregnancy (Henning, 1939; Rhind et al., 1980a; Schrick and Inskeep, 1993; Dixon et al., 2007). Greater loss of individual embryos or fetuses has been found in ewes that conceived during an induced spring or summer breeding season when compared to those conceiving during the estrous season (Quinlivan et al., 1966; Lunstra and Christensen, 1981).

Number of embryos/fetuses lost per E ewe on a flock basis ranged from 0.00 to 0.55 with an overall average of 0.18 . One of six flocks scanned by Operator 1 (Flock 9, 0.55; $\mathrm{P}<0.01$ ) lost more embryos or fetuses per examined ewe than the others. Embryonic/fetal loss in treated ewes averaged 0.02 embryos/fetuses lost per E ewe in the estrous season and 0.20 embryos/fetuses lost in the anestrous season $(P<0.05)$. There was no effect of operator on embryonic/fetal loss in E ewes.

In the six flocks in which embryos or fetuses were counted in the E ewes, $19 \%$ (43 of 224 embryos) were not accounted for at lambing. This is in agreement with the mean of $19.6 \%$ loss of all embryos or fetuses from day 25 to parturition found by Dixon et al. (2007) utilizing ultrasonography, and is similar to mean loss estimated by others looking at number of CL or embryos/fetuses not represented by lambs born (Meyer, 1985; Bolet, 1986; Kaulfuss et al., 1996).

Flock means for Operator 2 were statistically different from Operators 1 and 3 for the percent lambing of $E$ ewes exposed $(P<0.01 ; 41 \%$ versus $86 \%$ and $75 \%)$ and the lambing rate of $E$ ewes exposed $(P=0.01 ; 0.62$ versus 1.41 
and 1.22). However, there was no effect of operator (1,2, or 3$)$ on prolificacy of $E$ ewes $(1.64,1.51$ and 1.63 , respectively). There was no effect of operator on percent $E$ ewes lambing of ewes diagnosed pregnant and no operator by treatment interaction for any variable. Accuracy and success with ultrasonography have been associated with overall operator experience as well as access of the operator to an expert (Logue et al., 1987). Although some effects of operator were found in this study, these could not be distinguished from seasonal effects, because Operator 2 scanned only flocks bred in the anestrous season, Operator 3 scanned only one flock bred in the estrous season, while Operator 1 scanned flocks bred in both seasons.

By implementing appropriate management decisions, producers can potentially minimize reproductive losses if the pregnancy status of the ewe and gestational age and number of fetuses can be determined accurately (White and Russel, 1984). An additional advantage of ultrasonography is the possible detection of fetal death or abnormality (Fredriksson et al., 1986). Furthermore, the speed, ease, and accuracy of transrectal ultrasonography make it an attractive option for early pregnancy detection. Ewes in this study subjected to transrectal ultrasonography in a tilting squeeze chute had similar pregnancy rates, lambing rates, and prolificacy to control ewes in the same flocks. Based on these data, the combination of transrectal ultrasonography with restraint is safe for pregnancy diagnosis in ewes. 
Table 10: Summary of values and means within flocks for examined ewes (E; undergoing restraint and transrectal ultrasonography) and control ewes (C).

\begin{tabular}{|c|c|c|c|c|c|c|c|c|c|}
\hline \multirow[t]{2}{*}{ Flock } & \multicolumn{2}{|c|}{$n^{a}$} & \multirow{2}{*}{$\begin{array}{c}\% \\
\text { Pregnant }^{\mathrm{C}} \\
\text { E }\end{array}$} & \multicolumn{2}{|c|}{$\begin{array}{l}\% \text { Ewes } \\
\text { lambing of } \\
\text { ewes } \\
\text { exposed }\end{array}$} & \multicolumn{2}{|c|}{$\begin{array}{l}\text { Lambing } \\
\text { rate (lambs } \\
\text { born/ewe } \\
\text { exposed) }\end{array}$} & \multicolumn{2}{|c|}{$\begin{array}{c}\text { Prolificacy } \\
\text { (lambs } \\
\text { born/ewe } \\
\text { lambing) }\end{array}$} \\
\hline & C & $E$ & & $C$ & $E$ & C & $E$ & C & $\mathrm{E}$ \\
\hline \multicolumn{10}{|l|}{$\begin{array}{c}\text { Anestrous } \\
\text { season }\end{array}$} \\
\hline 1 & 48 & 45 & 33 & 40 & 33 & 0.52 & 0.47 & 1.32 & 1.40 \\
\hline $2^{b}$ & 27 & 60 & 43 & 100 & 37 & 1.59 & 0.57 & 1.59 & 1.55 \\
\hline 3 & 68 & 42 & 67 & 53 & 52 & 0.79 & 0.83 & 1.50 & 1.59 \\
\hline 4 & 73 & 42 & 81 & 42 & 76 & 0.59 & 1.02 & 1.39 & 1.34 \\
\hline 5 & 44 & 38 & 97 & 95 & 95 & 1.66 & 1.79 & 1.74 & 1.89 \\
\hline Mean & 52 & 45 & 64 & 66 & 59 & 1.03 & 0.94 & 1.51 & 1.55 \\
\hline \multicolumn{10}{|l|}{$\begin{array}{l}\text { Estrous } \\
\text { season }\end{array}$} \\
\hline 6 & 14 & 13 & 85 & 86 & 85 & 1.50 & 1.69 & 1.75 & 2.00 \\
\hline 7 & 74 & 76 & 83 & 81 & 75 & 1.22 & 1.22 & 1.50 & 1.63 \\
\hline 8 & 18 & 29 & 83 & 94 & 79 & 1.33 & 1.17 & 1.41 & 1.48 \\
\hline 9 & 50 & 51 & 84 & 72 & 80 & 1.08 & 1.29 & 1.50 & 1.61 \\
\hline 10 & 37 & 24 & 100 & 95 & 100 & 1.49 & 1.50 & 1.57 & 1.50 \\
\hline Mean & 39 & 39 & 87 & 86 & 84 & 1.32 & 1.37 & 1.55 & 1.64 \\
\hline Overall mean & 45 & 42 & 76 & 76 & 71 & 1.18 & 1.16 & 1.53 & 1.60 \\
\hline Total & 453 & 420 & & & & & & & \\
\hline
\end{tabular}

\footnotetext{
${ }^{a}$ Numbers of ewes that were assigned to treatment and retained until completion of the study.

${ }^{\mathrm{b}}$ Ewes in this flock were randomized at a 2:1 ratio of examined to control.

'Percent of examined ewes that were diagnosed pregnant at time of ultrasonography.

${ }^{\mathrm{d}}$ Groups differed $(P=0.05)$.
} 


\section{LITERATURE CITED}

Adams, G.P., Matteri, R.L., Ginther, O.J. 1992. Effect of progesterone on ovarian follicles, emergence of follicular waves and circulating follicle-stimulating hormone in heifers. J. Reprod. Fertil. 95:627-640.

Adams, T.E., Quirke, J.F., Hanrahan, J.P., Adams, B.M., Watson, J.G. 1988. Gonadotrophin secretion during the periovulatory period in Galway and Finnish Landrace ewes and Finnish Landrace ewes selected for high ovulation rate. J. Reprod. Fert. 83:575-584.

Ahmad, N., Schrick, N., Butcher, R.L., Inskeep, E.K. 1995. Effect of persistent follicles on early embryonic losses in beef cows. Biol. Repro. 52:1129-1135.

Ahmad, N., Townsend, E.C., Dailey, R.A., Inskeep, E.K. 1997. Relationships of hormonal patterns and fertility to occurrence of two or three waves of ovarian follicles, before and after breeding, in beef cows and heifers. Anim. Reprod. Sci. 49(1):13-28.

Akagi, S., Kaneko, H., Nakanishi, Y., Takedomi, T., Watanabe, G., Taya, K. 1997. Ovarian response and FSH profile in cows following injection of various doses of inhibin antiserum. J. Vet. Med. Sci. 59:1129-1135.

Akbar, A.M., Nett, T.M., Niswender, G.D. 1974. Metabolic clearance and secretion rates of gonadotrophins at different stages of the estrous cycle in ewes. Endocrinology 94:1318-1324.

Alberio, R.H., Butler, H.M., Palma, G., Schiersmann, G., Algorta, D., Ortiz, A. 1984. Reproductive behaviour and fertility after a temporary weaning in multiparous beef cows with different body condition. Rev. Arg. Prod. Anim. 4:555-566.

Anderson, L.H., Day, M.L. 1994. Acute progesterone administration regresses persistent dominant follicles and improves fertility of cattle in which estrus was synchronized with melengestrol acetate. J. Anim. Sci. 72:2955-2961.

Anderson, L.H., Day, M.L. 1998. Development of a progestin-based estrus synchronization program: I. Reproductive response of cows fed melengestrol acetate for 20 days with an injection of progesterone. J. Anim. Sci. 76:12671272.

Armstrong, D.T., Pfitzer, A.P., Warnes, G.M., Seamark, R.F. 1983. Superovulation treatments and embryo transfer in Angora goats. J. Reprod. Fertil. 67:403-410.

Asdell, S.A. 1946. Patterns of Mammalian Reproduction. p. $360 \mathrm{New}$ York:Comstock. 
Atkinson, S., Williamson, P. 1985. Ram-induced growth of ovarian follicles and gonadotrophin inhibition in anoestrous ewes. J Reprod. Fertil. 73:185-189.

Barker, H.B., E.L. Wigginis. 1964. Estrual activity in lactating ewes. J. Anim. Sci. 23:973-980.

Barrel, G.K., Moenter, S.M., Caraty, A., Karsch, F.J. 1992. Seasonal changes of gonadotropin-releasing hormone secretion in the ewe. Biol. Reprod. 46:11301135.

Barret, D.M.W, Bartlewski, P.M., Duggavathi, R., Davies, K., Rawlings, N.C. 2006. Suppression of follicle wave emergence in cyclic ewes by supraphysiological concentrations of estradiol-17beta and induction with a physiological dose of exogenous ovine follicle-stimulating hormone. Biol. Reprod. 75:633-641.

Bartlewski, P.M., Beard, A.P., Cook, S.J., Chandolia, R.K., Honaramooz, A., Rawlings, N.C. 1999. Ovarian antral follicular dynamics and their relationships with endocrine variables throughout the oestrous cycle in breeds of sheep differing in prolificacy. J. Repro. Fertil. 115:111-124.

Bartlewski, P.M., Duggavathi, R., Aravindakshan, J., Barrett, D.M.W., Cook, S.J., Rawlings, N.C. 2003. Effects of a 6-day treatment with medroxyprogesterone acetate after prostaglandin $\mathrm{F}_{2 \alpha}$-induced luteolysis in midcycle on antral follicular development and ovulation rate in nonprolific western while-faced ewes. Biol. Reprod. 68:1403-1412.

Beal, W.E., Chenault, J.R., Day, M.L., Corah, L.R. 1988. Variation in conception rates following synchronization of estrus with melengestrol acetate and prostaglandin F2a. J. Anim. Sci. 66:599-602.

Beard, A.J., Castillo, R.J., McLeod, B.J., Glencross, R.J., Knight, P.G. 1990. Comparison of the effects of crude and highly purified bovine inhibin ( $\mathrm{Mr} 32,000)$ on plasma concentrations of FSH and LH in chronically ovariectomized prepubertal heifers. J. Endocrinol. 125:21-30.

Bentley, D.M., Martinez, M., Mitchell, B., Carruthers, T. 1998. LH release, dominant follicle response and wave emergence: The effect of three commercial $\mathrm{GnRH}$ products. Theriogenology 49:338. (Abstract)

Bergfelt, D.R., Kulick, L.J., Kot, K., Ginther, O.J. 2000. Follicular and hormonal response to experimental suppression of $\mathrm{FSH}$ during follicle deviation in cattle. Theriogenology 54:1191-1206.

Bergfelt, D.R., Lightfoot, K.C., Adams, G.P. 1994. Ovarian synchronization following ultrasound-guided follicular ablation in heifers. Theriogenology 42:895907. 
Bindon, B.M., Blanc, M.R., Pelletier, J., Terqui, M., and Thimonier, J. 1979. Periovulatory gonadotrophin and ovarian steroid patterns in sheep of breed with different fecundity. J. Reprod. Fertil. 55:15-25.

Bindon, B.M., Ch'ang, T.S., Turner, H.N. 1971. Ovarian response to gonadotrophin by Merino ewes selected for fecundity. Aust. J. Agric. Res. 22:809-820.

Bleach, E.C.L., Glencross, R.G., Knight, P.G. 2004. Association between ovarian follicle development in dairy cows undergoing spontaneous oestrous cycles. Reproduction 127:621-629.

Bo, G.A., Adams, G.P., Caccia, M., Martinez, M., Pierson, R.A., Mapletoft, R.J. 1995a. Ovarian follicular wave emergence after treatment with progestogen and estradiol in cattle. Anim. Reprod. Sci. 39:193-204.

Bo, G.A., Adams, G.P., Nasser, L.F., Pierson, R.A., Mapletoft, R.J. 1993. Effect of estradiol valerate on ovarian follicles, emergence of follicular waves and circulating gonadotropins in heifers. Theriogenology 40:225-239.

Bo, G.A., Adams, G.P., Pierson, R.A., Tribulo, H., Caccia, M., Mapletoft, R.J. 1994. Follicular wave dynamics after estradiol-17 $\beta$ treatments of heifers with or without a progestogen implant. Theriogenology 41:1555-1569.

Bo, G.A., Adams, G.P., Pierson, R.A., Mapletoft, R.J. 1995b. Exogenous control of follicular wave emergence in cattle. Theriogenology 43:31-40.

Bo, G.A., Caccia, M., Martinez, M.F., Mapletoft, R.J. 1996. Follicle emergence after treatment with estradiol benzoate and CIDR-B devices in beef cattle. Proc. Internat. Cong. Anim. Reprod. 2:22 (Abstract).

Bo, G. A., Pierson, R.A., Mapletoft, R.J. 1991. The effect of estradiol valerate on follicular dynamics and superovulatory response in cows with syncro-mate-B implants. Theriogenology 36:169-183.

Bolet, G. 1986. Timing and extent of embryonic mortality in pigs, sheep and goats: Genetic variability. In: Sreenan, J.M., Diskin, M.G. (eds.), Embryonic Mortality in Farm Animals. Dordrecht, Boston, MA, pp.12-43.

Bonavera, J.J., Schiersmann, G.C.S., Alberio, R.H., Mestre, J. 1990. A note on the effects of 72-hour calf removal and/or bull exposure upon postpartum reproductive performance of Angus cows. Anim. Prod. 50:202-206.

Bradford, G.E., Quirke, F.J., Sitorius, P., Tiesnamurti, I.I., Bell, F.L., Fletcher, I.C., Torrell, D.T. 1986. Reproduction in Javanese sheep: evidence for a gene with large effect on ovulation rate and litter size. J. Anim. Sci. 63:418-431. 
Bretzlaff, K.N. 1993. Development of hydrometra in a ewe flock after ultrasonography for determination of pregnancy. J. Am. Vet. Med. Assoc. 203:122-125.

Breuel, K.F., Lewis, P.E., Schrick, F.N., Lishman, A.W., Inskeep, E.K., Butcher, R.L. 1993. Factors affecting fertility in the postpartum cow: role of the oocyte and follicle in conception rate. Biol. Reprod. 48:655-661.

Bridges, P.J., Lewis, P.E., Wagner, W.R., Inskeep, E.K. 1999. Follicular growth, estrus and pregnancy after fixed-time insemination in beef cow treated with intravaginal progesterone inserts and estradiol benzoate. Theriogenology 52:573-583.

Buckrell, B.C. 1988. Applications of ultrasonography in reproduction in sheep and goats. Theriogenology 29:71-84.

Buckrell, B.C., Bonnett, B.N., Johnson, W.H. 1986. The use of real-time ultrasound rectally for early pregnancy diagnosis in sheep. Theriogenology 25:665-673.

Butcher, R.L. 1972. Aberrant ovulation-consequences on fertility and embryonic development. J. Anim. Sci. Supp. 34:39-48.

Butcher, R.L., Pope, R.S. 1979. Role of estrogen during prolonged estrous cycles of the rat on subsequent embryonic death or development. Biol. Reprod. 21:491-495.

Caccia, M., Bo, G.A. 1998. Follicle wave emergence following treatment of CIDR$B$ implanted beef cows with estradiol benzoate and progesterone. Theriogenology 49:341 (Abstract).

Cahill, L.P., Buckmaster, J.M., Cumming, I.A., Parr, R.A., Williams, A.M. 1974. The effect of the presence of a ram on the time of ovulation in ewes. J. Reprod. Fert. 40:475-477.

Campbell, B.K., Baird, D.T. 2001. Inhibin A is a follicle stimulating hormoneresponsive marker of granulose cell differentiation, which has both autocrine and paracrine actions in sheep. J. Endocrinol. 169:333-345.

Carolan, C., Lonergan, P., Monget, P., Monniaux, D., Mermillod, P. 1996. Effect of follicle size and quality on the ability of follicular fluid to support cytoplasmic maturation of bovine oocytes. Mol. Reprod. Dev. 43:477-483.

Choffardet, R. 1971. L'anoestrus de lactation pendant l'anoestrus saisonnier chez la Brebis. Diplôme. De fin d'Etudes, E.N.S.A., Nancy. 
Cognié, Y., Benoit, F., Poulin, N., Khatir, H., Driancourt, M.A. 1998. Effect of follicle size and of the FecB booroola gene on oocyte function in sheep. J. Reprod. Fertil. 112:379-386.

Cognié, Y., Cornu, C., Mauleon, P. 1974. The influence of lactation on fertility of ewes treated during post-partum anoestrus with vaginal sponges impregnated with FGA. Symp. Physio. Reprod. A.I., Thessaloniki, 17-19 mai 1974.

Cognié, Y., Hernandez-Barreto, M., Saumande, J. 1975. Low fertility in nursing ewes during the non-breeding season. Ann. Biol. Anim. Bioch. Biophys. 15:329343.

Cognié, Y., Pelletier, J. 1976. Preovulatory LH release and ovulation in dry and in lactating ewes after pprogestagen and PMSG treatment during the seasonal anoestrum. Ann. Biol. Anim. Bioch. Biophys. 16:529-536.

Cognié, Y., Poulin, N., Pisselet, C., Monniaux, D. 1995. Effect of atresia on the ability of follicular fluid to support cytoplasmic maturation of sheep oocytes in vitro. Theriogenology 43:188 (Abstract).

Colazo, M.G., Martínez, M.F., Small, J.A., Kastelic, J.P., Burnley, C.A., Ward, D.R., Mapletoft, R.J. 2005. Effect of estradiol valerate on ovarian follicle dynamics and superovulatory response in progestin-treated cattle.

Theriogenology. 63:1454-1468.

Cole, H.H. 1933. Ovogenesis in the ewe and cow. Proc. Soc. Exp. Biol. Med. 31:241-243.

Cole, H.H., Miller, R.F. 1935. Changes in the reproductive organs of the ewe with some data on their control. Am. J. Anat. 57:39-97.

Coleman, D.A., Dailey, R.A. 1983. Effects of repeated removal of large ovarian follicles and treatment with progestin on ovarian function in the ewe. Biol. Reprod. 29:586-593.

Coleman, D.A., Fleming, M.W., Dailey, R.A. 1984. Factors affecting ovarian compensation after unilateral ovariectomy in gilts. J. Anim. Sci. 59:170-176.

Cooperative Regional Research Project, NE-161. 1996. Relationship of fertility to patterns of ovarian follicular development and associated hormonal profiles in dairy cows and heifers. J. Anim. Sci. 74:1943-1952.

Crighton, D.B., Foster, J.P., Haresign, W., Haynes, N.B., Lamming, G.E. 1973. The effects of a synthetic preparation of gonadotopin releasing factor on pituitary and ovarian function in anoestrous ewes. J. Physiol. 231:98-99. 
Cummins, L.J., O'Shea, T., Bindon, B.M., Lee, V.W.K., Findlay, J.K. 1983. Ovarian inhibin content and sensitivity to inhibin in Booroola and control strain Merino ewes. J. Reprod. Fert. 667:1-7.

Curran, S., Pierson, R.A., Ginther, O.J. 1986a. Ultrasonographic appearance of the bovine conceptus from days 10 through 20. J. Am. Vet. Med. Assoc. 189:1289-1294.

Curran, S., Pierson, R.A., Ginther, O.J. 1986b. Ultrasonographic appearance of the bovine conceptus from days 20 through 60. J. Am. Vet. Med. Assoc. 189:1295-1302.

Cushwa, W.T., Bradford, G.E., Stabenfeldt, G.H., Berger, Y.M., Dally, M.R. 1992. Ram influence on ovarian and sexual activity in anoestrous ewes: effects of isolation of ewes before joining and date of ram introduction. J. Anim. Sci. 70:1195-1200.

Custer, E.E., Beal, W.E., Wilson, S.J., Meadows, A.W., Berardinelli, J.G., Adair, R. 1994. Effect of melengestrol acetate (MGA) or progesterone-releasing intravaginal device (PRID) on follicular development, concentrations of estradiol$17 \beta$ and progesterone and luteinizing hormone release during an artificially lengthened bovine estrous cycle. J. Anim. Sci. 72:1282-1289.

Davis, G.H., Bruce, C.D., Dodds, K.G. 2001. Ovulation rate and litter size of prolific Inverdale $\left(F e c X^{1}\right)$ and Hanna $\left(F e c X^{H}\right)$ sheep. Proc. Assoc. Adv. Anim. Breed. Gen. 14:145-178.

Davis, G.H., Galloway, S.M., Ross, I.K., Gregan, S.M., Ward, J., Nimbkar, B.V., Ghalsasi, P.M., Nimbkar, C., Gray, G.D., Subandriyo, Inounu, I., Tiesnamurti, B., Martyniuk, E., Eythorsdottir, E., Mulsant, P., Lecerf, F., Hanrahan, J.P., Bradford, G.E., Wilson, T. 2002. DNA tests in prolific sheep from eight countries provide new evidence on origin of the Booroola (FecB) mutation. Biol. Reprod. 66:18691874.

Dermody, W.C., Foote, W.C., Hulet, C.V. 1970. Effects of season and progesterone synchronization on ovulation rate in mature western range ewes. J. Anim. Sci. 30:214-218.

Dixon, A.B. 2003. Late Embryonic and Fetal Mortality in the Ewe. Ph.D Dessertation, West Virginia University, [On-line Abstract]. Available: https://etd.wvu.edu/etd/etdDocumentData.jsp?jsp_etdID=3042.

Dixon, A.B., Knights, M., Winkler, J.L., Marsh, D.J., Pate, J.L., Wilson, M.E., Dailey, R.A., Seidel, G., Inskeep, E.K. 2007. Patterns of late embryonic and fetal mortality and association with several factors in the sheep. J. Anim. Sci. 85:12741284. 
D'Occhio, M.J.D., Jillella, D., Lindsey, B.R. 1999. Factors that influence follicle recruitment, growth and ovulation during ovarian superstimulation in heifers: opportunities to increase ovulation rate and embryo recovery by delaying the exposure of follicles to LH. Theriogenology 51:9-35.

Driancourt, M.A., Gauld, I.K., Terqui, M., Webb, R. 1986. Variations in patterns of follicle development in prolific breeds of sheep. J. Reprod. Fert. 78:565-575.

Driancourt, M.A., Thuel, B., Mermillod, P., Lonergan, P. 1998. Relationship between oocyte quality measured after IVM, IVF and IVC of individual oocytes and follicle function in cattle. Theriogenology 49:345 (Abstract).

Duggavathi, R., Bartlewski, P.M., Agg, E., Barrett, D.M.W., Rawlings, N.C. 2005. The effect of manipulation of follicle-stimulating hormone (FSH)-peak characteristics on follicular wave dynamics in sheep: does an ovarianindependent endogenous rhythm in FSH secretion exist? Biol. Reprod. 72:14661474.

Duggavathi, R., Bartlewski, P.M., Barrett, D.M.W., and Rawlings, N.C. 2003. Use of high-resolution transrectal ultrasonography to assess changes in numbers of small ovarian antral follicles and their relationships to the emergence of follicular waves in cyclic ewes. Theriogenology 60:495-510.

Dutt, R.H., Casida, L.E. 1948. Alteration of the estrual cycle in sheep by use of progesterone and its effect upon subsequent ovulation and fertility.

Endocrinology 43:208-217.

Engelhardt, H., Walton, J.S., Miller, R.B., King, G.J. 1989. Estradiol-induced blockade of ovulation in the cow: effects on luteinizing hormone release and follicular fluid steroids. Biol. Reprod. 40:1287-1297.

Evans, A.C.O. 2003. Ovarian follicle growth and consequences for fertility in sheep. Anim. Reprod. Sci. 78:289-306.

Evans, A.C.O, Flynn, J.D., Duffy, P., Knight, P.G., Boland, M.P. 2002. Effects of ovarian follicle ablation on $\mathrm{FSH}$, oestradiol and inhibin A concentrations and growth of other follicles in sheep. Reproduction 123:59-66.

Evans, A.C., Flynn, J.D., Quinn, K.M., Daffy, P., Quinn, P., Madgwick, S., Crosby, T.F., Boland, M.P., Beard, A.P. 2001. Ovulation of aged follicles does not affect embryo quality or fertility after a 14-day progestagen estrus synchronization protocol in ewes. Theriogenology 15:923-936.

Evans, J.S., Dutt, R.H., Simpson, E.C. 1962. Breeding performance in ewes after synchronizing estrus by feeding 6-methyl-17-acetoxyprogesterone. J. Anim. Sci. 21:804-808. 
Fair, S., Hanrahan, J.P., Donovan, A., Duffy, P., O'Meara, C.M., Lonergan, P., Evans, A.C.O. 2007. Hormonal relationships during the periovulatory period among ewe breeds of different fertility after cervical artificial insemination with frozen-thawed semen. Anim. Reprod. Sci. 97:284-294.

Fair, S., Hanrahan, J.P., O'Meara, C.M., Duffy, P., Rizos, D., Wade, M., Donovan, A., Boland, M.P., Lonergan, P., Evans, A.C.O. 2005. Differences between Belclare and Suffolk ewes in fertilization rate, embryo quality and accessory sperm number after cervical or laparoscopic artificial insemination. Theriogenology 63:1995-2005.

Fair, S., Hanrahan, J.P., Ward, F., O'Meara, C.M., Duffy, P., Donovan, A., Lonergan, P., Evans, A.C.O. 2006. The difference in embryo quality between Belclare and Suffolk ewes is not due to differences in oocyte quality. Theriogenology 66:191-197.

Findlay, J.K. 1994. Peripheral and local regulators of folliculogenesis. Reprod. Fertil. Dev. 6:127-139.

Findlay, J.K., Cumming, I.A. 1976. FSH in the ewe: effects of season, liveweight and plane of nutrition on plasma FSH and ovulation rate. Biol. Reprod. 15:335342.

Flynn, J.D., Duffy, P., Boland, M.P., Evans, A.C. 2000. Progestagen synchronization in the absence of a corpus luteum results in the ovulation of a persistent follicle in cyclic ewe lambs. Anim. Reprod. Sci. 62:285-296.

Fogwell, R.L., Kanyima, B.M., Villa-Godoy, A., Enright, W.J., Ireland, J.J. 1986. Enhanced precision of estrus and luteinizing hormone after progesterone and prostaglandin in heifers. J. Dairy Sci. 69:2179-2185.

Folman, Y., Rosenberg, M., Herz, Z., Davidson, M. 1973. The relationship between plasma progesterone concentrations and conception in postpartum dairy cows maintained on two levels of nutrition. J Reprod Fertil. 34:267-278.

Foote, W.C., Call, J.W., Hulet, C.V. 1967. Effects of lactation and hormone treatment on ovulations estrus and uterine involution in the ewe. J. Anim. Sci. 26:943 (Abstract).

Ford, S.P., Weems, C.W., Pitts, R.E., Pexton, J.E., Butcher, R.L., Inskeep, E.K. 1975. Effects of estradiol-17beta and progesterone on prostaglandins $F$ in sheep uteri and uterine venous plasma. J. Anim. Sci. 41:1407-1413.

Fredriksson, G., Asp, M., Siwertsson, C-G. 1986. Dräktighetsdiagnostik på tacka med hjälp av ultraljud. Svensk. Veterinärtidning. 38:79-84. 
Fricke, P.M., Guenther, J.N., Wiltbank, M.C. 1998. Efficacy of decreasing the dose of $\mathrm{GnRH}$ used in a protocol for synchronization of ovulation and timed $\mathrm{Al}$ in lactating dairy cows. Theriogenology 50:1275-1284.

Fugo, N.W., Butcher, R.L. 1966. Overripeness and the mammalian ova I. Overripeness and early embryonic development. Fertil. and Steril. 17:804-814.

Galloway, S.M., McNatty, K.P., Cambridge, L.M., Laitinen, M.P.E., Juengel, J.L., Jokiranta, T.S., McLaren, R.J., Luiro, K., Dodds, K.G., Montgomery, G.W., Beattie, A.E., Davis, G.H., Ritvos, O. 2000. Mutations in an oocyte-derived growth factor 15 (BMP15) cause increased ovulation rate and infertility in a dosage-sensitive manner. Nat. Gen. 25:279-283.

Gastal, E.L., Gastal, M.O., Bergflet, D.R., Ginther, O.J. 1997. Role of diameter differences among follicles in selection of a future dominant follicle in mares. Biol. Reprod. 57:1320-1327.

Gearheart, M.A., Wingfield, W.E., Knight, A.P., Smith, J.A., Dargatz, D.A., Boon, J.A., Stokes, C.A. 1988. Real-time ultrasonography for determining pregnancy status and viable fetal numbers in ewes. Theriogenology 30:323-377.

Geary, T.W., Whittier, J.C., Hallford, D.M., MacNeil, M.D. 2001. Calf removal improves conception rates to the Ovsynch and CO-Synch protocols. J. Anim. Sci. $79: 1-4$

Gibbons, J.R., Kot, K., Thomas, D.L., Wiltbank, M.C., Ginther, O.J. 1999. Follicular and FSH dynamics in ewes with a history of high and low ovulation rates. Theriogenology 52:1005-1020.

Ginther, O.J., Beg, M.A., Bergfelt, D.R., Donadeu, F.X., Kot, K. 2001a. Follicle selection in monovular species. Biol. Reprod. 65:638-647.

Ginther, O.J., Bergfelt, D.R., Beg, M.A., Kot, K. 2001b. Follicle selection in cattle: role of luteinizing hormone. Biol. Reprod. 64:197-205.

Ginther, O.J., Bergfelt, D.R., Kulick, L.J., Kot, K. 1998. Pulsatility of systemic $\mathrm{FSH}$ and $\mathrm{LH}$ concentrations during follicular-wave development in cattle. Theriogenology 50:507-519.

Ginther, O.J., Kastelic, J.P., Knopf, L. 1989. Composition and characteristics of follicular waves during the bovine estrous cycle. Anim. Reprod. Sci. 20:187-200.

Ginther, O.J., Kot, K., Wiltbank, M.C. 1995. Associations between emergence of follicular waves and fluctuations in $\mathrm{FSH}$ concentrations during the oestrous cycle in ewes. Theriogenology 43:689-703.

Glencross, R.G., Bleach, E.C., Wood, S.C., Knight, P.G. 1994. Active immunization of heifers against inhibin: effects on plasma concentrations of 
gonadotrophins, steroids and ovarian follicular dynamics during prostaglandinsynchronized cycles. J. Reprod. Fertil. 100:599-605.

Gonzalez-Bulnes, A., Garcia-Garcia, R.M., Souza, C.J.H., Santiago-Moreno, J., Lopez-Sebastian, A., Cocero, M.J., Baird, D.T. 2002. Patterns of follicular growth in superovulated sheep and influence on endocrine and ovarian response.

Reprod. Dom. Anim. 37:357-361.

Goodman, R.L., Bittman, E.L., Foster, D.L., Karsch, F.J. 1982. Alterations in the control of luteinizing hormone pulse frequency underlie the seasonal variation in estradiol negative feedback in the ewe. Biol. Reprod. 27:580-589.

Goodman, R.L., Inskeep, E.K. 2006. Neuroendocrine control of the ovine estrous cycle. Knobil, E. and Neill, J.D. The Physiology of Reproduction. 3rd[47], pp. 2389-2447. New York, Raven Press.

Gordon, I. 1958. Studies in the extra-seasonal production of lambs. J. Agric. Sci. Camb. 50:152-196.

Gordon, I. 1975. Hormonal control of reproduction in sheep. Proc. Br. Soc. Anim. Prod. 4:79-93.

Hafez, E.S.E. 1952. Studies on the breeding season and reproduction of the ewe. J. Ag. Sci. 42:189-265.

Hall, D.G., Forgarty, N.M., Gilmour, A.R. 1986. Seasonality of ovulation and estrus, and the ram effect in poll dorset ewes. Theriogenology 25:455-461.

Hanrahan, J.P. 1976. Repeatability of ovulation rate and its relationship with litter size in four sheep breeds. Proc. 27th Ann. Meeting E.A.A.P. (Zurich) G30:1-8.

Hawk, H.W., Bolt, D.J. 1970. Luteolytic effect of estradiol-17 $\beta$ when administered after midcycle in the ewe. Biol. Reprod. 2:275-278.

Hawk, H.W., Conley, H.H. 1975. Involvement of the cervix in sperm transport failures in the reproductive tract of the ewe. Biol. Reprod. 13:322-328.

Henning, W.L. 1939. Prenatal and postnatal sex ratio in sheep. J. Agric. Res. 58:565-579.

Hogue, D.E., Hansel, W., Bratton, R.W. 1962. Fertility of ewes bred naturally and artificially after estrous cycle synchronization with an oral progestational agent. J. Anim. Sci. 21:625-627.

Hulet, C.V. 1972. A rectal abdominal palpation technique for diagnosing pregnancy in the ewe. J. Anim. Sci. 35:814-819. 
Hulet, C.V, Shelton, M., Gallagher, J.R., Price, D.A. 1974. Effects of origin and environment on reproductive phenomena in Rambouillet ewes. I. Breeding season and ovulation. J. Anim. Sci. 38:1210-1217.

Hulet, C.V., Voightlander, H.P., Pope, A.L., Casida, L.E. 1956. The nature of early-season infertility in sheep. J. Anim. Sci. 15:607-616.

Hunter, G.L. 1968. Increasing the frequency if oregnancy in sheep, 1. Some factors affecting rebreeding during the post-partum period. Anim. Breed. Abs. 36:347-378.

Hunter, G.L., Belonje, P.C. and van Niekirk, C.H. 1971. Synchronized mating and lambing in spring-bred Merino sheep: the use of progestogen-impregnated intravaginal sponges and teaser rams. Agroanimalia 3:133-140.

Inskeep, E.K. 2004. Preovulatory, postovulatory, and postmaternal recognition effects of concentrations of progesterone on embryonic survival in the cow. J. Anim. Sci. 82(E. Suppl.):E24-E39.

Inskeep, E.K., Dailey, R.A. 2005. Embryonic death in cattle. Vet. Clin. N. Amer., Food Anim. Prac. 21:437-461.

Johnson, S.K., Dailey, R.A., Inskeep, E.K., Lewis, P.E. 1996. Effect of peripheral concentrations of progesterone on follicular growth and fertility in ewes. Dom. Anim. Endocrin. 13:69-79.

Kähn, W., Achtzehn, J., Kähn, B., Richter, A., Schulz, J., Wolf, M. 1993. Zur sonographie der gravidität bei schafen. II. Genauigkeit der transrektalen und der transkutanen träachtigkeitsdiagnose. Dtsch. tierärztl. Wschr. 100:29-31.

Kammlade, W.G., Welch, J.A., Nalbandov, A.V., Norton, H.W. 1952. Pituitary activity of sheep in relation to the breeding season. J. Anim. Sci. 11:646-655.

Kann, G., Martinet, I. 1975. Prolactin levels and duration of post-partum anoestrus in lactating ewes. Nature. 257:63-64.

Karsch, F.J. 1984. The hypothalamus and anterior pituitary gland. In:Austin C.R., Short, R.V. (eds), Reproduction in Mammals: 3 Hormonal Control of Reproduction, $2^{\text {nd }}$ edn, pp.1-20. Cambridge University Press, Cambridge.

Kastelic, J.P., Ko, J.C.H., Ginther, O.J. 1990. Suppression of dominant and subordinate ovarian follicles by a proteinaceous fraction of follicular fluid in heifers. Theriogenology 34:499-509.

Kaulfuss, K.H., Uhlich, K., Brabant, S., Blume, K., Strittmatter, K. 1996. Die ultrasonographische trächtigkeitsdiagnostik (B-mode) beim schaf. Tierärztl Prax 24:443-452. 
Kiesling, D.O., Akinbami, M.A., Meredith, S., Warren Jr., J.E. 2000. Uterine contraction patterns and fertility in early postpartum ewes. Sm. Rum. Res. 38:5156 .

Kiser, T.E., Dunlap, S.E., Benyshek, L.L., Mares, S.E. 1980. The effect of calf removal on estrous response and pregnancy rate of beef cows after SyncroMate-B treatment. Theriogenology 13:381-389.

Knight, T.W. 1983. Ram induced stimulation of ovarian and estrous activity of anoestrous ewes - a review. Proc. NZ Soc. Anim. Prod. 43:7-11.

Knight, T.W., Tervit, H.R., Fairclough, R.J. 1981. Corpus luteum function in ewes stimulated by rams. Theriogenology 15:183-190.

Knights, M. 2001. Induction of fertile estrus during seasonal anestrus in ewes and fall born ewe lambs. Dissertation, West Virginia University, Morgantown, WV.

Knights, M, Baptiste, Q.S., Lewis, P.E. 2002. Reproductive performance of anestrous ewes treated with used CIDR devices and estrogen. J. Anim. Sci. 80:75 (Abstract).

Knights, M., Baptiste, Q.S., Dixon, A.B., Pate, J.L., Inskeep, E.K., Lewis, P.E. 2003. Effect of dosage of follicle stimulating hormone (FSH), vehicle and time of injection on ovulation rate and prolificacy in anestrous ewes. Sm. Rum. Res. $50: 1-9$.

Knights, M., Hoehn, T., Lewis, P.E., Inskeep, E.K. 2001. Effectiveness of intravaginal progesterone inserts and $\mathrm{FSH}$ for inducing synchronized estrus and increasing lambing rate in anestrous ewes. J. Anim. Sci. 79:1120-1131.

Kojima, F.N., Chenault, J.R., Wehrman, M.E., Bergfeld, E.G., Cupp, A.S., Werth, L.A., Mariscal, V., Sanchez, T., Kittok, R.J., Kinder, J.E. 1995. Melengestrol acetate at greater doses than typically used for estrus synchrony in bovine females does not mimic endogenous progesterone in regulation of secretion of luteinizing hormone and estradiol-17 $\beta$. Biol. Reprod. 52:455-463.

Kulick, L.J., Bergfelt, D.R., Kot, K., Ginther, O.J. 2001. Follicular selection in cattle: I: Follicle deviation and codominance within sequential waves. 65:839-846.

Kusina, N.T., Meyer, R.L., Carlson, K.M., Wheaton, J.E. 1995. Passive immunization of ewes against an inhibin-like peptide increases follicle-stimulating hormone concentrations, ovulation rate, and prolificacy in spring-mated ewes. J. Anim. Sci. 73:1433-1439.

Lacker, H.M., Beers, W.H., Meuli, L.E., Akin, E. 1987. A theory of follicle selection: I. Hypotheses and examples. Biol. Reprod. 37:570-580. 
Lambalk, C.B., Boomsma, D.I., De Boer, L., De Koning, C.H., Schoute, E., PoppSnijders, C., Schoemaker, J. 1998a. Increased levels and pulsatility of folliclestimulating hormone in mothers of hereditary dizygotic twins. J. Clin. Endocrinol. Metab. 83:481-486.

Lamond, D.R., Urquhart, E.J. 1961. Sheep laparotomy cradle. Aust. Vet. J. 37:430-431.

Land, R.B., Pelletier, J., Thimonier, J., Mauleon, P. 1973. A quantitative study of genetic differences in the incidence of oestrus, ovulation and plasma luteinizing hormone concentration in the sheep. J. Endocrinol. 58:305-317.

Larson, G.H., Mallory, D.S., Dailey, R.A., Lewis, P.E. 1991. Gonadotropin concentrations, follicular development, and luteal function in pituitary stalktransected ewes treated with bovine follicular fluid. J. Anim. Sci. 69:4104-4111.

Legan, S.J., Karsch, F.J., Foster, D.L. 1977. The endocrine control of seasonal reproductive function in the ewe: A marked change in response to the negative feedback action of estradiol on luteinizing hormone secretion. Endocrinology 101:818-824.

Legan, S.J., Karsch, F.J. 1980. Photoperiodic control of seasonal breeding in ewes: Modulation of the negative feedback action of estradiol. Biol. Reprod. 23:1061-1068.

Lewis, G.S., Bolt, D.J. 1987. Effects of suckling, progestogen-impregnated pessaries or hysterectomy on ovarian function in autumn-lambing postpartum ewes. J. Anim. Sci. 64:216-225.

Lewis, P.E., Bolt, D.J., Inskeep, E.K. 1974. Luteinizing hormone release and ovulation in anestrous ewes. J. Anim. Sci. 38:1197-1203.

Lindahl, I.L. 1971. Pregnancy diagnosis in the ewe by intrarectal Doppler. J. Anim. Sci. 32:922-925.

Lindahl, I.L. 1972. Early pregnancy detection in ewes by intrarectal reflection echo ultrasound. J. Anim. Sci. 34:772-775.

Lindsay, D.R., Cognié, Y., Pelletier, J., Signoret, J.P. 1975. Influence of the presence of rams on the timing of ovulation and discharge of $\mathrm{LH}$ in ewes.

Physiol. Behav. 15:423-426.

Lindsay, D.R., Gray, S.J., Oldham, C.M., Pearce, D.T. 1984. Alternative methods for synchronization of ewes in spring using the "ram effect." I. The single injection of progesterone. Proc. Aust. Soc. Anim. Prod. 15:159-161.

Lindsay, D.R., Signoret, J.P. 1980. Influence of behaviour on reproduction. Proc. $9^{\text {th }}$ Int. Cong. Anim. Reprod. A.I. 1:83-92. Madrid. 
Logue, D.N., Hall, J.T., McRoberts, S., Waterhouse, A. 1987. Real-time ultrasonic scanning in sheep: the results of the first year of its application on farms in south-west Scotland. Vet. Rec. 121:146-149.

Long, S.E., Williams, C.V. 1980. Frequency of chromosomal abnormalities in early embryos of the domestic sheep (Ovis aries). J. Reprod. Fertil. 58:197-201.

Lopez, H., Sartori, R., Wiltbank, M.C. 2005. Reproductive hormones and follicular growth during development of one or multiple dominant follicles in cattle. Biol. Reprod. 72:788-795.

Lopez-Sebastion, A., Gomez-Brunet, A., Inskeep, E.K. 1984. Effects of a single injection of LHRH on the response of anestrous ewes to the introduction of rams. J. Anim. Sci. 59:277-283.

Lopez-Sebastian, A., Gonzalez de Bulnes, A., Santiago Moreno, J., GomezBrunet, A., Townsend, E.C., Inskeep, E.K. 1997. Patterns of follicular development during the estrous cycle in monovular Merino del Pais ewes. Anim. Reprod. Sci. 48:279-291.

Lopez Sebastian, A., Inskeep, E.K. 1988. Effects of lactation status, progestogen and ram exposure on response to cloprostenol in ewes during the anestrous period. Theriogenology. 30:279-289.

Lunstra, D.D., Christensen, R.K. 1981. Synchronization of ewes during anestrus: influence of time of year and interval to onset of estrus on conception rate. J. Anim. Sci. 53:448-457.

Macmillan, K.L., Day, A.M., Taufa, V.K., Gibb, M., Pearce, M.G. 1985. Effects of an agonist of gonadotrophin-releasing hormone in cattle. I. Hormone concentrations and oestrous cycle length. Anim. Reprod. Sci. 8:203-212.

Macmillan, K.L., Peterson, A.J. 1993. A new intravaginal progesterone releasing device for cattle (CIDR-B) for oestrous synchronization, increasing pregnancy rates and the treatment of post-partum anoestrous. Anim. Reprod. Sci. 33:1-25.

Macmillan, K.L., Thatcher, W.W. 1991. Effects of an agonist of gonadotropinreleasing hormone on ovarian follicles in cattle. Biol. Reprod. 45:883-889.

Madill, S., Reiger, D., Johnson, W.H., Walton, J.S., Coy, D.H., Rawlings, N.C. 1994. Effect of an LHRH antagonist on the time of occurrence and amplitude of the preovulatory LH surge, progesterone and estradiol secretion, and ovulation in superovulated Holstein heifers. Theriogenology 41:951-960.

Malllampati, R.S., Pope, A.L., Casida, L.E. 1971. Effect of suckling on postpartum anestrus in ewes lambing in different seasons of the year. J. Anim. Sci. 32:673-677. 
Martin, G.B., Scaramuzzi, R.J. 1983. The induction of oestrus and ovulation in seasonally anovular ewes by exposure to rams. J. Steroid Biochem. 19:869-875.

Martin, G.B. 1984. Factors affecting the secretion of luteinizing hormone in the ewe. Biol. Rev. 59:1-87.

Martinez, M.F., Adams, G.P., Kastelic, J.P., Bergfelt, D.R., Mapletoft, R.J. 2000. Induction of follicular wave emergence for estrus synchronization and artificial insemination in heifers. Theriogenology 54:757-769.

Martinez, M.F., Kastelic, J.P., Mapletoft, R.J. 2004. The use of estradiol and/or $\mathrm{GnRH}$ in a two-dose PGF protocol for breeding management in beef heifers. Theriogenology 62:363-372.

Martinez, M, Bergfelt, D., Adams, G., Kastelic, J., Mapletoft, R. 1999. Effect of LH or $\mathrm{GnRH}$ on the dominant follicle of the first follicular wave in heifers. Anim. Reprod. Sci. 57:23-33.

Mauleon, P., Dauzier, L. 1965. Variations de la durée de l'anoestrus de lactation chez les brebis de race lle-de-France. Ann. Biol. Anim. Bioch. Biophys. 5:131143.

Mauleon, P., Flamant, J. 1975. Porquoi allaiter artificiellement. In: L'allaitement artificial chez les ovins, Ed. S. E. I.-I. N. R. A., Paris, mars 75.

Maurer, R.R., Echternkamp, S.E. 1982. Hormonal asynchrony and embryonic development. Theriogenology 17:11-22.

McDowell, C.M., Anderson, L.H., Lemenager, R.P., Mangione, D.A., Day, M.L. 1998. Development of a progestin-based estrus synchronization program: I. Reproductive response of cows fed melengestrol acetate for 14 days with injections of progesterone and prostaglandin $F_{2 \alpha}$. J. Anim. Sci. 76:1273-1279.

McKenzie, F.F., Terrill, C.E. 1947. Estrus, ovulation, and related phenomena in the ewe. Mo. Agr. Exp. Sta. Bull. 264.

McNatty, K.P., Juengel, J.L., Wilson, T., Galloway, S.M., Davis, G.H. 2001. Genetic mutations influencing ovulation rate in sheep. Reprod. Fertil. Dev. 13:549-555.

McNatty, K.P., Reader, K., Smith, P., Heath, D.A., Juengel, J.L. 2007. Control of ovarian follicular development to the gonadotrophin-dependent phase: a 2006 perspective. Soc. Reprod. Fertil. Suppl. 64:55-68.

McNatty, K.P., Juengel, J.L., Wilson, T., Galloway, S.M., Davis, G.H., Hudson, N.L., Moeller, C.L., Cranfield, M., Reader, K.L., Laitinen, M.P.E., Groome, N.P., Sawyer, H.R., Ritvos, O. 2003. Oocyte-derived growth factors and ovulation rate in sheep. Reprod. Suppl. 61:339-351. 
Medan, M.S., Watanabe, G., Sasaki, K., Nagura, Y., Sakaime, H., Fulita, M., Sharawy, S., Taya, K. 2003a. Ovarian and hormonal response of female goats to active immunization against inhibin. J. Endocrinol. 177:287-294.

Medan, M.S., Watanabe, G., Sasaki, K., Nagura, Y., Sakaime, H., Fulita, M., Sharawy, S., Taya, K. 2003 b. Effects of passive immunization of goats against inhibin on follicular development, hormone profile and ovulation rate. Reprod. 125:751-757.

Meisterling, E.M., Dailey, R.A. 1987. Use of concentrations of progesterone and estradiol-17 $\beta$ in milk in monitoring postpartum ovarian function in dairy cows. J Dairy Sci. 70:2154-2161.

Mermillod, P., Oussaid, B., Cognié, Y. 1999. Aspects of follicular and oocyte maturation that affect the developmental potential of embryos. J. Reprod. Fertil. Suppl. 54:449-460.

Meyer, H.H. 1985. Breed differences in ovulation rate and uterine efficiency and their contribution to fecundity. In: Genetics of Reproduction in Sheep. Eds. Land, R.B. and Robinson, D.W. Butterworths, London, pp. 185-191.

Midwest Plan Service. 1982. Sheep housing and equipment handbook. Third Edition. lowa State University, Ames, lowa, pp.88-89.

Minm, M., Baguisi, A., Boland, M.P., Roche, J.F. 1994. Association between the duration of dominance of the ovulatory follicle and pregnancy rate in beef heifers. J. Repro. Fertil. 102:123-130.

Mihm, M., Curran, N., Hyttle, P., Knight, P.G., Boland, M.P., Roche, J.F. 1999. Effect of dominant follicle persistence on follicular fluid oestradiol and inhibin and on oocyte maturation in heifers. J. Reprod. Fertil. 116:293-304.

Mihm, M., Good, T.E.M., Ireland, J.L.H., Ireland, J.J., Knight, P.G., Roche, J.F. 1997. Decline in serum follicle-stimulating hormone concentrations alters key intrafollicular growth factors involved in the selection of the dominant follicle in heifers. Biol. Reprod. 57:1328-1337.

Montgomery, G.W., McNatty, K.P., Davis, G.H. 1992. Physiology and molecular genetics of mutations that increase ovulation rate in sheep. Endocrine Rev. 13:309-328.

Moor, R.M., Lee, C., Dai, Y.F., Fulka Jr., J. 1996. Antral follicles confer developmental competence on oocytes. Zygote 4:289-293.

Moore, R.M., Rowson, L.E. 1960. Egg transfer in sheep. Factors affecting the survival and development of transferred eggs. J. Reprod. Fertil. 1:332-349. 
Morcan, L. 1973. Pregnancy detection in ewes-a new technique. N.Z. J. Agr. 126:15-21.

Nambo, Y., Kaneko, H., Nagata, S., Oikawa, M., Yoshihara, T., Nagamine, N., Watanabe, G., Taya, K. 1998. Effect of passive immunization against inhibin on FSH secretion, folliculogenesis and ovulation rate during the follicular phase of the estrous cycle in mares. Theriogenology 50:545-557.

Noel, B., Bister, J.L., Paquay, R. 1993. Ovarian follicular dynamics in Suffolk ewes at different periods of the year. J. Reprod. Fert. 99:695-700.

Nunemaker, C.S., DeFazio, R.A., Moenter, S.M. 2002. Estradiol-sensitive afferents modulate long-term episodic firing patterns of $\mathrm{GnRH}$ neurons. Endocrinology 143:2284-2292.

Odde, K.G. 1990. A review of synchronization of estrus in postpartum cattle. J. Anim. Sci. 76:1273-1279.

Oldham, C.M. 1980. Stimulation of ovulation in seasonally or lactationally anovular ewes by rams. Proc. Aust. Soc. Anim. Prod. 13:73-86.

Oldham, C.M., Cognié, Y. 1980. Do ewes continue to cycle after teasing? Proc. Aust. Soc. Anim. Prod. 13:82-85.

Oldham, C.M., Cognié, Y., Poindron, P., Gayerie, F. 1980. The influence of progesterone or FGA priming on the ovarian function of seasonally anovular ewes induced to ovulate by their re-introduction to rams and teasing. Proc. $9^{\text {th }}$. Int. Cong. Reprod. and Al. 3:50 (Abstract).

Oldham, C.M., Martin, G.B. 1978. Stimulation of seasonally anovular Merino ewes by rams. II. Premature regression of ram-induced corpora lutea. Anim. Reprod. Sci. 1:291-295.

Oldham, C.M., Pearce, D.T. 1983. Mechanism of the ram effect. Proc. Aust. Soc. Reprod. Biol. 15:72-75.

Oldham, C.M., Pearce, D.T., and Gray, S.J. 1985. Progesterone priming and age of ewe affect the life-span of corpora lutea induced in the seasonally anovulatory Merino ewe by the "ram effect." J. Reprod. Fert. 75:29-33.

Ortavant, R., Bocquier, J., Pelletier, J., Ravault, J.P., Thimonier, J., Volland-Nail, P. 1988. Seasonality of reproduction in sheep and its control by photoperiod. Aust. J. Biol. Sci. 41:69-85.

O'Shea, T., Cummins, L.J., Bindon, B.M., Findlay, J.K. 1982. Increased ovulation rate in ewes vaccinated with an inhibin enriched fraction from bovine follicular fluid. Proc. Aust. Soc. Reprod. Biol. 14:85 (Abstract). 
Oussaid, B., Mariana, J.C., Poulin, N., Fontaine, J., Lonergan, P., Beckers, J.F., Cogniè, Y. 1999. Reduction of the developmental competence of sheep oocytes by inhibition of LH pulses during the follicular phase with a $\mathrm{GnRH}$ antagonist. J. Reprod. Fert. 117:71-77.

Page, R.D., Butcher, R.L. 1982. Follicular and plasma patterns of steroids in young and old rats during normal and prolonged estrous cycles. Biol. Reprod. 27:383-392.

Page, R.D. Kirkpatrick-Keller, D., Butcher, R.L. 1983. Role of age and length of oestrous cycle in alteration of the oocyte and intrauterine environment in the rat. J. Reprod. Fert. 69:23-28.

Parsons, S.D., Hunter, G.L., Rayner, A.A. 1967. Use of probit analysis in a study of the effect of the ram on time of ovulation in the ewe. J. Reprod. Fert. 14:71-80.

Patterson, D.J., Kiracofe, G.H., Stevenson, J.S., Corah, L.R. 1989. Control of the bovine estrous cycle with melengestrol acetate (MGA): A review. J. Anim. Sci. 67:1895-1906.

Pearce, D.T., Gray, S.J., Oldham, C.M., Wilson, H.R. 1984. The use of intravaginal sponges and PMSG. Proc. Aust. Soc. Anim. Prod. 15:164-168.

Pearce, D.T., Martin, G.B., Oldham, C.M. 1985. Corpora lutea with a short lifespan induced by rams in seasonally anovulatory ewes are prevented by progesterone delaying the preovulatory surge of LH. J. Reprod. Fert. 75:79-84.

Pearce, D.T., Oldham, C.M. 1984. The ram effect, its mechanism and application to the management of sheep. In: Lindsay, D.R., Pearce, D.T. (Eds.)

Reproduction in Sheep.

Pearce, G. P., Oldham, C.M. 1988. Importance of non-olfactory ram stimuli in mediating ram-induced ovulation in the ewe. J. Reprod. Fert. 84:333-339.

Pelletier, J., Thimonier, J. 1972. Influence of fluorogestone acetate (FGA) on hypothalamo-hypophysial activity in anoestrous dry and lactating ewes. J. Reprod. Fert. 31:496-497.

Pelletier, J., Thimonier, J. 1973. Comparison of the induced preovulatory LH discharge in lactating and dry sheep during seasonal anoestrus. J. Reprod. Fert. 33:310-313.

Pelletier, J., Thimonier, J. 1975. Interactions between ovarian steroids or progestogens and LH release. Ann. Biol. Anim. Bioch. Biophys. 15:131-146.

Perkins, A., Fitzgerald, J.A. 1994. The behavioral component of the ram effect: The influence of ram sexual behavior on the induction of estrus anovulatory ewes. J. Anim. Sci. 72:51-55. 
Pierson, R.A., Ginther, O.J. 1988. Ultrasonic imaging of the ovaries and uterus in cattle. Theriogenology 29:21-37.

Piper, L.R., Bindon, B.M. 1981. Genetic segregation for fecundity and ovulation rate in Booiroola Merinos and their crosses. Proc. Workshop on Booroola Sheep. Christchurch, New Zealand.

Plant, J.W. 1980. Pregnancy diagnosis in sheep using a rectal probe. Vet. Rec. 106:305-306.

Plant, J.W., Tyrell, R.N. 1974. Evaluation of a rectal-abdominal palpation technique for pregnancy diagnosis in sheep. Aust. Vet. J. 50:178-179.

Pritchard, J.Y., Schrick, F.N., Inskeep, E.K. 1994. Relationship of pregnancy rate to peripheral concentrations of progesterone and estradiol in beef cows.

Theriogenology 42:247-259.

Pursley, J.R., Mee, M.O., Wiltbank, M.C. 1995. Synchronization of ovulation in dairy cows using PGF2 $\alpha$ and GnRH. Theriogenology 44:915-923.

Quinlivan, T.D., Martin, C.A., Taylor, W.B., Cairney, I.M. 1966. Estimates of preand perinatal mortality in the New Zealand Romney Marsh ewe. I. Pre- and perinatal mortality in those ewes that conceived to one service. J. Reprod. Fertil. 11:379-390.

Rajakoski, E. 1960. The ovarian follicular system in sexually mature heifers with special reference to seasonally, cyclical, and left-right variations. Acta.

Endocrinol. Suppl. 52:1-68.

Rajamahendran, R., Walton, J.S. 1990. Effect of treatment with estradiol valerate on endocrine changes and ovarian follicle populations in dairy cows. Theriogenology 33:441-452.

Ravindra, J.P., Rawlings, N.C., Evans, A.C.O., Adams, G.P. 1994.

Ultrasonographic study of ovarian follicular dynamics in ewes during the oestrous cycle. J. Repro. Fertil. 101:501-509.

Restall, B.J. 1971. The effect of lamb removal on reproductive activity in Dorset Horn x Merino ewes after lambing, J. Reprod. Fert. 24:145-146 (Abstract).

Restall, B.J., Griffiths, D.A. 1976. Assessment of reproductive wastage in sheep. 2. Interpretation of data concerning embryonic mortality. Aust. J. Exp. Agric. Anim. Husb. 16:336-343.

Restall, B.J., Radford, H.M. 1974. The induction of reproductive activity in lactating ewes with gonadotropin-releasing hormone $(\mathrm{GnRH})$. J. Reprod. Fertil. 36:475-476. 
Revah, I., Butler, W.R. 1996. Prolonged dominance of follicles reduces the viability of bovine oocytes. J. Repord. Fertil. 106:39-47

Rhind, S.M., Robinson, J.J., McDonald, I. 1980a. Relationships among uterine and placental factors in prolific ewes and their relevance to variations in fetal weight. Anim. Prod. 30:115-124.

Rhind, S.M., Robinson, J.J., Fraser, C. McHattie, I. 1980b. Ovulation and embryo survival rates and plasma progesterone concentrations of prolific ewes treated with PMSG. J. Reprod. Fertil. 58:139-144.

Richards, M.W., Geisert, R.D., Dawson, L.J., Rice, L.E. 1990. Pregnancy response after estrus synchronization of cyclic cows with or without a corpus luteum prior to breeding. Theriogenology 34:1185-1193.

Riches, J.H., Watson, R.H. 1954. The influence of the introduction of rams on the incidence of oestrus in Merino ewes. Aust. J. Agric. Res. 5:141-147.

Rivera, G.M., Alberio, R.H., Callejas, S.S., Doray, J.M. 1994. Advancement of ovulation and oestrus after temporary calf removal and FSH supplementation in postpartum beef cows. Anim. Reprod. Sci. 36:1-11.

Robinson, T.J. 1951. The control of fertility in sheep. Part II. The augmentation of fertility by gonadotrophin treatment of the ewe in the normal breeding season. J. Agric. Sci. Camb. 41:6-63.

Robinson, T.J., Moore, N.W., Lindsay, D.R., Fletcher, I.C., Salamon, S. 1970. Fertility following synchronization of oestrus in the sheep with intravaginal sponges. I. Effects of vaginal douche, supplementary steroids, time of insemination, and numbers and dilution of spermatozoa. Aust. J. Agric. Res. 21:767-781.

Robinson, T.J., Quinlivan, T.D., Baxter, C. 1968. The relationship between dose of progestagen and method of preparation of intravaginal sponges on their effectiveness for control of ovulation in the ewe. J. Reprod. Fertil. 17:471-483.

Robinson, T.J., Smith, J.F. 1967. The evaluation of SC-9880-impregnated intravaginal sponges used with or without PMS for the advancement of the breeding season of British Breed ewes. Robinson, T.J. The control of the ovarian cycle in sheep. $1^{\text {st }}[\mathrm{X}]$, pp. 144-157. Sydney, Sydney University Press.

Roche, J.F., Mihm, M., Diskin, M.G. 1997. Physiology and practice of induction and control of oestrus in cattle. The Bov. Pract. 31:4-10.

Romano, J.E., Christians, C.J., Crabo, B.G. 1998. Early pregnancy detection by transrectal ultrasonography in Suffolk ewes. Minnesota Sheep Research Report 1998:83-86. 
Rosas, C.A., Albeiro, R.H., Baranao, J.L., Agüero, A., Chaves, M.G. 1998. Evaluation of two treatments in superovulation of mares. Theriogenology 49:1257-1264.

Rozell, T.G., Keisler, D.H. 1990. Effects of oestradiol on LH, FSH and prolactin in ovariectomized ewes. J. Reprod. Fertil. 88:645-651.

Sanchez, T., Wehrman, M.E., Bergfeld, E.G., Peters, K.E., Kojima, F.N., Cupp, A.S., Mariscal, V., Kittok, R.J., Rasby, R.J., Kinder, J.E. 1993. Pregnancy rate is greater when the corpus luteum is present during the period of progestin treatment to synchronize time of estrus in cows and heifers. Biol. Reprod. 49:1102-1107.

Sanchez, T., Wehrman, M.E., Kojima, F.N., Cupp, A.S., Bergfeld, E.G., Peters, K.E., Mariscal, V., Kittok, R.J., Kinder, J.E. 1995. Dosage of the synthetic progestin, norgestomet, influences luteinizing hormone pulse frequency and endogenous secretion of 17ß-estradiol in heifers. Biol. Reprod. 52:464-469.

Sangsritavong, S., Combs, D.K., Sartori, R., Armentano, L.E., Wiltbank, M.C. 2002. High feed intake increases liver blood flow and metabolism of progesterone and estradiol-17 $\beta$ in dairy cattle. J. Dairy Sci. 85:2831-2842.

Savio, J.D., Keenan, L., Boland, M.P., Roche, J.F. 1988. Pattern of growth of dominant follicles during the oestrous cycle of heifers. J. Reprod. Fertil. 83:663671.

Scaramuzzi, R.J., Adams, N.R., Baird, D.T., Campbell, B.K., Downing, J.A., Findlay, J.K., Henderson, K.M., Martin, G.B., McNatty, K.P., McNeilly, A.S., Tsonis, C.G. 1993. A model for follicle selection and the determination of ovulation rate in the ewe. Reprod. Fert. Dev. 5:459-478.

Scaramuzzi, R.J., Radford, H.M. 1983. Factors regulating ovulation rate in the ewe. J Reprod. Fert. 69:353-367.

Schinckel, P.G. 1954a. The effect of the presence of the ram on the ovarian activity of the ewe. Aust. J. Agric. Res. 5:465-469.

Schinckel, P.G. 1954b. The effect of the ram on the incidence of oestrus in ewes. Aust. Vet. J. 30:189-195.

Schmitt, E.J.P., Drost, M., Diaz, T., Roomes, C., Thatcher, W.W. 1996. Effect of a gonadotropin-releasing hormone agonist on follicle recruitment and pregnancy rate in cattle. J. Anim. Sci. 74:154-161.

Schrick, F.N., Inskeep, E.K. 1993. Determination of early pregnancy in ewes utilizing transrectal ultrasonography. Theriogenology 40:295-306. 
Schrick, F.N., Surface, R.A., Pritchard, J.Y., Dailey, R.A., Townsend, E.C., Inskeep, E.K. 1993. Ovarian structures during the estrous cycle and early pregnancy in ewes. Biol. Reprod. 49:1133-1140.

Sheffel, C.E., Pratt, B.R., Ferrell, W.L., Inskeep, E.K. 1982. Induced corpora lutea in the postpartum beef cow. II. Effects of treatment with progesogen and gonadotropins. J. Anim. Sci. 54:830-836.

Shevah, Y., Black, W.J.M., Carr, W.R., Land, R.B. 1974. The effect of lactation on the resumption of reproductive activity and the preovulatory release of $\mathrm{LH}$ in Finn x Dorset ewes. J. Reprod. Fert. 38:369-378.

Shively, T.E., Williams, G.L. 1989. Patterns of luteinizing hormone release and ovulation frequency in suckled anestrous beef cows following varying intervals of temporary weaning. Domes. Anim. Endocrinol. 6:379-387.

Short, R.E., Bellows, R.A., Moody, E.L., Howland, B.E. 1972. Effects of suckling and mastectomy on bovine postpartum reproduction. J. Anim. Sci. 34:70-78.

Short, R.E., Bellows, R.A., Staigmiller, R.B., Berardinelli, J.G., Custer, E.E. 1990. Physiological mechanisms controlling anestrus and infertility in postpartum beef cattle. J. Anim. Sci. 68:799-816.

Signoret, J.P. 1975. Influence of the presence of rams on the luteinizing hormone surge after oestradiol benzoate injection in ovariectomized ewes. J. Endocr. 64:589-590.

Signoret, J.P. 1976. Chemical communication and reproduction in domestic animals. In: R.L. Doty (Ed.) Mammalian Olfaction, Reproductive Processes and Behavior. pp. 243-256. Academic Press, New York.

Sirois, J., Fortune, J.E. 1988. Ovarian follicular dynamics during the estrous cycle in heifers monitored by real-time ultrasonography. Biol. Reprod. 39:308-317.

Sirois, J., Fortune, J.E. 1990. Lengthening the bovine estrous cycle with low levels of progesterone: A model for studying follicular dominance. Endocrinology 127:916-925.

Smith, M.F., Burrell, W.C., Shipp, L.D., Sprott, L.R., Songster, W.N., Wiltbank, J.N. 1979. Hormone treatments and use of calf removal in postpartum beef cows. J. Anim. Sci. 48:1285-1294.

Smith, M.W., Stevenson, J.S. 1995. Fate of the dominant follicle, embryonic survival, and pregnancy rates in dairy cattle treated with prostaglandin $F_{2 \alpha}$ and progestins in the absence or presence of a functional corpus luteum. J. Anim. Sci. 73:3743-3751. 
Souza, C.J.H, Campbell, B.K., Webb, R., Baird, D.T. 1997. Secretion of inhibin A and follicular dynamics throughout the estrous cycle in the sheep with and without the Booroola gene $\left(\mathrm{Fec}^{\mathrm{B}}\right)$. Endocrinology 138:5333-5340.

Stafford, K.J., Chambers, J.P., Sylvester, S.P., Kenyon, P.R., Morris, S.T., Lizarraga, I., de Nicolo, G. 2006. Stress caused by laproscopy in sheep and its alleviation. N.Z. Vet. J. 54:109-113.

Taft, R.A. 1999. Oocyte morphology and estrogen concentrations following a reduction in progesterone in beef cattle. Dissertation, West Virginia University, Morgantown, WV.

Taft, R., Ahmad, N., Inskeep, E.K. 1996. Exogenous pulses of luteinizing hormone cause persistence of the largest bovine ovarian follicle. J. Anim. Sci. 74:2958-2991.

Tainturier, D., Lijour, L., Chaari, M., Sardjana, K.W., Lenet, J. 1983. Diagnostic de la gestation chez la brebis par échotomographie. Rev. Med. Vet. 134:523526.

Tervit, H.R., Havik, P.G., Smith, J.F. 1977. Effect of breed of ram on the onset of the breeding season in Romney ewes. Proc. N.Z. Soc. Anim. Prod. 37:142-148.

Thatcher, W.W., Macmillan, K.L., Hansen, P.J., Drost, M. 1989. Concepts for regulation of corpus luteum function by the conceptus and ovarian follicles to improve fertility. Theriogenology 31:149-164.

Thimonier, J., Bosc, M., Djiane, J., Martal, J., Terqui, M. 1977. Hormonal diagnosis of pregnancy and number of fetuses in sheep and goats. In: Chairman Terrill (Ed.) Proc. Symp. on Management of Reproduction in Sheep and Goats. $p$ 78. University of Wisconsin, Madison.

Thimonier, J., Pelletier, J. 1971. Difference génétique dans la décharge ovulante (LH) chez les brebis de race lle de France: relation avec le nombre d'ovulation. Ann. Biol. Anim. Bioch. Biophys. 11:559-567.

Thomas, G.B., Pearce, D.T., Oldham, C.M., Martin, G.B. 1984. Reduction in pulse frequency by steroids: differences between Merino and Suffolk ewes. Proc. Aust. Soc. Reprod. Biol. 16:95.

Townson, D.H., Tsang, P.C.W., Butler, W.R., Frajblat, M., Griel Jr., L.C., Johnson, C.J., Milvae, R.A., Niksic, G.M., Pate, J.L. 2002. Relationship of fertility to ovarian follicular waves before breeding in dairy cows. J. Anim. Sci. 80:10531058.

Trapp, M.J., Slyter, A.L. 1983. Pregnancy diagnosis in the ewe. J. Anim. Sci. 57:1-5. 
Tsonis, C.G., Cahill, L.P., Carson, R.S., Findlay, J.K. 1984. Identification at the onset of luteolysis of follicles capable of ovulation in the ewe. J. Repro. Fertil. 70:609-614.

Turner, C.B., Hindson, J.C. 1975. An assessment of a method of manual pregnancy diagnosis in the ewe. Vet. Rec. 96:56-58.

Twagiramungu, H., Guilbault, L.A., Proulx, J., Dufour, J.J. 1992. Synchronization of estrus in beef cattle with two injections of Buserelin and prostaglandin. Theriogenology 38:1131-1144.

Twagiramungu, H., Guilbault, L.A., Dufour, J.J. 1995. Synchronization of ovarian follicular waves with a gonadotropin-releasing hormone agonist to increase the precision of estrus in cattle: A review. J. Anim. Sci. 73:3141-3151.

Twagiramungu, H., Guilbault, L.A., Proulx, J.G., Dufour, J.J. 1994. Influence of corpus luteum and induced ovulation on ovarian follicular dynamics in postpartum cyclic cows treated with buserelin and cloprostenol. J. Anim. Sci. 72:1796-1805.

Tyrrell, R.N., Plant, J.W. 1979. Rectal damage in ewes following pregnancy diagnosis by rectal-abdominal palpation. J. Anim. Sci. 48:348-350.

Ulberg, L.C., Christian, R.E., Casida, L.E. 1951. Ovarian response of heifers to progesterone injections. J. Anim. Sci. 10:752-759.

Underwood, E.J., Shier, F.L., Davenport, N. 1944. Studies in sheep husbandry in Western Australia. V. The breeding season of merinos, crossbreeds and British breed ewes in the agricultural districts of WA. J. Dep. Agric. West. Austr. 21:135143.

Van Cleeff, J., Karsch, F.J., Padmanabhan, V. 1998. Characterization of the endocrine events during the periestrous period in sheep after estrous synchronization with controlled internal drug release (CIDR) device. Dom. Anim. Endo. 15:23-34.

Van de Leemput, E. E., Van der Shams, J.M., Vos, P.L.A.M., Bevers, M.M., Dieleman, S.J. 1998. Follicular function as defined by estradiol-17 $\beta$ production determines in vitro developmental capacity of bovine oocytes derived from preovulatory-sized follicles. Theriogenology 31:555-564.

Viñoles, C., Meikle, A., Forsberg, M., Rubianes, E. 1999. The effect of subluteal levels of exogenous progesterone on follicular dynamics and endocrine patterns during the early luteal phase of the ewe. Theriogenology 51:1351-1361.

Viñoles, C., Forsberg, M., Banchero, G., Rubianes, E. 2001. Effect of long-term and short-term progestagen treatment on follicular development and pregnancy rate in cyclic ewes. Theriogenology 55:993-1004. 
Walkden-Brown, S.W., Restall, B.J., Henniawati. 1993a. The male effect in the Australian Cashmere goat. 2. Role of olfactory cues from the male. Anim. Reprod. Sci. 32:55-67.

Walkden-Brown, S.W., Restall, B.J., Henniawati. 1993b. The male effect in the Australian Cashmere goat. 3. Enhancement with buck nutrition and use of oestrous females. Anim. Reprod. Sci. 32:69-84.

Warren Jr., J.E., Kiesling, D.O., Akinbami, M.A., Price, E.A., Meredith, S. 1989. Conception rates in early postpartum ewes bred naturally or by intrauterine insemination. J. Anim. Sci. 67:2056-2059.

Watson, R.H., Radford, H.M. 1960. Influence of rams on the onset of oestrous in Merino ewes in the spring. Aust. J. Agric. Res. 11:65-71.

Wheaton, J.E., Recabarren, S.E., Mullett, M.A. 1982. GnRH-FSH and LH doseresponse relationships in anestrous sheep and effects of estradiol-17 beta and progesterone pretreatment. J. Anim. Sci. 55:384-390.

Whisnant, C.S., Inskeep, E.K. 1992. Biological aspects of out-of-season breeding in the ewe. lowa State University, lowa State University Extension. Out of Season Breeding Symposium. pp. 1-24.

White, I.R., Russel, A.J.F. 1984. Determination of fetal numbers in sheep by real time ultrasonic scanning. In Pract. 6:200-202.

Whiteman, J.V., Zollinger, W.A., and Thrift, F.A. 1972. Postpartum mating performance of ewes involved in a twice-yearly lambing program. J. Anim. Sci. 35:836-842.

Williams, G.L. 1990. Suckling as a regulator of postpartum rebreeding in cattle: A review. J. Anim. Sci. 68:831-852.

Wiltbank, M.C. 1997. How information on hormonal regulation of the ovary has improved understanding of timed breeding programs. Proc. Ann. Meeting Soc. Therio., Montreal, Quèbec. pp.83-97.

Wishart, D.F. 1977. Synchronization of oestrus in heifers using steroid (SC 5914, SC 9880 and SC 21009) treatment for 21 days: the effect of treatment on the ovum collection and fertilization rate and development of the early embryo.

Theriogenology. 8:249-269.

Wood, S.C., Glencross, R.G., Bleach, E.C., Lovell, R., Beard, A.J., Knight, P.G. 1993. The ability of steroid-free bovine follicular fluid to suppress FSH secretion and delay ovulation persists in heifers actively immunized against inhibin. J. Endocrinol. 136:137-148. 
Wright, I.A., Rhind, S.M., Russel, A.J.F., Whyte, T.K., McBean, A.J., McMillen, S.R. 1987. Effects of body condition, food intake and temporary calf separation on the duration of the postpartum anoestrus period and associated $\mathrm{LH}, \mathrm{FSH}$ and prolactin concentrations in beef cows. Anim. Prod. 54:143-146.

Yelich, J.V., Holland, M.D., Schutz, D.N., Odde, K.G. 1995. Synchronization of estrus in suckled postpartum beef cows with melengestrol acetate, 48-hour calf removal and $\mathrm{PGF}_{2 \alpha}$. Theriogenology 43:401-410.

Ying, S.Y., Becker, A., Ling, N., Uneo, N., Guilemin, R. 1986. Inhibin and type Beta transforming growth factor TGF- $\beta$ have opposite modulating effects on the follicle stimulating hormone (FSH)-induced aromatase activity of cultured rat granulose cells. Biochem. Biophys. Res. Comm. 136:969-975. 